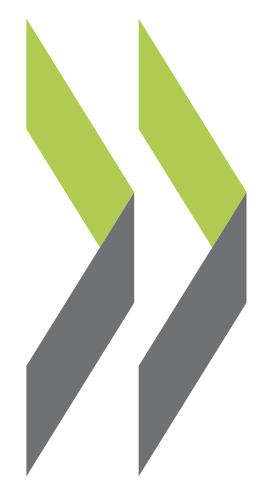

OECD Social, Employment and Migration Working Papers No. 64

\title{
A Review of Studies on the Distributional Impact of Consumption Taxes in OECD Countries
} Neil Warren 


\section{A Review of Studies on the Distributional Impact of} Consumption Taxes in OECD Countries

Neil Warren

64 
Organisation de Coopération et de Développement Économiques

Organisation for Economic Co-operation and Development

26-Jun-2008

DIRECTORATE FOR EMPLOYMENT, LABOUR AND SOCIAL AFFAIRS

English text only EMPLOYMENT, LABOUR AND SOCIAL AFFAIRS COMMITTEE

OECD SOCIAL, EMPLOYMENT AND MIGRATION WORKING PAPERS NO. 64

\section{A REVIEW OF STUDIES ON THE DISTRIBUTIONAL IMPACT OF CONSUMPTION TAXES IN OECD COUNTRIES}

Neil Warren

JEL Classification: D31; H23

All Social, Employment and Migration Working Papers are now available through OECD's Internet website at http://www.oecd.org/els

JT03248368

Document complet disponible sur OLIS dans son format d'origine

Complete document available on OLIS in its original format 


\title{
DIRECTORATE FOR EMPLOYMENT, LABOUR AND SOCIAL AFFAIRS
}

http://www.oecd.org/els

\section{OECD SOCIAL, EMPLOYMENT AND MIGRATION WORKING PAPERS}

\author{
http://www.oecd.org/els/workingpapers
}

This series is designed to make available to a wider readership selected labour market, social policy and migration studies prepared for use within the OECD. Authorship is usually collective, but principal writers are named. The papers are generally available only in their original language - English or French - with a summary in the other.

Comment on the series is welcome, and should be sent to the Directorate for Employment, Labour and Social Affairs, 2, rue André-Pascal, 75775 PARIS CEDEX 16, France.

The opinions expressed and arguments employed here are the responsibility of the author(s) and do not necessarily reflect those of the OECD

\section{Applications for permission to reproduce or translate all or part of this material should be made to:}

\author{
Head of Publications Service \\ OECD \\ 2, rue André-Pascal \\ 75775 Paris, CEDEX 16 \\ France
}

Copyright OECD 2008 


\section{ACKNOWLEDGEMENTS ${ }^{1}$}

I would like to thank Marco Mira d'Ercole and his colleagues in the Directorate for Employment, Labour and Social Affairs at the Organisation for Economic Co-operation and Development for making available to this study the data used in their own earlier studies as well as their contribution through comment and feedback on drafts of the Working Paper. I would particularly like to thank Marco for his encouragement and enthusiasm for this project and our shared view about the importance of all fiscal incidence studies including consumption taxes in their analysis. Thanks also for various comments on this paper provided by members of the Working Party on Social Policy of the OECD Employment, Labour and Social Affairs Committee and the Working Party on Tax Policy Analysis and Tax Statistics of the OECD Committee on Fiscal Affairs.

1. This paper has been prepared by Neil Warren, Australian School of Taxation, University of New South Wales, Sydney 2052, Australia (email: n.warren@unsw.edu.au). This paper was commissioned by the OECD in the context of its work on the "distribution of resources". 


\section{EXECUTIVE SUMMARY}

Consumption taxes are only rarely assessed for their impact on the economic well-being of individuals. This paper reviews various studies on this issue. It first describes the large differences in the size and structure of these taxes among OECD countries, and then reviews the types of assumptions that are typically made when estimating the redistributive impact of these taxes. Based on this review, the paper advocates the wider adoption of the methodology that is currently adopted by government statisticians in Australia, Canada and the United Kingdom - based on input-output tables and on the modelling of a large part of the consumption taxes levied on various types of final expenditures and production inputs. The paper argues that, beyond methodological differences, all studies agree that consumption taxes have a significant regressive impact on the distribution of household disposable income. Illustrative simulations based on applying the detailed findings on the incidence of consumption tax in one country (Australia) to the tax structure and income distribution of other OECD countries suggests that omission of consumption taxes affects estimates of the overall size of the redistribution achieved through the tax system and of how this differ across countries and evolves over time.

\section{RÉSUMÉ}

Les impôts à la consommation sont rarement évalués pour leur incidence sur le bien-être économique des individus. Ce document se penche sur cette question. D'abord, il présente les grandes différences dans la taille et la structure de ces impôts dans les pays de l'OCDE. Puis, il examine les hypothèses qui sont typiquement faites pour estimer leur impact redistributif. Sur la base de cet examen, le document prône l'adoption plus large de la méthodologie actuellement adoptée par la Statistique publique en Australie, au Canada et au Royaume-Uni - une méthodologie basée sur des tableaux entrées-sorties et qui considère la plus grande partie des impôts à la consommation prélevés tant sur les dépenses finales que sur les facteurs de production. Le document montre qu'au-delà des différences méthodologiques, toutes les études conviennent que les impôts sur la consommation ont une incidence régressive significative sur la distribution du revenu disponible des ménages. Des simulations indicatives - basées sur l'application des résultats sur l'incidence des impôts à la consommation dans un pays (l'Australie) sur la structure des impôts et la distribution du revenu des autres pays de l'OCDE - montrent que d'ignorer ces impôts affecte toutes mesures de redistribution opérée par le système fiscal et que ces effets varient d'un pays à l'autre et dans le temps. 


\section{TABLE OF CONTENTS}

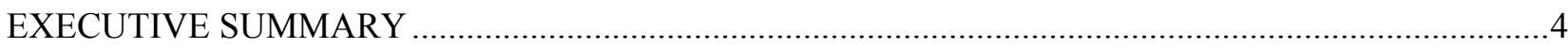

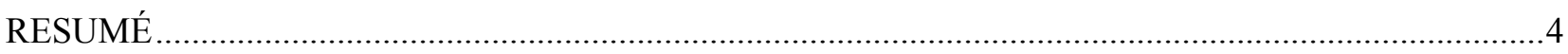

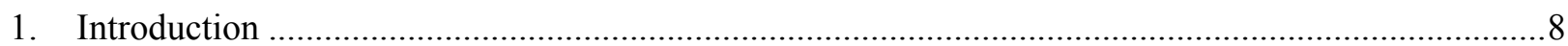

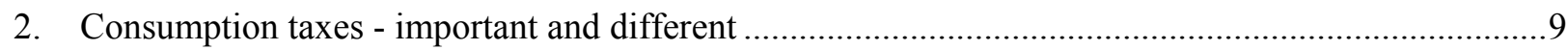

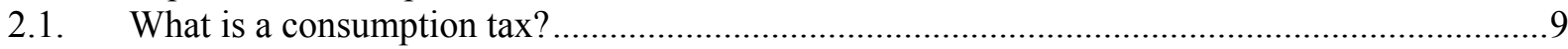

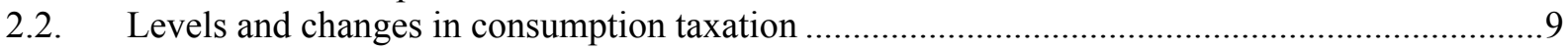

3. Modelling consumption tax incidence: theory and practice …......................................................12

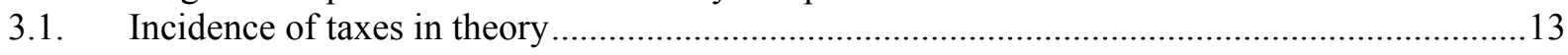

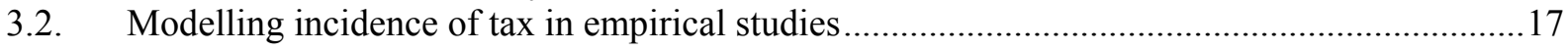

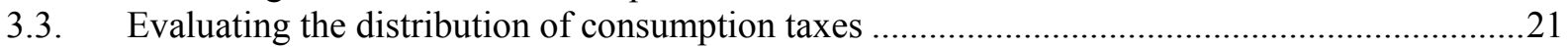

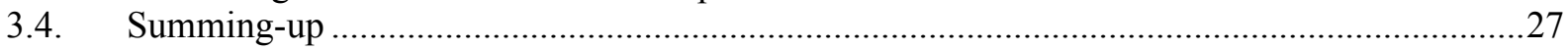

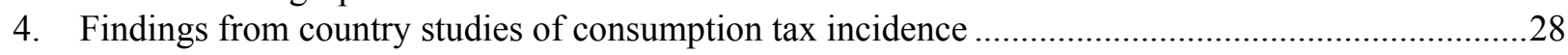

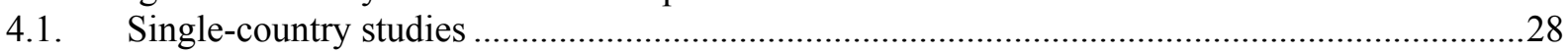

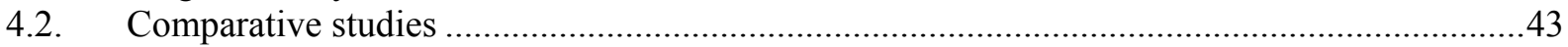

5. Controlled hypothetical estimates of consumption tax incidence in OECD countries .....................50

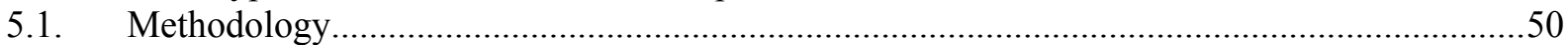

5.2. What if consumption taxes were included in a broader measure of household

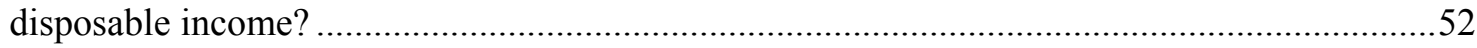

5.3. What if consumption taxes fund selected government transfers? .........................................57

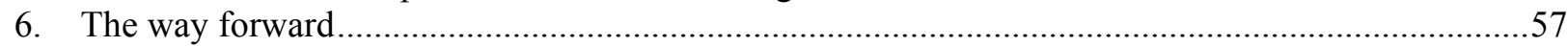

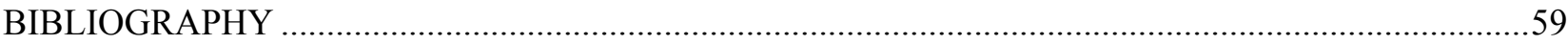

\section{Tables}

Table 1. An overview of studies on the incidence of consumption taxes.........................................30

Table 2. The effects of taxes and benefits on household income in the United Kingdom, 2005-06.

Table 3. The impact of the tax system on income distribution in Australia .........................................37

Table 4. The impact of including in-kind transfers funded by consumption taxes on the distribution of household income: evidence from LIS .......................................................44

Table 5. Total revenue from consumption taxes in 12 EU countries, 1998) ....................................45

Table 6. Average effective tax rates on VAT and excise duties based on EUROMOD....................47

Table 7. Progressivity of indirect tax compared to other instruments based on EUROMOD .............48

Table 8. A comparison of estimates of the incidence of taxes based on different models for Belgium.

Table 9. Redistributive effects of different government policies in selected OECD countries.............56 


\section{Figures}

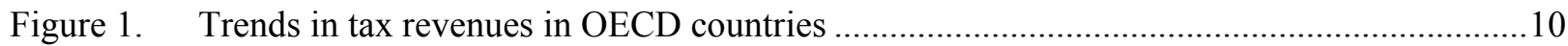

Figure 2. Level of tax revenues across OECD countries ..............................................................11

Figure 3. Composition of tax revenues across OECD countries........................................................11

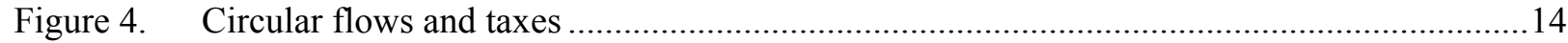

Figure 5. Alternative ways of allocating consumption taxes to household final consumers ................18

Figure 6. Modelling of consumption taxes under the assumption of full forward-shifting .................21

Figure 7. Different income concepts and stages of redistribution ...................................................23

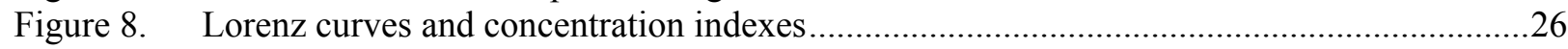

Figure 9. Consumption tax incidence in Australia, Canada, Ireland and the United Kingdom..............33

Figure 10. The incidence of consumption taxes in the United States ..................................................41

Figure 11. Measures of the incidence of consumption taxes in selected European

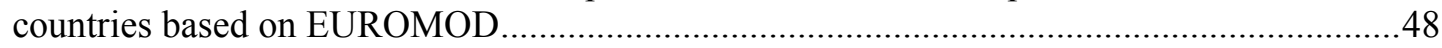

Figure 12. The distributive profile of consumption taxes in Belgium based on different models and definitions of household income.......................................................................49

Figure 13. A comparison of the incidence of consumption taxes in Australia and the United Kingdom, 2001-02.....

Figure 14. The impact of consumption taxes on income inequality in selected OECD countries.

Figure 15. Changes in ratios of relative economic well-being due to consumption taxes ........................54

Figure 16. The impact on income inequality of consumption taxes and in-kind public services in selected OECD countries .

\section{Boxes}

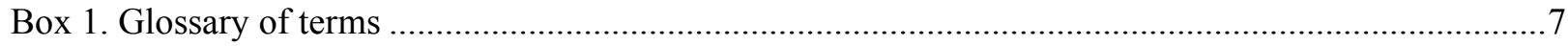

Box 2. A simple graphical illustration of the effect of an excise duty on demand and supply of a given commodity 


\section{Box 1. Glossary of terms}

ABS Australian Bureau of Statistics <www.abs.gov.au>

ATR Average Tax Rate

CBOCongressional Budget Office <www.cbo.gov>

CGE Computational General Equilibrium Model

CT Consumption tax

DWLDeadweight loss

DY Disposable income

EUROMOD multi-country Europe-wide tax-benefit model <www.iser.essex.ac.uk/msu/emod/> GDP Gross Domestic Product

GE General Equilibrium

GST Goods and Services Tax

HES Household Expenditure Survey

HMRC HM Revenue and Customs <www.hmrc.gov.uk>

IFS Institute for Fiscal Studies <www.ifs.org.uk>

IRD Inland Revenue Department (New Zealand) <www.ird.govt.nz>

IRS Internal Revenue Service (US) <www.ird.gov>

ITEPInstitute on Taxation and Economic Policy <www.itepnet.org>

LIS Luxembourg Income Study <www.lisproject.org>

MTRMarginal Tax Rate

OECD Organisation for Economic Cooperation and Development <www.oecd.org>

ONSOffice for National Statistics <www.statistics.gov.uk>

OTA Office of Tax Analysis <http://www.treas.gov/offices/tax-policy/library/otapapers/>

PIT Personal income tax

SPITSimulation program for indirect taxes (IFS)

SPSD/M Social Policy Simulation Database and Model <www.statcan.ca/english/spsd/>

STINMOD NATSEM Australian tax and benefit model <www.canberra.edu.au/centres/natsem/>

TF Tax Foundation <www.taxfoundation.org >

VAT Value Added Tax 


\section{Introduction}

1. Studies into the distributional impact of all government taxes on individuals have a long history. Gillespie (1965) and Dodge (1975) undertook early studies in Canada and Pechman and Okner (1974) and Reynolds and Smolensky (1977a, 1977b) in the United States. Bentley, Collins and Drane (1974) and Warren (1979) estimated tax incidence in Australia while the UK Central Statistical Office (now Office of National Statistics) produced some of the earliest official estimates of tax incidence in the $1950 \mathrm{~s}^{2}$

2. Despite these early advances in modelling all taxes, comprehensive studies remain relatively few, and most studies limit their attention to the distributional impact of personal income taxes and social security levies (as well as social welfare benefits). Readily available data on the incomes of individuals and households, combined with an ability to draw a direct link between the personal income tax rate schedule and its impact on persons has meant that analysis of the distributive impact of personal income tax and public cash benefits is now commonplace. When combined with research on labour supply, such studies allow a better understanding of how such taxes impact on individual behaviour. ${ }^{3}$

3. In fact, almost all reforms to government personal income tax and social welfare policies are now accompanied by detailed information on their impact on various household types. ${ }^{4}$ By contrast, such assessments remain an exception in the case of consumption taxes. ${ }^{5}$ This position cannot be explained by a lack of academic research into consumption tax incidence, as witnessed by the numerous studies undertaken over the past decade, but rather reflect two main factors. ${ }^{6}$ The first is that, unlike the broad agreement on the conceptual approach to be used when estimating the incidence of personal income tax, no such agreement exists about how to model the incidence of consumption tax on individuals. The second factor, which compounds the conceptual problem, is the data demands of such studies which are not readily met. The result of this situation is that very different approaches have been used to model the incidence of consumption tax on individuals. This paper takes stock of the progress, past and present, into the distributional impact of consumption taxes, with an aim of better understanding how such studies are undertaken, what have been their findings and what benefits might be derived from including consumption taxes into an inter-temporal and cross-country comparison of the impact of government on individuals. This report reviews the literature on consumption incidence with the objective of providing insight into:

2. The Australian Bureau of Statistics (ABS) replicated the basic UK methodology in 1987 for the year 1984 and has prepared such studies since for the years 1988-89, 1993-94, 1998-99 and 2003-04. For the most recent studies see <http://www.abs.gov.au/AUSSTATS/abs@.nsf/DetailsPage/6537.0200304 ? OpenDocument $>$ and $<$ http://www.statistics.gov.uk/cci/article.asp?ID=1804\&Pos=1\&ColRank=1\&Rank=1>

3. See for example the labour supply research at the IFS $<$ http://www.ifs.org.uk/publications.php?heading_id=10>:

4. However, such estimates rarely incorporate labour supply responses, including only a static snapshot of the pre- and post-reform situations (i.e. assuming no responses by individuals).

5. Detailed modelling of the distributional impact of consumption tax reforms are however implemented in some countries, such as Australia. See Chapter 5 of the Australian Government document outlining the impact of the then-proposed 10\% GST, Tax Reform: Not a New Tax, A New Tax System (1998) accessible from <http:/www.treasury.gov.au/contentitem.asp?pageId=\&ContentID=167>

6. See. Barrett and Wall (2005), Creedy (2001, 2002), Decoster (1995), Decoster, De Swerdt and Verbist (2007), Decoster, Schokkaert and Van Camp (1997), Decoster and Van Camp (2001), Garfinkel, Rainwater and Smeeding (2006), Harding, Lloyd and Warren (2004, 2006, 2007), Kaplanoglou and Newbery (2003), Kaplanoglou (2004), Liberati (2001), Madden (1995), O’Donoghue, Baldini and Mantovani (2004), Newbery (1995), and Tsakloglou and Mitrakos (1998). 
- $\quad$ Conceptual and data issues confronting such studies (Section 3);

- $\quad$ Findings from past studies (Section 4); and

- $\quad$ Illustrations of the potential impact of including consumption taxes into a more comprehensive assessment of income distribution across countries (Section 5).

4. The ultimate objective of this review is to provide a better understanding of the impact of consumption taxes on the economic well-being of individuals.

\section{Consumption taxes - important and different}

\subsection{What is a consumption tax?}

5. How best to classify the many different taxes imposed by governments has been the subject of considerable discussion. Traditionally, a distinction was drawn between an indirect tax, defined as a tax collected by persons or organisations but shifted on to others, and a direct tax, i.e. those paid directly to the government by the persons or organisations from whom it is collected. Using such a classification, personal income taxes, social security contributions on employees, corporate income taxes and capital transfer taxes were defined as direct taxes, and consumption taxes, excise duties and employer social security contributions as indirect taxes. However, such an approach is problematic as the classification is not independent of the discussion over the shifting of the tax which is concerned with how the economic (or final) incidence of the tax differs from its statutory (or legal) incidence.

6. In response, there has been a move away from this direct/indirect tax classification to one focusing on providing a "coherent framework for recording and presenting the main flows relating respectively to production, consumption, accumulation and external transactions of a given economic area, usually a country or a major region within a country" (OECD 2006, p. 299). This classification is designed to "provide the maximum disaggregation of statistical data on what are generally regarded as taxes by tax administrations'. (OECD 2006, p. 300).

\subsection{Levels and changes in consumption taxation}

7. Figure 1 presents data on the importance of the main categories of taxes across all OECD countries, where such importance is assessed relative to both total taxation and as a share of GDP. Both the level and mix of tax revenues vary widely over time, even for similar categories of taxes. In the case of consumption-based taxes, while their contribution to total tax revenue has decreased, on average, from $37 \%$ to $30 \%$ over the period 1965 to 2004 , this has come about as a result of a significant change in their mix. There has been an increase from $15 \%$ to $19 \%$ in the share of general consumption taxes (e.g. VAT/GST) and a fall from $22 \%$ to $11 \%$ for taxes on specific goods and services (such as excise on petrol, tobacco, alcohol). Further, despite the falling contribution of total consumption taxes to total tax revenue between 1965 and 2004, their size relative to GDP has risen from $9.6 \%$ to $10.8 \%$. This is also at a time when the mix of income-based taxes has changed away from personal income taxes towards social security contributions, especially on employers. ${ }^{7}$ Because of these trends, any study of changes in the distributional

7. In the case of taxes on personal income, there were equally significant changes in the mix. Between 1965 and 2004, the personal income tax as a proportion of GDP fell, especially in recent years, primarily due to cuts in the personal income tax rates while employee social security contributions initially increased but have stabilized over the past decade. This is all at a time when employer social security contributions increased significantly, both as a proportion of GDP and in contribution to total taxes. 
impact of government on individuals which omits consumption taxes or social security contributions will lead to biased results.

Figure 1. Trends in tax revenues in OECD Countries

Average of 30 OECD countries

a. Percentage share of total tax revenues

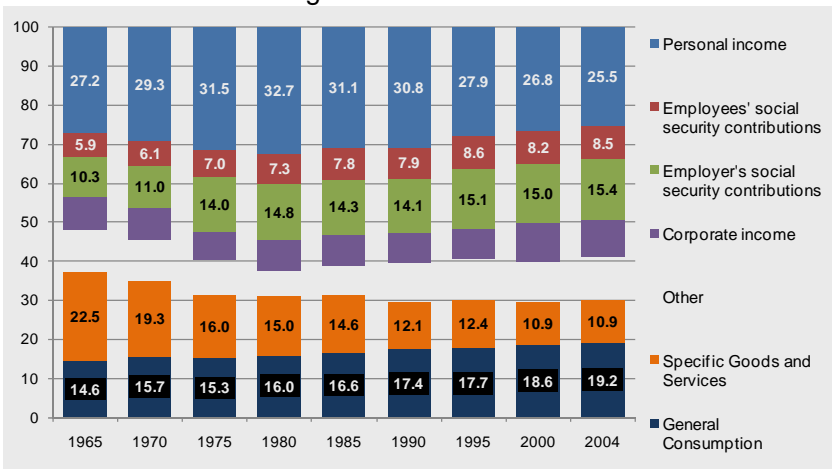

b. Percentage share of GDP

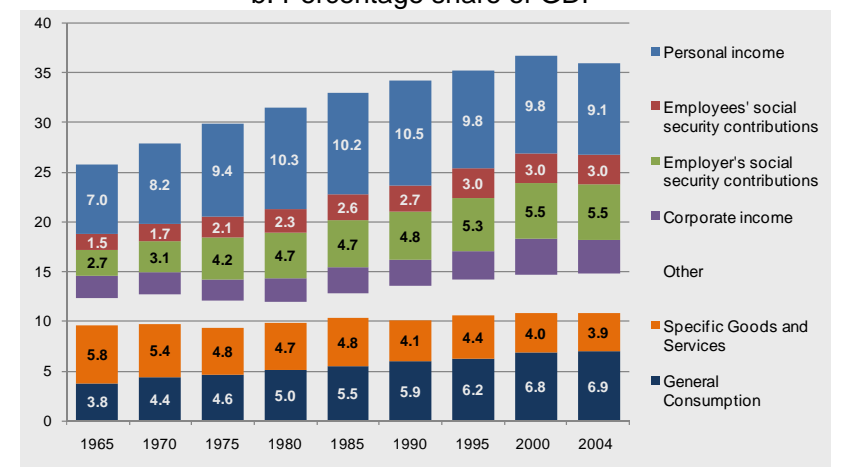

Source: OECD Revenue Statistics 1965-2005.

8. Figure 2 presents data on tax to GDP ratios in all OECD countries in 2004, with countries ranked by the level of their taxes on goods and services (OECD Tax Classification 5000). What is apparent is that while personal income and social security taxes on employees are a significant proportion of GDP, they are just part of the total tax burden. For many countries high consumption taxes are accompanied by low personal income taxes and vice versa. In 11 countries taxes on goods and services contributed more to total tax revenue than taxes on personal income and social security levies on employees combined; in 20 cases, taxes on all goods and services exceeded taxes on personal income while in 10 taxes on general consumption exceeded those on personal income. These differences imply that any inter-country comparison of the impact of government taxes on individuals which omits consumption taxes will yield biased results because of both the different level (Figure 1) and mix (Figures 2 and 3) of these taxes. Even including only general consumption taxes (such as a VAT/GST) will not fully address this problem because of cross-country differences in composition of all consumption taxes (Figure 1) and in their size.

9. The case for including consumption taxes along with personal income tax and employee social security contributions taxes in any inter-temporal or cross-country comparisons of the impact of government tax policies is therefore clear. Even if the contribution and composition of consumption taxes remained similar and unchanged over time and between countries, studies focusing only on personal income tax and employee social security contributions will provide a partial assessment because the incidence of these two groups of taxes are significantly different. 
Figure 2. Level of tax revenues across OECD countries

Taxes in percentage of GDP in 2004

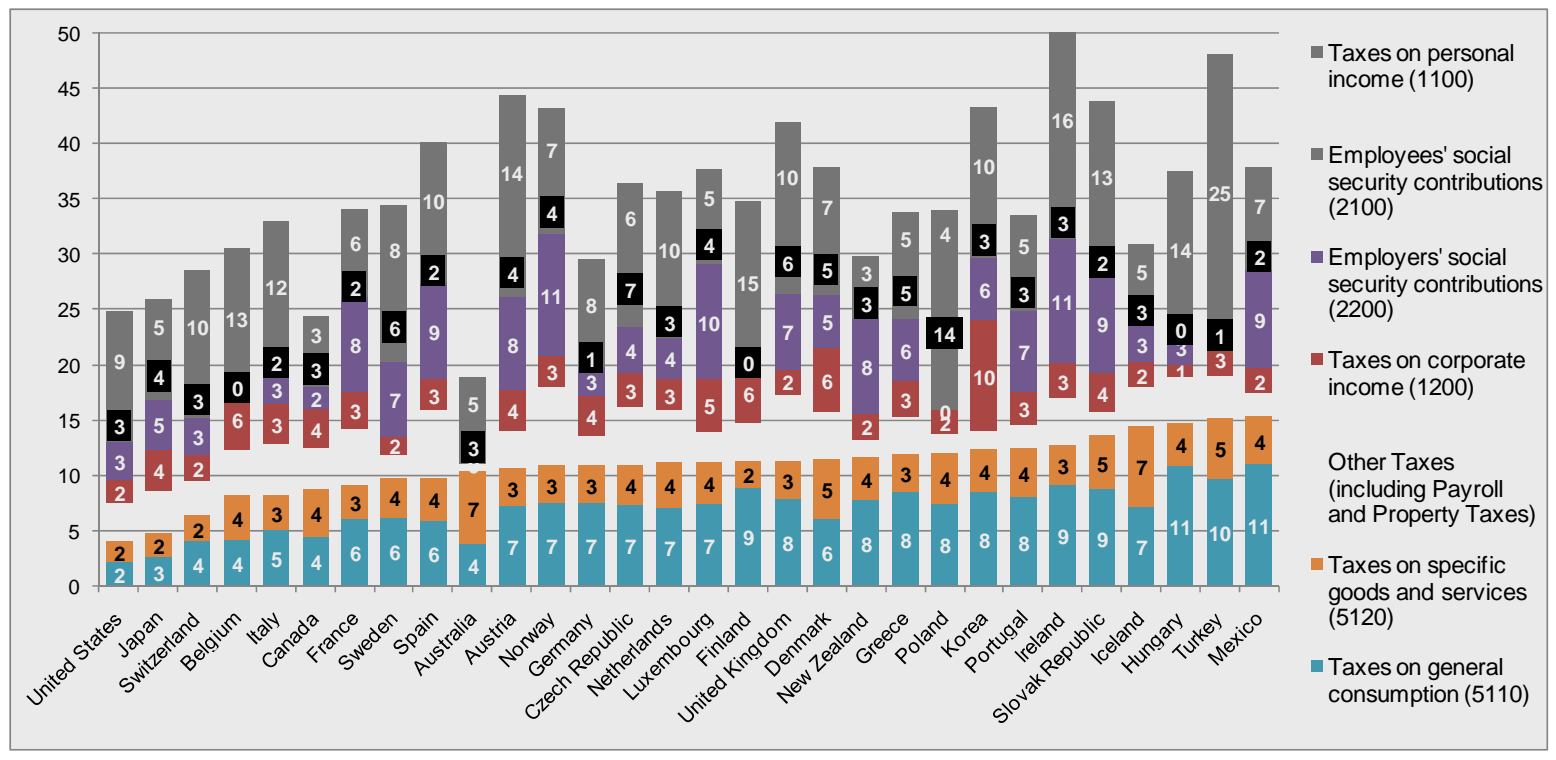

Note: Countries are ranked, from left to right, in increasing order of taxes on goods and services (5000) relative to GDP.

Source: OECD Revenue Statistics 1965-2005.

Figure 3. Composition of tax revenues across OECD countries

As a percentage share of total tax revenue in 2004

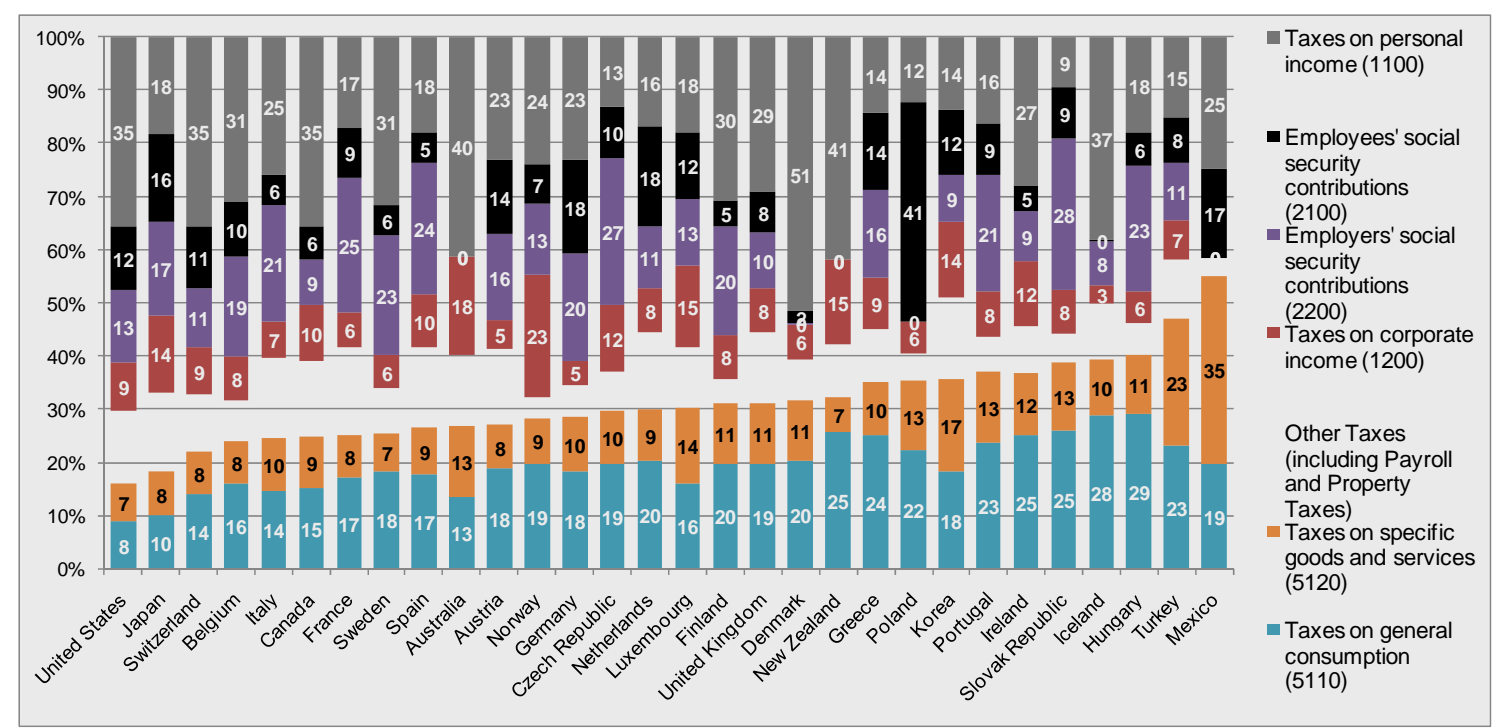

Note: Countries are ranked, from left to right, in increasing order of taxes on goods and services (5000) relative to GDP Source: OECD Revenue Statistics 1965-2005. 


\section{Modelling consumption tax incidence: theory and practice}

10. Taxes on consumption are typically collected by an intermediary, such as a retailer. However, an intermediary cannot ultimately bear the burden of a consumption tax as this must rest with individuals either as consumers, recipients of income or owners of assets. The question is how, in the presence of an intermediary, a consumption tax comes to be passed through to its ultimate bearer. The difficulties posed by this question go a long way to explaining why most studies on the distribution of household income focus on personal income taxes and government cash transfers (which are in effect negative income taxes). In the case of personal income taxes, the convention is to assume that the economic (or final) incidence is on the recipient of the income flow: this enables the economic incidence of personal income taxes to be estimated using survey data on individuals' income.

11. In the case of a consumption tax, even when household surveys collect data on household consumption expenditures, the tax burden is not obvious because the link between the statutory and economic incidence of the tax is complex. However, overlooking the distributive implications of consumption taxes simply because of the modelling complexity that this involves is fraught with dangers.

12. In reality there has always been a demand for empirical estimates of the distributional impact of consumption taxes. The challenge is to ensure that estimates are suitably qualified, fully explained and tested for sensitivity using the best available theoretical knowledge and data sources. It is for this reason that this section sets the scene by addressing the two critical issues confronting all empirical studies on the incidence of consumption taxes.

- The first relates to the conceptual issues which must be directly addressed when undertaking empirical estimates of the consumption tax burden on individuals within a household. This includes addressing the following questions:

1. What is the scope of the study? Does it cover all taxes or only selected ones?

2. How are taxes allocated to individuals? If all consumption taxes are ultimately shifted to individuals how does this happen and how does the process affect the final outcome?

3. How is the tax burden valued? Does it include only the tax paid or also other costs (such as those for compliance and administration)?

4. What approach is used to assess the incidence of the tax? Is the goal to estimate the absolute burden of a tax or of a revenue-neutral change in the tax structure?

5. What is the period of study? Is the focus on the year or on some other accounting period?

- The second critical issue is to evaluate how the total burden of consumption taxes is distributed between individuals. Answering this question requires decisions on:

1. The base for inter-unit comparisons (dollars or some welfare unit; annual or lifetime).

2. The unit of analysis (person, family or the household).

3. The equity measures used.

The answers given to each of these questions will reflect the objective of the study and the data sources available. In turn, the decisions taken can fundamentally influence the meaning and interpretation of the results obtained. 


\subsection{Incidence of taxes in theory}

13. Who bears the tax burden? Answers to this simple question are the subject of considerable debate. What is commonly accepted is the interest in the answer. Not only are communities concerned with equity, efficiency and simplicity of the tax system, so too are policy makers because of the impact of taxes on the economy, politicians and the voting public. The problem is that taxes are imposed in a multitude of ways across a range of different bases. Any study of the distributional impact of taxation must begin with an attempt to determine the ultimate burden of taxation on individuals. This section considers the conceptual issues raised in addressing this question.

What is the burden of a tax?

14. Details of tax revenue collected by government can be readily obtained from annual budget documents and official statistics. This is however only part of the burden of tax. By distorting behaviour, a "deadweight loss" (DWL) or efficiency loss is created. Also, the act of paying tax creates a compliance cost, and the agency empowered to administer the tax legislation must be funded by government to make the necessary tax collections. Moreover, a tax is not always what it might appear at first sight. Governments not only collect taxes, but they also can forgive taxes which would otherwise be due primarily in the form of tax expenditures (tax revenue lost as a result of deviations from some taxation benchmark - typically a comprehensively based tax). For example, the zero-rating of food under a VAT (as in Australia and the United Kingdom) has a similar objective to a VAT credit targeted at low income households (as in Canada) and to compensating low income groups through higher cash transfers following the adoption of a broad based VAT (as in New Zealand). The equivalence of these goals and the different mechanisms adopted to achieve them poses a challenge to any study on the incidence of consumption taxes. Focusing only on the tax revenue collected might not be enough - the mechanism for compensating various income groups for any adverse impacts might also need to be included.

15. The complexities involved in analysing the incidence of consumption taxes do not stop there. While some consumption taxes fund general government expenditure, others are earmarked to specific uses while yet others are user-pays levies more akin to the price of a publicly provided private good. The concept of a consumption tax and its burden is therefore neither simple nor transparent in practice.

\section{Economic versus statutory incidence of the tax burden}

16. The statutory (or legal) incidence of a tax tells us nothing about its economic (or final) incidence. As shown in Figure 4, taxes impact on economic activity at many different stages in the production and distribution process. Which institution collects the tax as a result of legislative arrangements might be interesting for some purposes but not when the goal is to assess the economic incidence of these taxes - or how they come to be ultimately incident on individuals. For example, knowing that firms are liable for taxes on their sales is important for tax administrators but tells us nothing on how these taxes ultimately impact on individuals. Similarly, workers and capital owners might provide their labour and capital to firms and in the process have the holding, transfer, and return from them taxed, but how do these taxes impact on individuals?

17. The shifting of the tax burden can be both the intended (and expected) consequence of the tax legislation and the unintended consequence of imposing the tax. In fact, one economic agent might shift the burden of a tax onto another agent by altering its market behaviour. For example, a tax on a firm's output (and the cost of complying with the relevant tax laws) may find its way through to higher consumer prices, to reduced wages paid to the firm's employees, to reduced returns to the owners of the business, to lower supply of the taxed good - or some combination of all these impacts. The reporting obligations of 
these taxes can also impact on taxpayers. The challenge for any consumption tax incidence study is how in practice to measure the tax burden on individuals.

\section{The counterfactual benchmark}

18. Examining the impact of tax on the individual requires the identification of some benchmark against which the taxes currently imposed are compared - the so-called counterfactual. At its most extreme, the counterfactual may be a situation without taxes. This would involve measuring the absolute incidence of the tax (Musgrave, 1974). However, a critical problem with this approach is how to model a zero-government environment, given that such an environment cannot realistically be perceived.

19. A different approach adopts a benchmark which can better accommodate issues which arise when estimating tax incidence in practice. One way of doing so is to examine the differential incidence of the tax. This would involve comparing the current tax system with some revenue (or budget) neutral alternative. Using this approach, the impact of government tax policies on aggregate demand and on the behaviour of firms ${ }^{8}$ (as investors and traders) and individuals ${ }^{9}$ (as consumers and factor owners) is minimised. In practice most applications of this approach only consider the first order effects of any change in tax policies. ${ }^{10}$

Figure 4. Circular flows and taxes

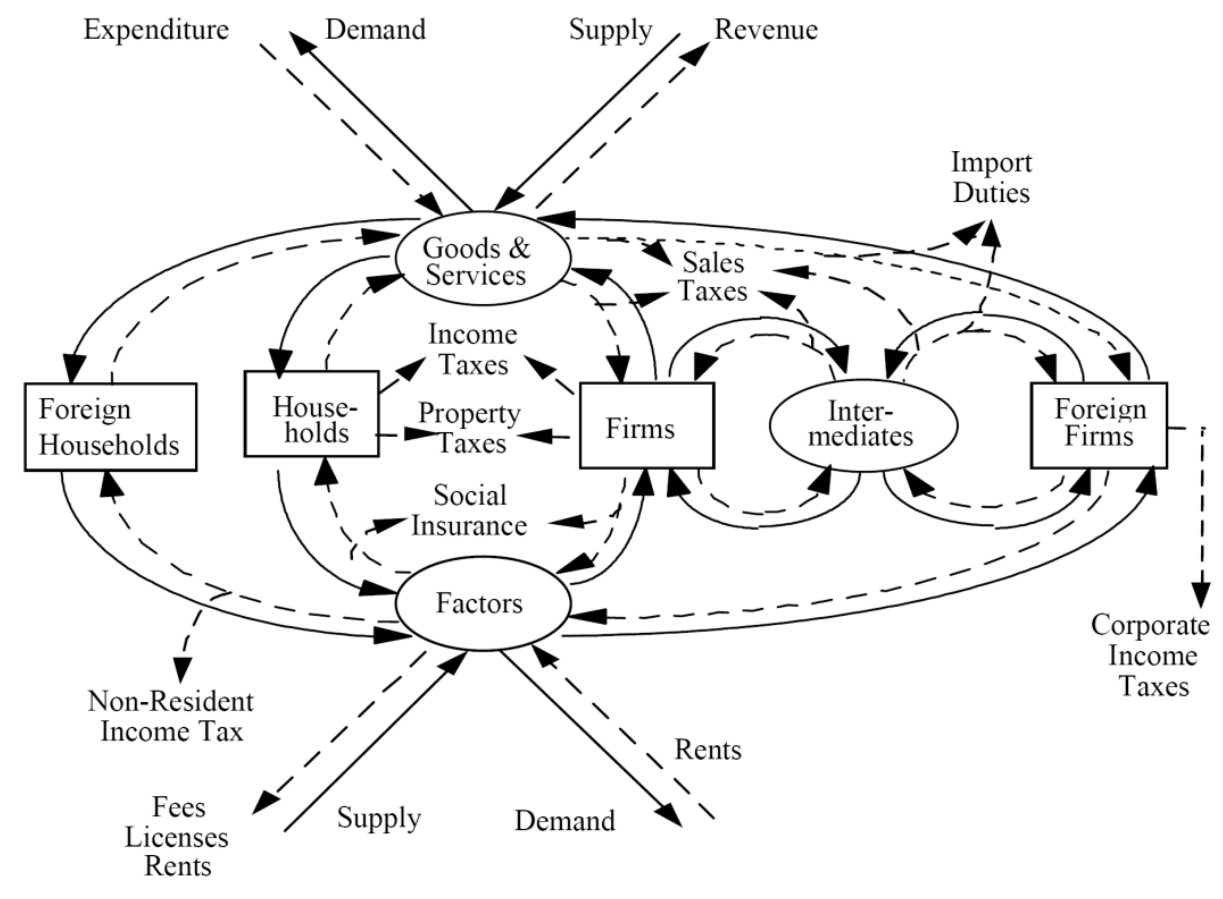

Source: The Oregon Tax Incidence Model (OTIM), Figure 2.4, <http://www.agribusinessmgmt.wsu.edu/Holland_model/docs/OregonTaxIncidenceModel.pdf $>$

8. Assuming unchanged investment, fixed factor inputs and use of produced inputs, and constant relative trade flows between regions and countries.

9. Assuming constant consumption bundle, labor supply and migration.

10. For example, see MIPS and SPIT (IFS) where only the behavioural adjustments by taxpayers who actually pay the tax are modelled. In models such as ORANI (Dixon and Meagher, 1990), these second order feedback effects are also included which factor in the impacts of the tax on all other markets. 


\section{Tax shifting}

20. The shifting of a tax requires information on the context in which it occurs - and only with this knowledge can we conjecture at the final incidence of the tax. For studies adopting a differential incidence approach, static analysis might be appropriate. This partial equilibrium analysis typically focuses on incidence under the assumption of limited or no behavioural response to the tax. It therefore ignores first and second order effects of the tax which would impact on other agents and the broader economy.

21. The alternative approach studies the incidence of taxes in a general equilibrium framework where first and second order effects are modelled. The difficulty of this approach is that tax shifting depends on many factors which are, in practice, difficult to specify. CGE models designed to examine the final incidence of taxes generally impose data/information demands which are not readily met. As a consequence, these models are often deterministic - driven by the parameter specification which itself can be controversial (Dixon and Meagher, 1990; Ballard, Fullerton, Shoven and Whalley, 1985).

22. Complicating the issue further is that the shifting of each tax cannot be examined in isolation from other taxes. For example, examining the shifting of one tax while holding other taxes constant produces results that cannot be aggregated to give an indication of the effect of shifting all taxes. In practice, all tax shifting assumptions are controversial. As a result, simplistic assumptions are ultimately made about tax shifting: in the case of consumption taxes, the common assumption generally used is that they are shifted fully forward to the final consumer of the good or service.

\section{How is the tax burden valued?}

23. While the traditional tax shifting assumptions only allocate the value of (or change in) the tax revenue collected from individuals, this overlooks whether taxes should be valued at their nominal cost to taxpayers or whether these nominal costs differ across individuals and groups.

24. In theory, taxes should not be valued across different taxpayers on the basis of the revenue raised. In practice, this is the procedure adopted. Criticism of this approach can be mounted at two levels: how taxes should be costed more generally in the economy, and how they should be valued when they impact on different individuals. If the objective of tax incidence studies is to compare the current distribution of resources to some pre-government distribution, then it must be recognised that the tax revenue raised does not reflect the full burden on the economy and individuals from the imposition of taxes.

25. While the revenue collected from taxes is visible, policy makers are also concerned about less visible impacts. These are the efficiency, administrative and compliance costs of taxation. The latter two burdens are rarely comprehensively measured and almost never considered in studies of the distributional impact of consumption taxation. Box 1 illustrates the concept of DWL using a partial equilibrium approach for the case of an excise duty imposed on a single commodity. Critical to the magnitude of the deadweight loss are the elasticity of the demand and supply curves: the greater the substitution effect as a result of the relative price change arising from the tax, the greater the DWL - whether it is the producer or the consumer altering their behaviour as a result of the imposition of the tax. 


\section{Box 2. A simple graphical illustration of the effect of an excise duty on demand and supply of a given commodity}

While most studies into the distributional impact of consumption taxes assume the burden of consumption taxes falls totally on consumers, this is only the case if supply is perfectly elastic and/or demand is perfectly inelastic. Panel (a) presents a partial equilibrium view of this case with consumers paying all the tax collected which is equal to $\mathrm{P}_{1} \mathrm{P}_{2} \mathrm{AB}$.

But the assumption that supply is perfectly elastic and/or demand is perfectly inelastic is not the normal case. Panel (b) illustrates the case where demand is downward sloping and supply upward sloping. In this case the revenue collected is $\mathrm{P}_{3} \mathrm{P}_{2} A C$, with $\mathrm{P}_{1} \mathrm{P}_{2} A B$ is from consumers and $\mathrm{P}_{1} \mathrm{P}_{3} C B$ from producers. However, this is not the end of the story in relation to the burden arising from the imposition of the excise duty. There is also the loss of social welfare arising from the impact of the tax on consumer and producer behaviour. It is here that we must consider the 'deadweight loss' (DWL) associated with the imposition of this tax. When demand is perfectly inelastic, there is no distortion to welfare because the tax does not impact behaviour - and as a result, no 'deadweight loss' (DWL) is associated with the imposition of the excise (Panel a). When demand is downward sloping and supply perfectly elastic, the DWL is equal to the loss of consumer surplus equivalent to ABD. However, careless studies estimate the DWL in Panel (a) as ABE, which is incorrect.

This is because they fail to make a distinction between the traditional Marshallian (uncompensated) demand curve and the Hicksian (Compensated) Demand Curves. The key difference between these two curves is that along an uncompensated demand curve, welfare varies with relative prices changes while along a compensated demand curve, welfare is constant. Since in estimating DWL, our interest is only in the welfare loss arising from the distortion to consumer preferences (due to relative price changes), it is compensated demand curves which should interest us. This is because this curve removes the welfare effect of the effective change in income due to relative price changes (income effect IE) and reports only the substitution effect (SE). In Panel (a), when demand is downward sloping, removing the tax increases consumer surplus by $A B D$ with no change in producer surplus. In Panel (b), removing the tax increases consumer surplus by ABD and producer surplus by CBE. If an individual's demand does not depend on their income, then the compensated and uncompensated demand curves coincide (IE=0). If demand is influenced only by income, then the two curves differ by the income effect.

Panel (a)

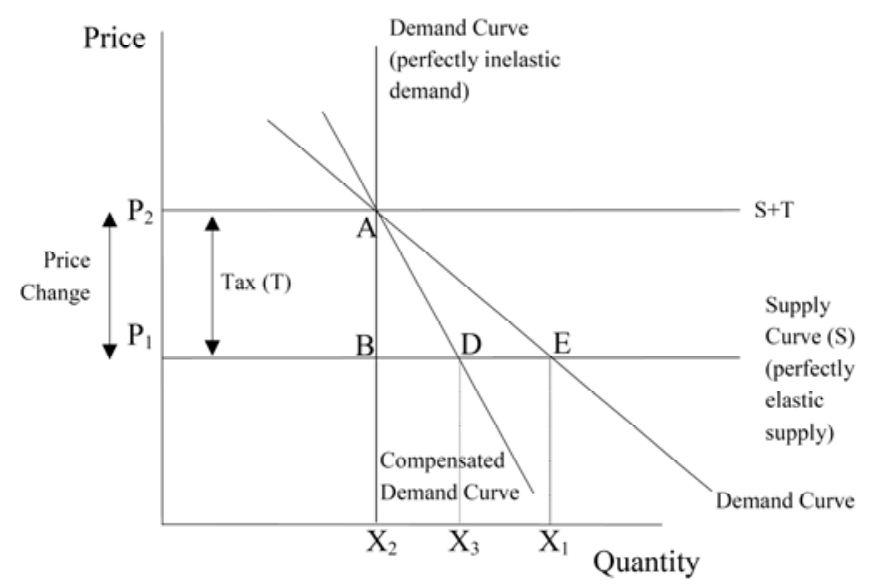

Panel (b)

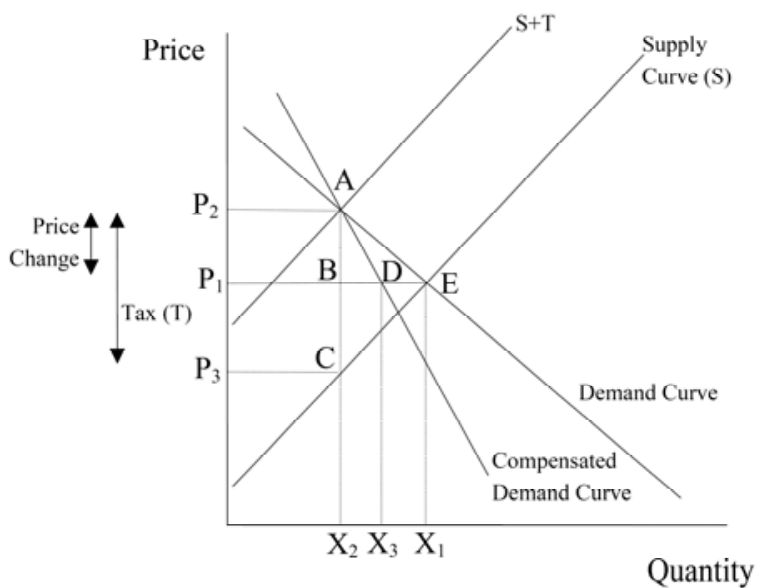

While the approach shown in Panels (a) and (b) demonstrate the case where a tax is removed, thus pivoting the demand curves at $A$, it would be just as appropriate to examine the case of a tax being imposed where none previously existed, hence pivoting the demand curves at $\mathrm{E}$.

What is apparent is that there is no economic reason why the DWL associated with the imposition of consumption taxes can be ignored in distributional impact studies nor that the revenue collected from such taxes should be assumed fully borne by consumers. Despite this observation, in practice DWL is typically assumed to be zero and the tax is assumed to be fully shifted forward to final consumers. This assumption might be reasonable when the focus is only on the impact of small tax changes which are revenue neutral. In this case, IE can be assumed constant so that the change in IE is zero, making reasonable the assumption that the compensated and uncompensated demand curves coincide. 
26. Traditionally, distributional impact studies do not include either DWL or the compliance and administrative costs of taxation. This is not an unreasonable assumption in studies based on the differential tax incidence approach, since the consideration of revenue-neutral alternatives to the current tax system implies minimizing (or effectively removing) any first order (behavioural responses) and second order (broader macroeconomic) effects. When this approach is combined with the adoption of tax shifting assumptions which reflect the differential effects of the tax changes on individuals, they effectively address the GE problem. In practice, this approach reflects the adoption of simple (and strong) assumptions such as that all consumption taxes are fully passed through to household final consumers.

27. The second area of contention is whether the nominal tax burden imposed through taxation should be attributed equal weight (in terms of benefits forgone) for different household groups. This raises issues about interpersonal comparison that are discussed later.

\section{2. $\quad$ Modelling incidence of tax in empirical studies}

What is the period of study?

28. While information on tax collected has an annual focus, this period has no intrinsic economic significance, other than as an accounting concept. In the case of tax incidence studies, more relevant is how the tax impacts over an individual's lifetime or how that burden varies during their lifecycle. ${ }^{11}$

29. Data availability is a key constraint here. While cross-section data provide a snapshot of tax incidence, they can also be applied to the study of lifecycle tax incidence (by for example, examining age ranges for household heads). Cross-sectional data have also been used to create hypothetical lifetime data. With the increasing prevalence of panel data, lifetime tax incidence is becoming the focus of increased attention.

30. Nonetheless, when the focus is on the immediate plight of citizens, the focus of research into the distributional impact of consumption taxes will be on the 'here and now'. It is therefore not surprising that most studies focus on a point-in-time snapshot of tax incidence with some examination of how it varies across different ages of the household head.

\section{Data issues}

31. Four primary data sources are required in tax incidence studies: taxation statistics; aggregate income and expenditure statistics; income and expenditure data for individual households; and information on tax shifting.

32. Data on taxation can be obtained in the form of either aggregate official national data or in disaggregated form. Aggregate tax data is readily collected by all governments and reported in annual budget statements, official statistical publications, and in international compendiums based on some common classification system such as the OECD (2006). This data can be complemented with those reported by the tax revenue collection agencies (e.g. Australia's ATO). However, these statistical sources only report data on what is collected and do not provide guidance as to how such taxes ultimately come to be borne by individuals in households.

11. See further discussion of this issue in 3.3.3. 
33. To this end, two additional statistical sources must be accessed. The first is surveys of household income and expenditure. Most surveys collecting data on individual income also collect information on the personal income tax and employee social security contributions paid. However, only a few surveys also collect data on consumption expenditure, and those that do generally do not provide information on the taxes hidden in this expenditure.

34. What is required is insight into how taxes on the inputs and outputs of producers and distributors come to be passed forward to individuals as consumers. It is here that the National Accounts Input-Output data play a critical role. Input-output tables allow identification of how the statutory incidence of consumption taxes ultimately flows through to household final consumers. Figure 5 illustrates how empirical studies of tax incidence might differ in terms of their use of Input-Output data. This issue will be shown in Section 4 to be a key feature distinguishing the different empirical estimates of tax incidence and critical to the comparability of their results.

Figure 5. Alternative ways of allocating consumption taxes to household final consumers

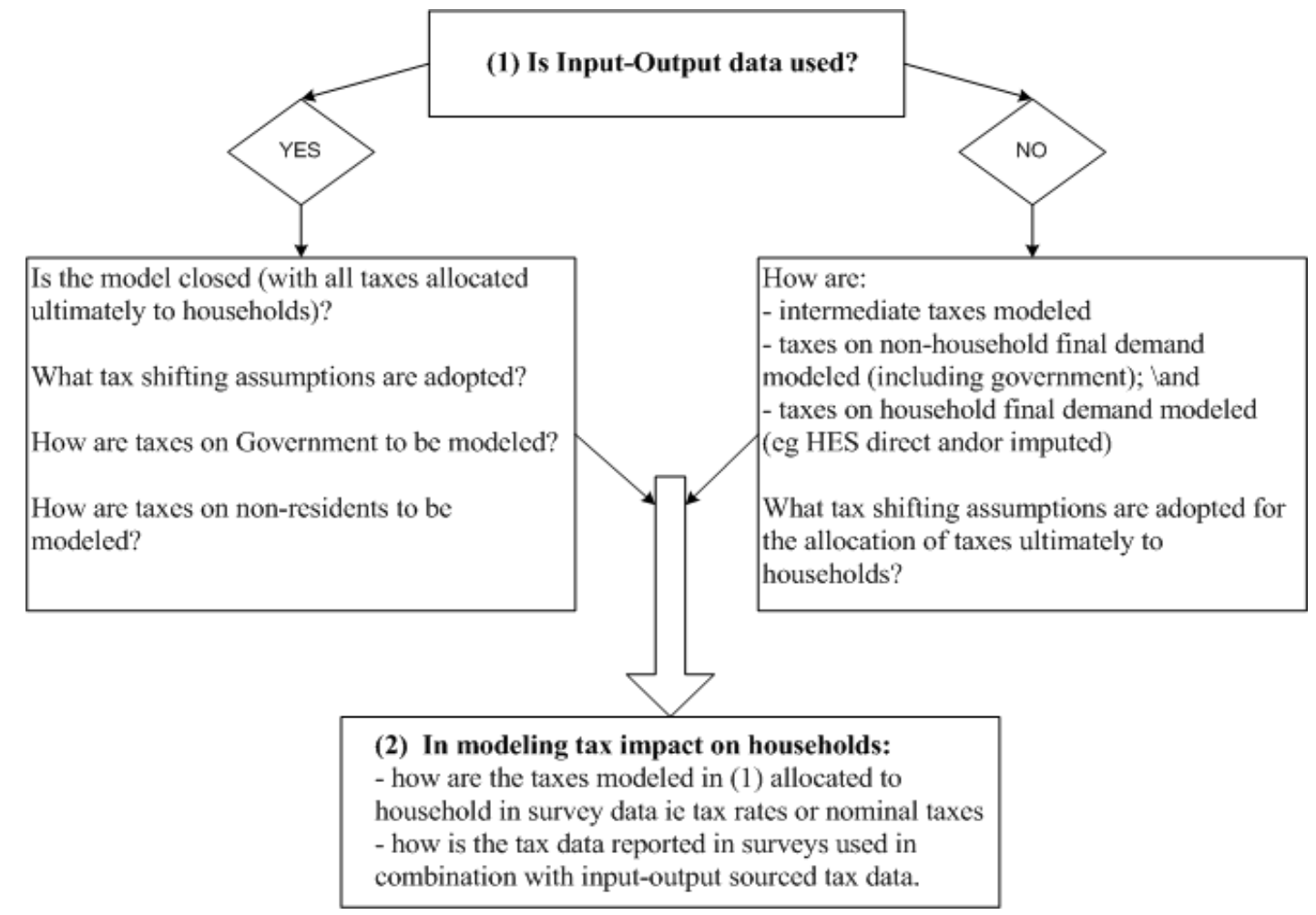

Source: Author's elaboration.

\section{Coverage of taxes}

35. Although this study is only concerned with consumption taxes, what constitutes a consumption tax is not beyond dispute. After all, if interest is in those taxes which are ultimately incident upon consumption, then this may be more than just those taxes which are traditionally seen as levied on consumption. A more comprehensive approach would also include taxes on capital and labour inputs into the production and distribution process, or those taxes on capital related transfers that are ultimately shifted to consumers. 
36. A more basic question is whether a study of the distributive impact of consumption taxes also includes subsidies (negative consumption taxes), consumption tax-expenditures, non-tax revenue such as user-pays fees and charges and dedicated (ear-marked) taxes - or the shifting of other taxes onto consumption. Exclusion of such taxes will result in a partial view of the impact of government taxes on consumption.

\section{Tax shifting assumptions}

37. Whether the focus is on differential or absolute incidence, consumption taxes are invariably assumed to be fully passed through to household final consumers of any consumption tax collected. An often overlooked complication arises from the distinction between national and sub-national consumption taxes. This is relevant, for example, in the case of taxes specifically targeted to non-residents (such as gambling taxes, tourist charges and taxes imposed on purchases by non-residents or the ownership of assets held in one region by non-residents). It could be argued that comprehensive distributional impact studies should not only consider the shifting of taxes intra-nationally but also between residents in national jurisdictions.

38. In practice, studies into the distributional impact of taxes do not consider inter-jurisdictional tax shifting (an exception being Warren, 1989a). Even studies examining sub-national taxes typically ignore tax shifting between residents in different sub-national jurisdictions. The main reason for this is the complexity of modelling inter-jurisdictional tax shifting and the assumption that, in most cases, the net effects of this two-way flow of taxes will balance out.

39. Also omitted by most studies is tax shifting between sub-national and national jurisdictions which can arise when a tax in one jurisdiction is deductible against the tax liability in another, either through a credit mechanism or because it is a deductible expense. Again, complexity is the key constraint on modelling such considerations. Addressing this effect would not only require detailed identification of different taxes in different sub-national jurisdictions and information on the shifting between the national and sub-national governments, but also attributing them to specific taxpayers. Instead, it is typically assumed that taxes in sub-national jurisdictions are borne by the residents of that jurisdiction, and that national taxes are borne by residents and non-residents of the country - while ignoring taxes imposed on residents by other countries. With a closer economic integration, such assumptions may become less reasonable; as for example in distributional impact study within the EU.

\section{Modelling framework}

40. Figure 6 outlines an input-output framework of how consumption taxes come to be ultimately borne by individuals assuming their full forward shifting to individual consumers (Warren, 1998). This framework provides a way of thinking about how taxes whose statutory incidence is on firms are ultimately passed through to individuals as the final consumer and will form the basis for comparing the different methodologies applied in empirical studies examined in Section 4.

41. Consumption taxes can be divided into two categories: those on inputs into the production and distribution of goods and services (labelled as INTAX in Figure 6) and those on expenditure by final consumers (FDTAX, i.e. FD1 to FD7) of which households are one such consumer. Those consumption taxes which are directly on households when they purchase from a retailer are shown by A. However, this is only part of the total consumption tax collected by Government. Also embedded in retail sales to households is the tax on intermediate inputs into the production of those goods shown by B in Figure 6 . However, these intermediate taxes impact not only on households (B) but also on the final consumption of non-household final consumers (FD2-FD7). 
42. While the pass through of $\mathrm{A}+\mathrm{B}$ to household final consumers is relatively straightforward, the important question is how intermediate and final consumption taxes on FD2-FD7 become incident on resident households. Different approaches have been adopted to address this issue and these are shown schematically in Figure 6. A common approach is to assume that taxes on investment goods by private and public enterprises (or FD2 and FD3) are also inputs into the production of goods for FD1 and FD4-FD7 and should therefore be modelled as passed through (shown by $\mathrm{C} 1$ ) to the other categories of final consumers. ${ }^{12}$ Even when adopting this approach, the question remains as to how those taxes impacting on FD4 to FD7 impact on resident households.

43. With respect to consumption taxes paid by general government (FD5 and FD6), two approaches are commonly adopted. The first simply ignores this tax and consequently reduces the nominal amount of government expenditure by this tax (D1). The alternative is to allocate this tax burden to individuals (D2) while leaving government expenditure unchanged in nominal terms.

44. Changes in stocks of goods (FD4) are generally either ignored (D1) or allocated to current consumers (D2). For taxes incident on exports (FD7) two basic approaches find adoption: that they ultimately impact on non-resident consumers when they consume these goods in their countries of residence (E1); or that countries cannot "export" its tax burden if this makes price uncompetitive in international markets. In this second case, the assumption is that a country's exchange rate will adjust to restore its competitiveness and this impact is distributed across households, as in the case of taxes on resident households (shown by E2).

45. As Figure 6 illustrates, even assuming the full forward shifting of consumption taxes to households does not yield a simple approach to estimating the incidence of consumption taxes on individuals in domestic households. This holds even ignoring the possibility that some of these consumption taxes might become incident on the owners of factor inputs (labour and capital) into the production of these goods or on the suppliers of produced inputs into their production.

12. It will be shown in Section 4 that this is the approach adopted officially by the UK ONS (2007), Australian ABS (2006) and Statistics Canada (SDSP/M 2007) and in Scutella (1999). 
Figure 6. Modelling of consumption taxes under the assumption of full forward-shifting

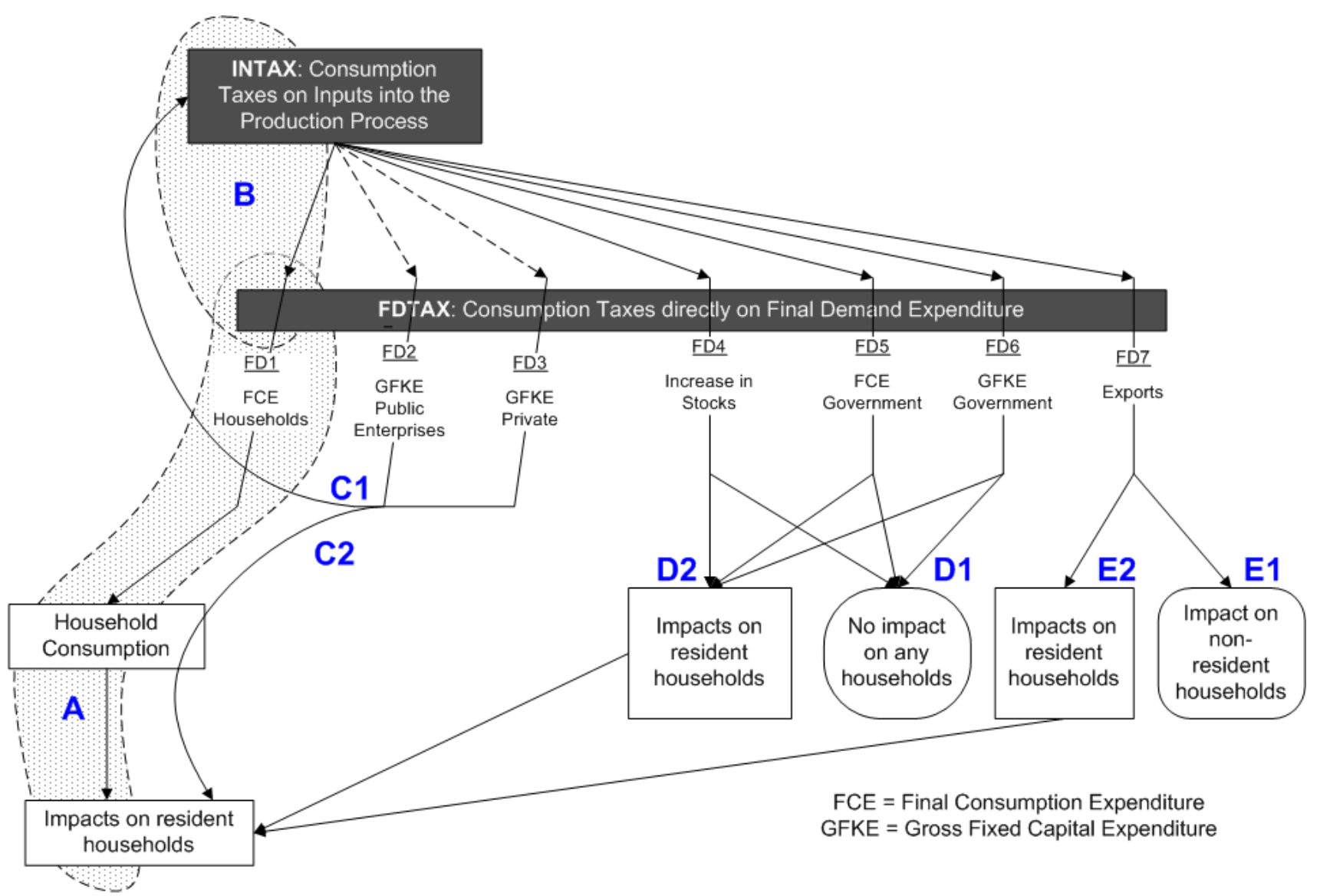

Source: Author's elaboration.

\subsection{Evaluating the distribution of consumption taxes}

46. Knowing statutory tax rates on or the total tax collected from some particular commodity is only the first step in assessing the distributional impact of these taxes across different individuals and households. Examining the distribution of consumption taxes between individuals requires access to detailed data on income and consumption expenditure by different household groups.

\section{Population coverage}

47. As important as the coverage of consumption taxes is the coverage of the population on whom these consumption taxes are incident. At its broadest, this would include both residents and non-residents, the latter incurring a burden as a result of exports of domestically produced goods and services. In practice, consumption tax incidence studies only focused on the domestic population and domestic taxes.

48. One complication with using household survey data is that its coverage is narrower than the overall population. This is because household surveys typically exclude those in non-private dwellings or in remote areas (ABS, 2006, p. 34) - resulting, in Australia, in only 98\% population coverage. Difference in coverage is common but depends on the approach taken to modelling tax incidence. 


\section{Unit of analysis}

49. The unit of analysis in tax incidence studies depends on the objective of the study and the survey data available. In theory, household surveys collected data at three levels: persons, families, and households. While income data is collected in surveys according to who is the recipient (e.g. individual for wages and salaries and the family for income flowing from jointly held assets), expenditure data is only available at the household level where the household is defined as a group of individuals who live together and have common housekeeping arrangements. Also, since no two households are alike in terms of their socio-economic and demographic characteristics, focusing on the distributional impact of consumption taxes across households might not be that informative. The solution is to focus on that unit which is common to both families and households - the individual.

\section{Base for inter-unit comparisons}

50. While knowing the allocation of consumption taxes to specific households is important, it does not inform us of how individuals in one household are impacted relative to those in another. To know this requires estimating the well-being (or welfare) of each household. This involves a two staged process: firstly, determining the financial means available for satisfying a household's needs; and secondly, recognizing there are economies of scale within different households.

51. With reference to the first element, most studies rely on an income concept derived from a crosssectional household survey. In practice, as shown in Figure 7, the annual income measure adopted varies depending on the particular tax considered and the purpose of the study. Those concerned with the distributive impacts of consumption taxes invariably include these taxes in an income measure that goes beyond the conventional definition of household disposable income.

52. To measure household's economies of scale in consumption, most studies adjust income for economies of scale in consumption though "equivalence scales" such that:

$$
W=\frac{D}{s^{E}}(1)
$$

where $\mathrm{W}$ is economic well-being, $\mathrm{D}$ is gross (or disposable) income, $\mathrm{S}$ is household size (number) and $\mathrm{E}$ is the equivalence elasticity (Atkinson, Rainwater and Smeeding, 1995). 
Figure 7. Different income concepts and stages of redistribution

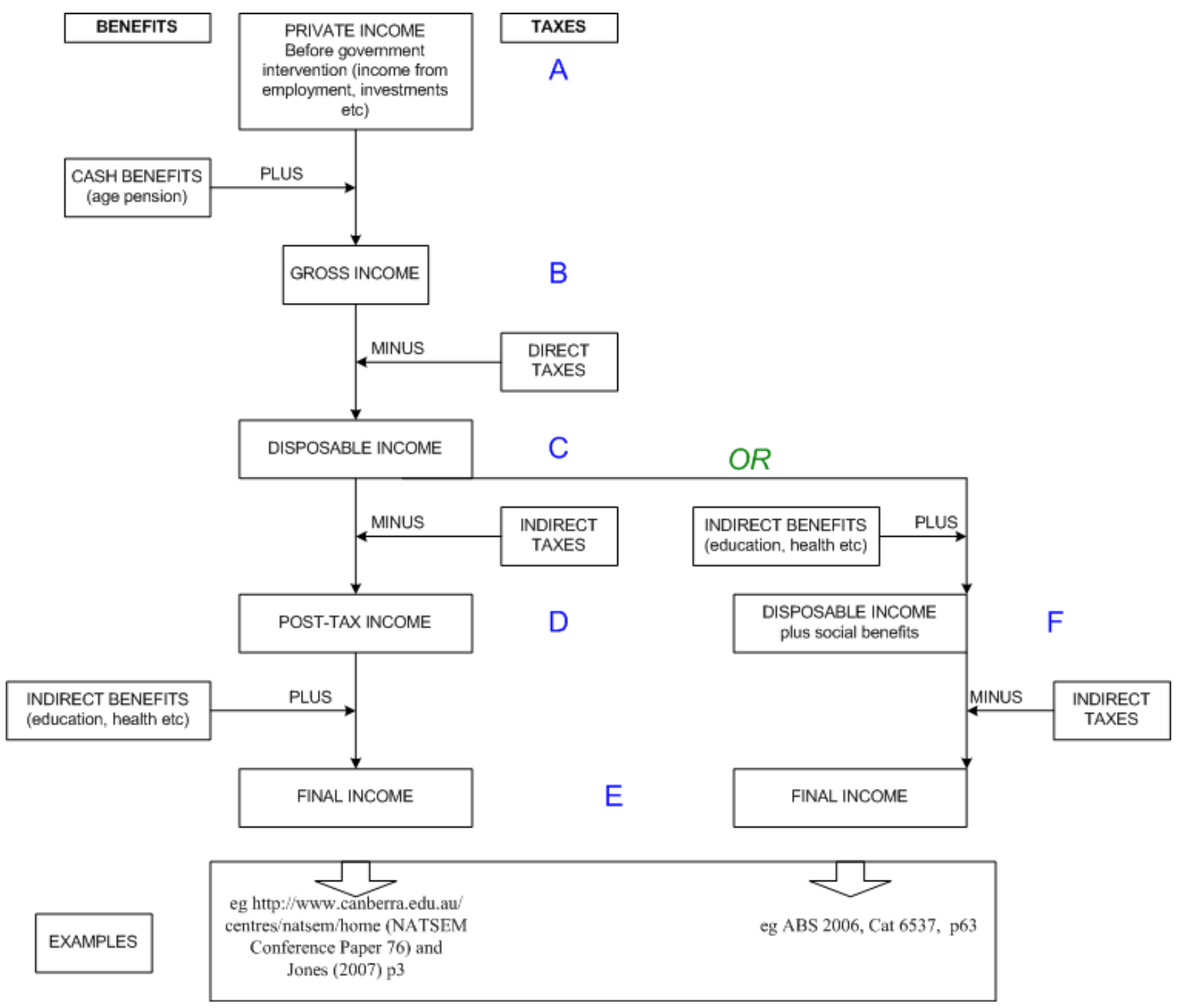

Source: Author's elaboration.

53. All studies on the economic well-being of individuals and households agree that some equivalence scale should be adopted but as to what value, there is no clear answer. A commonly used scale is the "modified OECD equivalence scale" - where the first adult in each household has a weight of 1.0 , the second and subsequent adults have a weight of 0.5 , and dependent children a weight of 0.3 ; this is closely approximated by $\mathrm{E}=0.6$ in (1) - as used in ABS (2007). Other commonly used scales are 1:0.7:0.5 (Warren, Harding and Lloyd, 2005; Whiteford, 1985), which is proxied by $E=0.75$; and $E=0.5$, which is the scale used in all OECD reports on the subject.

54. Using $\mathrm{S}^{\mathrm{E}}$, each individual can be ranked according to his or her equivalent income or economic well-being. However, ascertaining a household's well-being does overlook many factors other than income which may impact on a household's needs, such as conditions of work (including hours worked), life cycle differences in earning and spending patterns, the value of home production, the imputed benefits from owner occupation, the receipt of fringe benefits, the impact of unrealized capital gains and the benefit from retained earnings by corporations. 


\section{Annual and life-time incidence of consumption taxes}

55. While annual income is commonly adopted in studies of the incidence of income taxes, there is some debate about the appropriateness of this measure in studies of the incidence of consumption taxes. The distinction is important, as while consumption taxes appear to be regressive based on annual income, they are likely to be less regressive and even progressive when their effect is assessed over an individual's lifetime, (Creedy, 1999 2002; Poterba, 1989; Metcalf, 1997; Fullerton and Rogers, 1993).

56. Critical in this debate is the appropriateness of using annual income as a measure of an individual's potential well-being when consumption depends on an individual's lifetime income. People know that over their lifetime, their annual income will first be low, peak in middle age and then fall in old age, and that they will factor this in when determining annual consumption. The result is a relatively stable level of annual consumption over the lifecycle, despite fluctuations in annual income. This implies that cross-sectional studies of consumption tax incidence based on annual income will present more regressive results for the young and the old (lower-income groups often dissaving) than for the middle aged (higher incomes with positive savings). Clearly, dissaving by low income groups as measured by annual income and expenditure surveys is not sustainable; care must therefore be taken when interpreting the distributional impact of consumption taxes using such data sources.

57. This argument suggests that a more appropriate measure of well-being for consumption tax incidence studies is an individual's expected lifetime income. When all people are exactly the same earning the same income, making the same expenditure and paying the same amount of taxes over their life-course - the lifetime incidence of all taxes would be proportional, regardless of whether lifetime income or consumption are adopted as the measure of well-being.

58. The challenge is how to measure lifetime income in practice. One approach is to use annual consumption as a proxy for lifetime income on the basis that it is less volatile than annual income. Based on this approach, various studies have found that the regressivity of consumption taxes is significantly lower than when assessed based on annual income, and could even become progressive when considering consumption tax credits (Poterba, 1989, 1991; Metcalf, 1993, 1997; Feenberg, Mitrusi, and Poterba, 1996).

59. The attractiveness of annual consumption is that this data is readily available and the approach is simple to apply. The downside is that annual consumption may not be a good proxy for lifetime income because consumption is not stable over the lifetime (Caspersen and Metcalf, 1994). Consumption also follows a lifecycle pattern similar to but less accentuated than income.

60. One solution is to use lifetime rather than annual consumption. Fullerton and Rogers (1991, 1993) estimated tax incidence based on age-income profiles and lifetime income measure. They concluded that while both corporate and individual income taxes appeared to be less progressive in a life-cycle framework than under a snapshot analysis, sales and excise taxes were less regressive - with the result that the overall incidence of the U.S. tax system was similar to that measured based on annual income. ${ }^{13}$

61. In summary, two basic approaches are used in the literature on consumption tax incidence to address concerns about life-course redistribution (and ability to pay taxes, Poterba, 1993):

1. Measure annual tax burdens relative to lifetime income (as in Poterba 1989 ,1991; Metcalf, 1993, 1997); and

2. Measure lifetime tax burden relative to lifetime income (as in Fullerton and Rogers, 1996).

13. See also Fullerton and Rogers (1996), Lyon and Schwab (1991) and Metcalf (1997). 
62. Despite these approaches, most consumption tax incidence studies continue to focus on a snapshot approach focused on the annual tax burden relative to annual income derived from a crosssectional household survey. As shown in Figure 7, the income measures adopted in practice vary depending on the particular taxes considered and the purpose of the study. Those concerned with the distributional impacts of consumption taxes invariably include these taxes in an income definition that goes beyond the conventional definition of disposable income. In an attempt to reflect lifetime considerations, many studies also attempt to proxy lifetime income by presenting their annual income snapshot by distinguishing individuals based on their age. However, as will be apparent from the review in this paper, both approaches remain rare.

\section{Equity measures}

63. Having identified the unit of analysis (the individual) and the basis for ranking these units (W in 1), attention turns to evaluating how equitably taxes are distributed between them. This cannot be determined without some notion of what is an equitable distribution. To this end, two basic measures are used: single number measures and other descriptive measures. Single number measures can be divided into those based on the Lorenz curve and those based on the generalized entropy measures, of which Lorenz curve based measures are the most commonly used. ${ }^{14}$

64. When income is equally distributed, it can be shown as the diagonal line SRX in Figure 8. When income is not equally distributed, the Lorenz curve could be represented as SZX and income inequality be measured by reference to A. The Gini index of income inequality is $2 * \mathrm{~A}$, and varies between a value of zero (for perfect equality) and unity (in the case of perfect inequality).

65. The of Lorenz curve and Gini index can be applied to study the re-distributional impact to taxes where our interest is in the vertical (how 'equal individuals in equal circumstances should be treated equally') and horizontal (how 'different individuals in different circumstances should be treated differently') equity implications of tax design. If we define A in Figure 8 as the difference between posttax income (Y) and pre-tax income (X) then the effect of taxes on income distribution can be measured by:

$$
\mathrm{L}=\mathrm{C}_{\mathrm{A}}^{\mathrm{A}}-\mathrm{C}_{\mathrm{B}}^{\mathrm{B}}
$$

where $\mathrm{C}_{\alpha}^{\mathrm{A}}$ is the concentration (or Gini Index) of after-tax income $\mathrm{X}$ with ranking based on after-tax income $\mathrm{X}$ and $\mathrm{C}_{\mathrm{E}}^{\mathrm{S}}$ is that for before-tax income $\mathrm{Y}$ with ranking by before-tax income $\mathrm{Y}$. This is the socalled Reynolds and Smolensky (1977b) measure of the redistributive impact of the tax system, ${ }^{15}$ with negative values of $\mathrm{L}$ indicating that income inequality is reduced by the tax (which is defined as an 'income inequality improving' tax) and positive values implying that the tax worsens income inequality.

14. For an overview of the Lorenz curve based and other measures, see Creedy (1999), Leigh (2005) and Kesselman and Cheung (2004) Table 2, p724<http://www.ctf.ca/pdf/04ctjpdf/04ctj3-kessel.pdf>.

15. This approach is similar to that proposed by Musgrave and Thin (1948) who proposed an index expressed as the ratio of the post-tax Gini and pre-tax Gini or $\frac{1-c_{A}^{4}}{1-c_{3}}$ 
Figure 8. Lorenz curves and concentration indexes

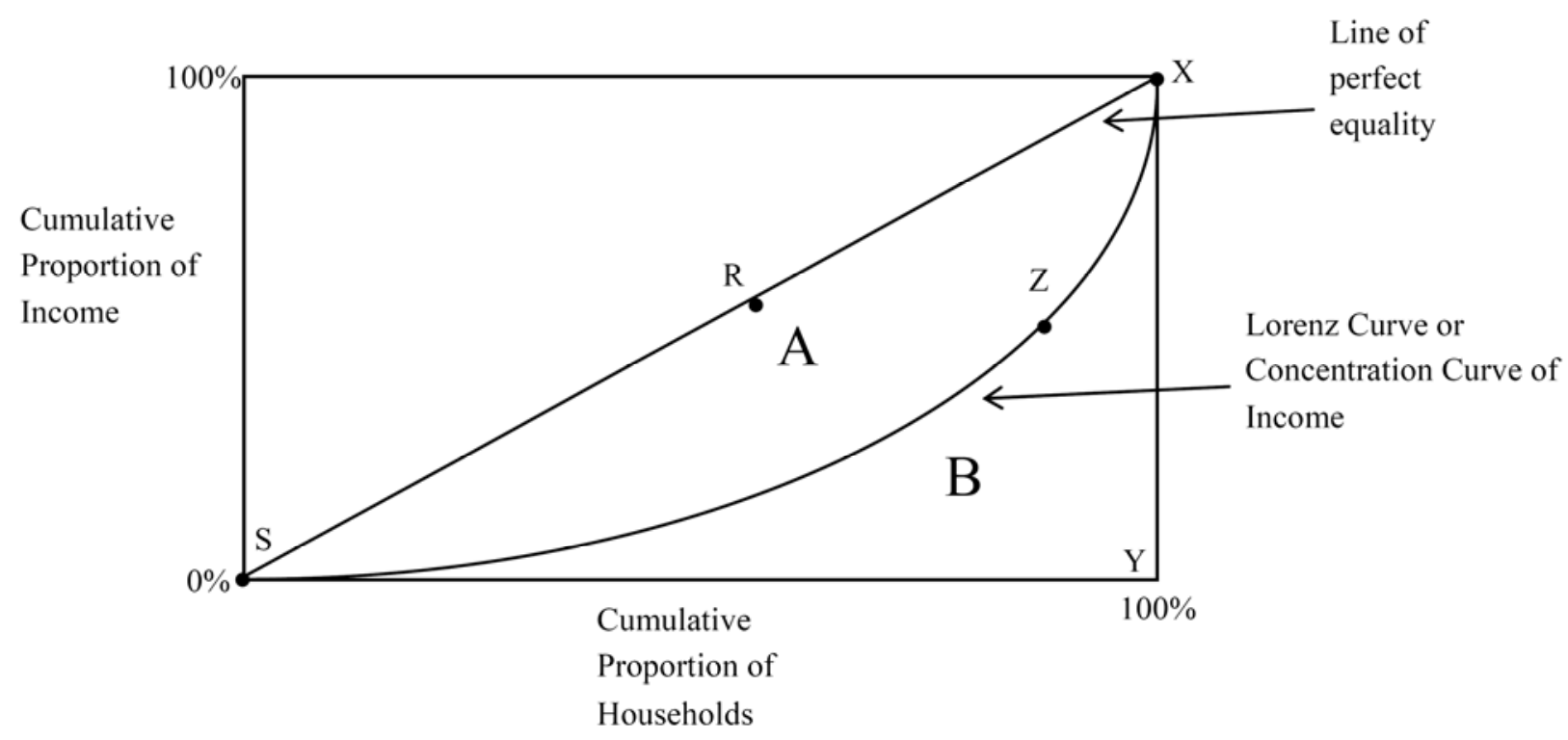

Source: Author's elaboration.

66. The redistributive impact of a tax can arise from three factors: the level of the tax, the progressivity of the tax and the re-ranking effect of the tax. To highlight the role of these three factors, Suits (1977) and Kakwani (1977b) developed conceptually related measures of tax progressivity. The Suits Index is the ratio of the area under the concentration curve for a tax to the area under a proportional line. Using Figure 8 , the Suits Index is the ratio $(\mathrm{B} /(\mathrm{A}+\mathrm{B})$ so that with a progressive tax the Suits index is positive (and $\leq 1$ ) and with a regressive tax it is negative (and $\geq-1$ ). If the concentration curve maps the cumulative distribution of tax on the vertical axis and before tax income on the horizontal, then the Suits Index can be represented as:

$$
S=1-\frac{c E}{x}
$$

where $\mathrm{K}$ is the area under the line representing the proportional distribution of tax.

67. Kakwani (1977b) built on the approached developed by Suits $(1977)^{16}$ to decompose L into its two constituent parts. His measure compared the distribution of the tax to the distribution of pre-tax income and defined tax progressivity as:

$$
\mathrm{K}=\mathrm{C}_{\mathrm{t}}^{\mathrm{B}}-\mathrm{C}_{\mathrm{E}}^{\mathrm{E}}
$$

where $\mathrm{C}_{\mathrm{t}}^{\mathrm{B}}$ is the concentration index of tax $\mathrm{t}$ with ranking by pre-tax income $\mathrm{B}$ and $\mathrm{C}_{\mathrm{B}}^{\mathrm{B}}$ is the concentration index of pre-tax income $\mathrm{Y}$ with ranking by pre-tax income. If $\mathrm{K}$ is positive, then the tax is progressive since a tax which is more unequally distributed than B will improve income inequality. A value of $\mathrm{K}$ less than zero has the opposite effect, worsening the distribution of pre-tax income.

16. The Suits index is calculated as the ratio of the area under the concentration curve for a tax to the area under a proportional line. Using Figure 8, the Suits Index is the ratio $(B /(A+B)$ so that with a progressive tax the Suits index is positive (and $\leq 1)$ and with a regressive tax, negative (and $\geq-1$ ). 
68. The complication with $\mathrm{K}$ is that it assumes no re-ranking as a result of the tax being imposed. This can be plausible when tax burden depends on factors such as household demographic and social attributes but not when it is based on income. This re-ranking is also a measure of horizontal inequities associated with the tax as it reflects similar groups incurring differing tax burdens. In fact, (2) can be decomposed into $\mathrm{K}$ and a re-ranking effect $\mathrm{R}$ as:

$$
\mathrm{L}=\mathrm{C}_{\mathrm{A}}^{\mathrm{A}}-\mathrm{C}_{\mathrm{D}}^{\mathrm{B}}=\mathrm{K}\left(\frac{\mathrm{a}}{1-\mathrm{a}}\right)-\mathrm{R}
$$

where a is the ratio of the total tax paid to the total pre-tax income of all households combined (Creedy, 1999).

69. If no re-ranking of households occurs then $\mathrm{R}$ is zero and this measure can be refined to reflect the percentage contribution of each tax to the overall change in income inequality:

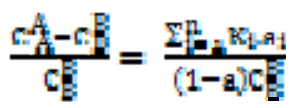

where $\mathrm{a}_{\mathrm{i}}$ and $\mathrm{K}_{\mathrm{i}}$ are the average tax rate (defined as the ratio of tax to income) and the progressivity index of the $i^{\text {th }}$ tax respectively, and a is the average tax rate for all taxes. The percentage contribution of each tax to the overall progressivity of the tax system can then be estimated from:

$$
\mathrm{K}=\sum_{i=1}^{t} \frac{\mathrm{a}_{1}}{\mathrm{a}} \cdot \mathrm{P}_{1}
$$

Of these measures, the Congressional Budget Office (1988) proposed that the Suits measure is the most commonly used. In more recent times, the full range of these measures is generally applied.

70. The limitations of Lorenz curve based measures are detailed by Creedy (2002). Probably the most profound limitation is that they are not explicit about the underlying social welfare function. Atkinson's (1970) generalized entropy measures had the advantage of making explicit how the experiences of different groups are weighted. The Gini index, for example, assumes a particular utility function (Atkinson, 1970; Sen, 1973) which weighs middle income ranges most heavily. Atkinson (1970) explicitly recognises this utility function by incorporating an inequality aversion parameter into his measure of inequality. However, this measure remains far less widely applied than Lorenz curve based measures (Kesselman and Cheung, 2004).

71. Despite the appeal of simple measures of inequality, by far the most common representation of tax incidence across households is through tabular presentation of tax incidence. In this representation, households are divided into equal groupings such as deciles, quintiles and quartiles. Results are then presented as either the ratio of tax to income (ATR) or in terms of the redistributive impact of taxes on some measure of income inequality. A criticism of this approach is that, while estimates of average incidence are interesting, they need to be complemented with estimates of marginal incidence, which involves examining changes in the burden as income increases - in effect a changing progressivity measure such as a change in liability progression (MTR/ATR) as income increases.

\subsection{Summing-up}

72. Many factors need to be specified prior to undertaking a study into the distributional impact of consumption taxes on households. Differing approaches to each of the issues raised lead to different findings from the same data sources. These differences must be appreciated prior to any analysis either of the results or their comparison across studies. 


\section{Findings from country studies of consumption tax incidence}

73. This section reviews selected empirical studies with a view to learning more about the approach taken to estimating consumption tax incidence in practice and comparing their findings. This is difficult, as available estimates are based on many different approaches, with different modelling frameworks, different data sources and coverage of taxes and households. As a result, this section provides only a cursory review of selected studies, referring the reader to the individual studies for further insight. The primary focus is on the approaches undertaken in a limited number of English speaking countries, how they differ, how their findings differ and what part could be attributed to differences in data and conceptual approaches. Also, for some studies, it is not possible to separate the effect of consumption taxes from that of other taxes and of public benefits. However, none of the studies reviewed here include consideration of deadweight losses, tax compliance and administration costs, tax gap or tax expenditures.

74. In this review, three key aspects of each study will be identified:

- The approach to modelling the shifting of consumption taxes to household.

- The measurement of household well being.

- The method of evaluating distributional impact of consumption taxes across households.

75. As will be noted below, a key driver determining the approach taken in addressing these three aspects of tax incidence studies is the purpose of the study, the data available and whether Government is directly involved in its preparation. In general, studies aimed at providing multi-country comparisons have a lesser level of precision than single country studies. Also, government-based studies generally benefit from a higher level of resourcing, in terms of both access to data and financial support. Section 4.1 distinguishes between government and non-government studies for a single country. Section 4.2 focuses on comparative studies based on the Luxembourg Income Study (LIS) ${ }^{17}$ project, on recent enhancements to the EUROMOD ${ }^{18}$ model, and to other multi-country studies.

76. The key methodological differences and basic findings from these studies are summarized in Table 1. The structure of the table reflects the issues raised in Section 3 as critical issues that all studies of the distributional impact of consumption taxes must address. These include the scope of the study, the range of consumption taxes covered, the modelling of intermediate taxes (A, B, C, D and E in Figure 6), the incidence approach (absolute or differential) used, the tax shifting assumptions and measure of welfare adopted. Attention is also drawn to differences in equivalence scales and whether a tax rate is applied to a household's consumption to determine their consumption tax liability or if the nominal tax burden for society as a whole is distributed across households based on their share of consumption of the taxed good. The distributional impact measures used to present the results are also noted including the use of tables and figures (presented using deciles or quintiles) and single number measures such as a Gini based measure or the Suits index. Findings from these various studies are contrasted using simple summary measures.

\subsection{Single-country studies}

77. It is quite common for governments to resource agencies to undertake research into tax incidence, or to sponsor research into this issue by non-government agencies, facilitated by their collation of data necessary to undertake such analysis. In some cases, this goes as far as to support the development of

\footnotetext{
17. $\quad<\mathrm{http}: / /$ www.lisproject.org/>

18. $\quad<$ http://www.iser.essex.ac.uk/msu/emod/> and in particular

$<$ http://www.iser.essex.ac.uk/msu/emod/workingpapers/em701.pdf>
} 
microsimulation models for the analysis of how current and prospective tax and welfare policies might impact on households. In single country studies, the important contribution of government studies will be clear. Amongst the English speaking OECD countries, the United Kingdom, Canada and Australia have all sponsored comprehensive studies or developed models which enable non-government researchers to study tax distributional issues (i.e. Canada). While there are some similarities in approach by these and other single country studies, there are also differences which help to explain the different findings.

\section{United Kingdom}

\section{Government Studies}

78. The UK ONS has been a pioneer in the estimation of the effect of taxes and benefits on household income. As early as 1957 it began making results available publicly and has so each year since. In additional to a detailed publication findings in ONS (2007), ${ }^{19}$ findings are also circulated more widely in the ONS publication Economic Trends. ${ }^{20}$

79. The ONS approach allocates those taxes to households which can be reasonably attributed to households. ${ }^{21}$ The ONS study covers, in terms of Figure $6, \mathrm{~A}+\mathrm{B}+\mathrm{C} 1+\mathrm{D} 1+\mathrm{E} 1$, i.e. around $70 \%$ of taxes into the production process. Results on the distributional impact of taxes on goods and services - whether on final demand or on intermediate inputs into the production and distribution process - indicate that consumption taxes represent around $30 \%$ of the disposable income of the bottom quintile, as compared to $14 \%$ for the top decile (Table 2 and Figure 9, panel a). The regressivity of consumption taxes is apparent, with VAT less regressive than excise duties, partly reflecting the zero VAT rate applied to food.

19. The ONS publication "The effects of taxes and benefits on household income, 2005/06" is downloadable from <http://www.statistics.gov.uk/cci/article.asp?id=1804>

20. See "The effects of taxes and benefits on household income, 2004/05" Economic Trends article which can be downloaded from

$<$ http://www.statistics.gov.uk/cci/article.asp?ID=1557\&Pos=2\&ColRank=1\&Rank=160>. However, from 2007 , this publication goes online and appears to no longer include a summary of the full publication.

21. See ONS (2007, p. 3) where it was stated that: "The analysis only allocates those taxes and benefits that can reasonably be attributed to households. Therefore, some government revenue and expenditure is not allocated such as revenue from corporation tax and expenditure on defence and public order. There are three main reasons for non-allocation. Some taxes and benefits fall on people who do not live in private households. In other cases, there is no clear conceptual basis for allocation to particular households. Finally, there may be a lack of data to enable allocation. In this study, some $£ 321$ billion of taxes and compulsory social contributions have been allocated to households. This is equivalent to $60 \%$ of general government expenditure, which totaled $£ 536$ billion in 2005 (Table 13). Similarly, $£ 288$ billion of cash benefits and benefits in kind have been allocated to households, making up 54\% of general government expenditure (Table 13)". 
Table 1. An overview of studies on the incidence of consumption taxes

\begin{tabular}{|c|c|c|c|c|c|c|c|c|c|c|c|}
\hline & \multirow{2}{*}{$\begin{array}{r}\text { Country/ } \\
\text { Multi - } \\
\text { country } \\
\text { databases }\end{array}$} & \multirow{2}{*}{$\begin{array}{r}\text { What } \\
\text { consumption } \\
\text { taxes are } \\
\text { included? }\end{array}$} & \multicolumn{5}{|c|}{ Tax modelling characteristics } & \multirow{2}{*}{$\begin{array}{r}\text { Equivalence } \\
\text { Scale } \\
\text { (1Adult } / 2+ \\
\text { Adults/ Each } \\
\text { Child) }\end{array}$} & \multirow{3}{*}{$\begin{array}{r}\text { Tax rates } \\
\text { or nominal } \\
\text { tax } \\
\text { approach? }\end{array}$} & \multirow{2}{*}{$\begin{array}{r}\text { Distributional } \\
\text { impact } \\
\text { presentation }\end{array}$} & \multirow[t]{2}{*}{ Main results } \\
\hline & & & $\begin{array}{r}\text { Using notation in } \\
\text { Figure } 6\end{array}$ & $\begin{array}{r}\text { How are } \\
\text { intermediate } \\
\text { taxes } \\
\text { modelled } \\
\text { (B/C/D/E in } \\
\text { Figure 6) }\end{array}$ & $\begin{array}{l}\text { Incidence } \\
\text { approach }\end{array}$ & $\begin{array}{l}\text { What Tax shifting } \\
\text { assumptions? }\end{array}$ & $\begin{array}{r}\text { What } \\
\text { measure of } \\
\text { welfare (as } \\
\text { indicated in } \\
\text { Figure 7) }\end{array}$ & & & & \\
\hline \multicolumn{11}{|c|}{ SINGLE COUNTRY STUDIES } & \\
\hline $\begin{array}{l}\text { Harding, Lloyd } \\
\text { and Warren }\end{array}$ & Australia & All & $\mathrm{A}+\mathrm{B}+\mathrm{C} 2+\mathrm{D} 2+\mathrm{E} 1$ & I-O model & Absolute & Fully forward & $\mathrm{A} / \mathrm{B}$ & $1 / .5 / .3$ & Tax rates & $\begin{array}{l}\text { Decile, Gini, } \\
\text { Tabular }\end{array}$ & $\begin{array}{r}\text { Quintile 5/1: VAT/Excise: }= \\
0.38\end{array}$ \\
\hline & & & & & & & & & & & $\begin{array}{l}\text { 93\% Taxes on Production } \\
\text { allocated to individuals }\end{array}$ \\
\hline ONS (2007a) & UK & All & $\mathrm{A}+\mathrm{B}+\mathrm{C} 1+\mathrm{D} 1+\mathrm{E} 1$ & I-O model & Absolute & Fully forward & $\mathrm{A} / \mathrm{B} / \mathrm{C} / \mathrm{D} / \mathrm{E}$ & See Table 2 & Tax rates & $\begin{array}{r}\text { Quintile, } \\
\text { Tabular, Gini }\end{array}$ & $\begin{array}{r}\text { Quintile 5/1: VAT 0.58, Excise } \\
0.37, \text { VAT/Excise } 0.49\end{array}$ \\
\hline $\begin{array}{l}\text { IFS } \\
\text { Budget } \\
\text { Myck (2000) }\end{array}$ & UK & Fuel Duty & A & Not modelled & Differential & Fully forward & $\mathrm{C}$ & $\begin{array}{r}\text { Modified } \\
\text { OECD } \\
\text { equivalence } \\
\text { scale: }\end{array}$ & Tax rates & Figures & $\begin{array}{l}\text { Differential results are not } \\
\text { directly comparable to absolute } \\
\text { incidence estimates. Quintile } \\
5 / 1 \text { : Fuel Duty } 0.61 \text {, Indirect } \\
\text { tax reforms 1997-2001 } 0.39\end{array}$ \\
\hline $\begin{array}{l}\text { Congressional } \\
\text { Budget } \quad \text { Office }\end{array}$ & US & $\begin{array}{r}\text { Federal } \\
\text { consumption }\end{array}$ & $\begin{array}{r}\mathrm{A}+\mathrm{B}+\mathrm{C} 2+\mathrm{D} 2+\mathrm{E} 2 \\
(\text { Taxes on }\end{array}$ & $\begin{array}{r}\text { A is allocated } \\
\text { direct to }\end{array}$ & Absolute & Fully forward & B & $\begin{array}{l}\text { Square root of } \\
\text { household size }\end{array}$ & $\begin{array}{r}\text { Nominal tax } \\
\text { distributed }\end{array}$ & Tabular & $\begin{array}{r}\text { Quintile 5/1: Federal Excise: }= \\
0.24 \text { in } 2004\end{array}$ \\
\hline (2007) & & taxes & $\begin{array}{r}\text { intermediate } \\
\text { goods borne in } \\
\text { proportion to their } \\
\text { overall } \\
\text { consumption.) }\end{array}$ & $\begin{array}{r}\text { individuals } \\
\text { and }(\mathrm{B}+\mathrm{C}+\mathrm{E}) \\
\text { on the basis of } \\
\text { share in total } \\
\text { consumption }\end{array}$ & & & & & $\begin{array}{r}\text { according to } \\
\text { consumption } \\
\text { of the taxed } \\
\text { good or } \\
\text { service }\end{array}$ & & $\begin{array}{r}100 \% \text { Taxes on Production } \\
\text { allocated to individuals }\end{array}$ \\
\hline
\end{tabular}




\begin{tabular}{|c|c|c|c|c|c|c|c|c|c|c|c|}
\hline & \multirow{2}{*}{$\begin{array}{r}\text { Country/ } \\
\text { Multi - } \\
\text { country } \\
\text { databases }\end{array}$} & \multirow{2}{*}{$\begin{array}{r}\text { What } \\
\text { consumption } \\
\text { taxes are } \\
\text { included? }\end{array}$} & \multicolumn{5}{|c|}{ Tax modelling characteristics } & \multirow{2}{*}{$\begin{array}{r}\text { Equivalence } \\
\text { Scale } \\
\text { (1Adult/2+ } \\
\text { Adults/ Each } \\
\text { Child) }\end{array}$} & \multirow{2}{*}{$\begin{array}{r}\text { Tax rates } \\
\text { or nominal } \\
\text { tax } \\
\text { approach? }\end{array}$} & \multirow{2}{*}{$\begin{array}{r}\text { Distributional } \\
\text { impact } \\
\text { presentation }\end{array}$} & \multirow[t]{2}{*}{ Main results } \\
\hline & & & $\begin{array}{r}\text { Using notation in } \\
\text { Figure } 6\end{array}$ & $\begin{array}{r}\text { How are } \\
\text { intermediate } \\
\text { taxes } \\
\text { modelled } \\
\text { (B/C/D/E in } \\
\text { Figure 6) }\end{array}$ & $\begin{array}{l}\text { Incidence } \\
\text { approach }\end{array}$ & $\begin{array}{r}\text { What Tax shifting } \\
\text { assumptions? }\end{array}$ & $\begin{array}{r}\text { What } \\
\text { measure of } \\
\text { welfare (as } \\
\text { indicated in } \\
\text { Figure 7) }\end{array}$ & & & & \\
\hline $\begin{array}{l}\text { Chamberlain } \\
\text { and Prante } \\
\text { (2007) (Tax } \\
\text { Foundation) }\end{array}$ & US & $\begin{array}{r}\text { Federal } \\
\text { Excise and } \\
\text { Customs, } \\
\text { State Sales } \\
\text { Tax }\end{array}$ & $\mathrm{A}+\mathrm{B}+\mathrm{C} 2+\mathrm{D} 2+\mathrm{E} 2$ & $\begin{array}{r}\text { Not modelled; } \\
\text { allocated in } \\
\text { aggregate to } \\
\text { household } \\
\text { overall } \\
\text { consumption }\end{array}$ & Absolute & $\begin{array}{r}\text { Sales Tax and } \\
\text { Customs Duties to } \\
\text { consumers but } \\
\text { Diesel Excise split } \\
\text { between consumers } \\
\text { and corporate tax } \\
\text { allocation approach }\end{array}$ & B & $\begin{array}{l}\text { "Each quintile } \\
\text { contains equal } \\
\text { numbers of } \\
\text { people, and } \\
\text { thus unequal } \\
\text { numbers of } \\
\text { households" } \\
\text { p16 }\end{array}$ & Nominal tax & $\begin{array}{r}\text { Tabular, Suits } \\
\text { Index }\end{array}$ & $\begin{array}{r}\text { Quintile 5/1: Federal Excise: } \\
0.87 \text {, Federal Customs 0.59, } \\
\text { State Sales 0.76, State Excise } \\
0.59 \text {, Total } 0.74 \\
\text { 100\% Taxes on Production } \\
\text { allocated to individuals }\end{array}$ \\
\hline $\begin{array}{l}\text { McIntyre, } \\
\text { Denk, Francis, } \\
\text { Gardner, } \\
\text { Gomaa, Hsu, } \\
\text { and Sims } \\
\text { (2003) (ITEP) }\end{array}$ & US & $\begin{array}{r}\text { State Sales } \\
\text { and Excise } \\
\text { Taxes }\end{array}$ & $\begin{array}{r}\mathrm{A}+\mathrm{B}+\mathrm{C} 2+\mathrm{D} 2+\mathrm{E} 2 \\
(\text { Exporting } \\
\text { between states } \\
\text { modelled but } \\
\text { appears all taxes } \\
\text { ultimately } \\
\text { allocated to } \\
\text { residents) }\end{array}$ & $\begin{array}{r}\text { I-O model } \\
\text { with taxes on } \\
\text { intermediate } \\
\text { inputs \& } \\
\text { capital } \\
\text { Investment } \\
\text { allocated) }\end{array}$ & Absolute & Fully forward & $\begin{array}{r}\text { B } \\
\text { (but including } \\
\text { only non- } \\
\text { elderly families } \\
\text { (singles and } \\
\text { couples, with } \\
\text { and without } \\
\text { children)) }\end{array}$ & $\begin{array}{r}\text { Ranking of } \\
\text { families into } \\
\text { quintile } \\
\text { without } \\
\text { apparent } \\
\text { adjustment }\end{array}$ & Tax rates & Tabular & $\begin{array}{l}\text { Quintile 5/1: State General } \\
\text { Sales-Individuals 0.45; Other } \\
\text { State Sales \& Excise- } \\
\text { Individuals } 0.23 \text {; State Sales \& } \\
\text { Excise on Business 0.32; All } \\
\text { Sales \& Excise Taxes } 0.36 \\
\text { 100\% Taxes on Production } \\
\text { allocated to individuals }\end{array}$ \\
\hline $\begin{array}{l}\text { Vermaeten, } \\
\text { Gillespie and } \\
\text { Vermaeten } \\
\text { (1995) }\end{array}$ & Canada & All & $\mathrm{A}+\mathrm{B}+\mathrm{C} 2+\mathrm{D} 2+\mathrm{E} 1$ & $\begin{array}{r}\text { Not modelled } \\
\text { (allocated } \\
\text { direct to } \\
\text { household } \\
\text { consumption) }\end{array}$ & Absolute & $\begin{array}{r}\text { Commodity taxes } \\
\text { are borne by } \\
\text { consumers, except } \\
\text { for the share of } \\
\text { such taxes on } \\
\text { government } \\
\text { purchases which is } \\
\text { borne by personal } \\
\text { income taxpayers } \\
\text { and the share on } \\
\text { purchases of capital } \\
\text { goods and exports, } \\
\text { the common } \\
\text { portion of which is } \\
\text { borne by consumers } \\
\text { and the differential } \\
\text { portion of which is } \\
\text { borne by labour. }\end{array}$ & $\begin{array}{r}\text { Three different } \\
\text { definitions of B } \\
\text { are applied }\end{array}$ & $\begin{array}{l}\text { Square root of } \\
\text { household size }\end{array}$ & Nominal tax & $\begin{array}{l}\text { Tabular, } \\
\text { Figures }\end{array}$ & $\begin{array}{r}\text { Quintile 5/1: Commodity } \\
\text { taxes: } 0.60 \\
\text { Taxes on Production allocated } \\
\text { to non-residents according to } \\
\text { exports and ownership of factor } \\
\text { bearing taxes by non-residents }\end{array}$ \\
\hline
\end{tabular}




\begin{tabular}{|c|c|c|c|c|c|c|c|c|c|c|c|}
\hline & \multirow{2}{*}{$\begin{array}{r}\text { Country/ } \\
\text { Multi - } \\
\text { country } \\
\text { databases }\end{array}$} & \multirow{2}{*}{$\begin{array}{r}\text { What } \\
\text { consumption } \\
\text { taxes are } \\
\text { included? }\end{array}$} & \multicolumn{5}{|c|}{ Tax modelling characteristics } & \multirow{2}{*}{$\begin{array}{r}\text { Equivalence } \\
\text { Scale } \\
\text { (1Adult/2+ } \\
\text { Adults/ Each } \\
\text { Child) }\end{array}$} & \multirow{2}{*}{$\begin{array}{r}\text { Tax rates } \\
\text { or nominal } \\
\text { tax } \\
\text { approach? }\end{array}$} & \multirow{2}{*}{$\begin{array}{r}\text { Distributional } \\
\text { impact } \\
\text { presentation }\end{array}$} & \multirow[t]{2}{*}{ Main results } \\
\hline & & & $\begin{array}{r}\text { Using notation in } \\
\text { Figure } 6\end{array}$ & $\begin{array}{r}\text { How are } \\
\text { intermediate } \\
\text { taxes } \\
\text { modelled } \\
\text { (B/C/D/E in } \\
\text { Figure 6) }\end{array}$ & $\begin{array}{l}\text { Incidence } \\
\text { approach }\end{array}$ & $\begin{array}{r}\text { What Tax shifting } \\
\text { assumptions? }\end{array}$ & $\begin{array}{r}\text { What } \\
\text { measure of } \\
\text { welfare (as } \\
\text { indicated in } \\
\text { Figure 7) }\end{array}$ & & & & \\
\hline $\begin{array}{l}\text { Duessing } \\
\text { (2003) }\end{array}$ & Canada & $\begin{array}{r}\text { Federal } \\
\text { Excise and } \\
\text { VAT }\end{array}$ & $\mathrm{A}+\mathrm{B}+\mathrm{C} 1+\mathrm{D} 1+\mathrm{E} 1$ & I-O model & Absolute & Fully forward & $\begin{array}{r}\text { Family total } \\
\text { income }\end{array}$ & $\begin{array}{r}\text { No apparent } \\
\text { adjustment }\end{array}$ & Tax rates & $\begin{array}{l}\text { Tabular, } \\
\text { Figures }\end{array}$ & $\begin{array}{r}\text { Results are presented by family } \\
\text { income ranges }\end{array}$ \\
\hline $\begin{array}{l}\text { Barrett and } \\
\text { Wall (2005) }\end{array}$ & Ireland & $\begin{array}{r}\text { VAT and } \\
\text { Excise? }\end{array}$ & A & Not modelled & Absolute & Fully forward & B & $1 / .66 / .33$ & $\begin{array}{r}\text { Nominal } \\
\text { tax } \\
\text { allocated by } \\
\text { related } \\
\text { expenditure }\end{array}$ & $\begin{array}{l}\text { Tabular, } \\
\text { Figures }\end{array}$ & $\begin{array}{r}\text { Quintile 5/1: VAT 0.63; Excise } \\
0.56 ; \text { VAT/Excise } 0.61\end{array}$ \\
\hline \multicolumn{12}{|c|}{ MULTIPLE COUNTRY STUDIES } \\
\hline $\begin{array}{l}\text { Garfinkel, } \\
\text { Rainwater and } \\
\text { Smeeding(2006) }\end{array}$ & LIS & $\begin{array}{l}\text { VAT and } \\
\text { Excise }\end{array}$ & A & $\begin{array}{r}\text { Not modelled } \\
\text { (allocated } \\
\text { direct to HH } \\
\text { consumption) }\end{array}$ & Absolute & Fully forward & $\mathrm{C}, \mathrm{E}$ & $\begin{array}{r}\text { Square root of } \\
\text { household size }\end{array}$ & Tax rates & $\begin{array}{l}\text { Tabular, } \\
\text { Figures }\end{array}$ & See Table 4 \\
\hline $\begin{array}{l}\text { Harding, Lloyd } \\
\text { and Warren } \\
(2007)\end{array}$ & \multicolumn{7}{|c|}{ See ONS(2006) and Harding, Lloyd and Warren (2006) } & & & & \\
\hline $\begin{array}{l}\text { O'Donoghue, } \\
\text { Baldini and } \\
\text { Mantovani } \\
\text { (2004) }\end{array}$ & $\begin{array}{r}\text { EUROM } \\
\text { OD } \\
\text { countries }\end{array}$ & & A & Not modelled & Absolute & Fully forward & $\mathrm{C}$ & & Tax rates & $\begin{array}{l}\text { Tabular, } \\
\text { Figures }\end{array}$ & See Tables 5 and 6 \\
\hline
\end{tabular}


Figure 9. Consumption tax incidence in Australia, Canada, Ireland and the United Kingdom

a. UK: Average incomes, taxes and benefits by quintile groups of all households, 2005/06

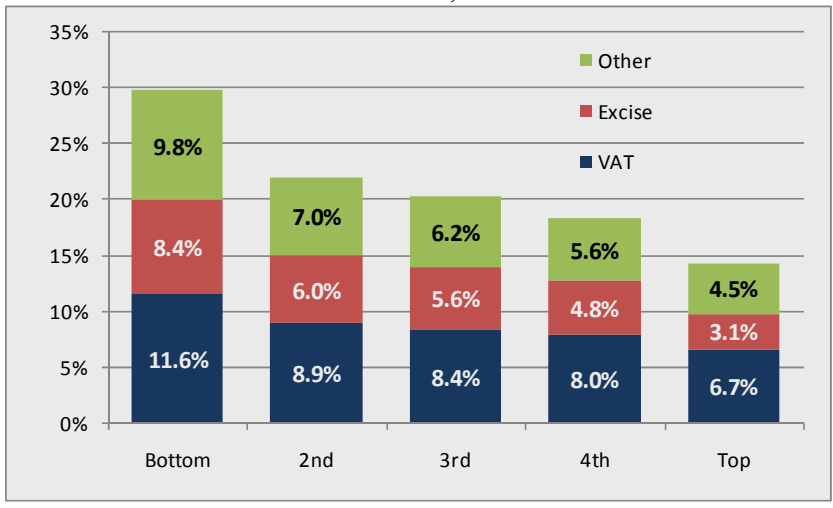

b. Australia 2001-02

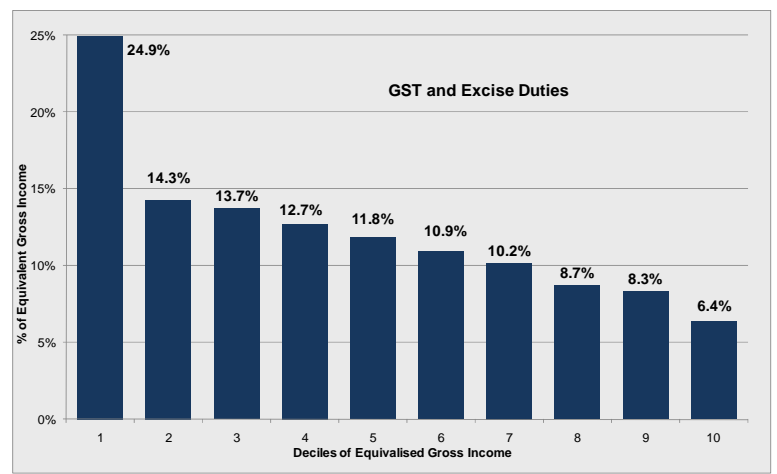

Source: Harding, Lloyd and Warren (2005), Figure 1

Source: ONS (2007), Appendix 1, Table 14A

c. Australia 2003-04

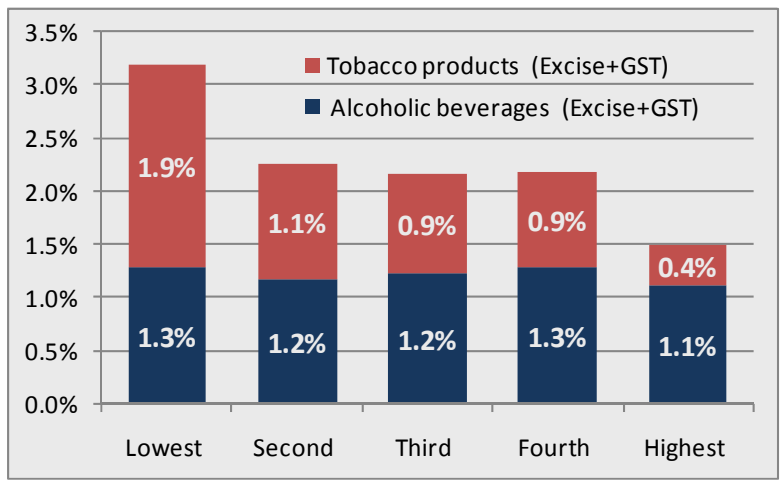

Source: ABS 2006, Cat No 6537.0 2003-04, Table 5

d. Canada 2000: Distributional impact of Federal indirect taxes and GST tax credits indirect taxes and GST Credits

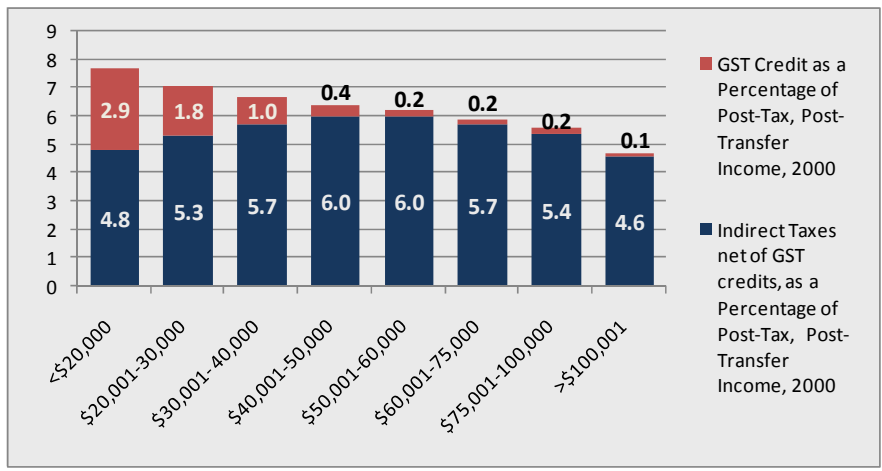

Source: Deussing (2003), Table 5, 11 and 12

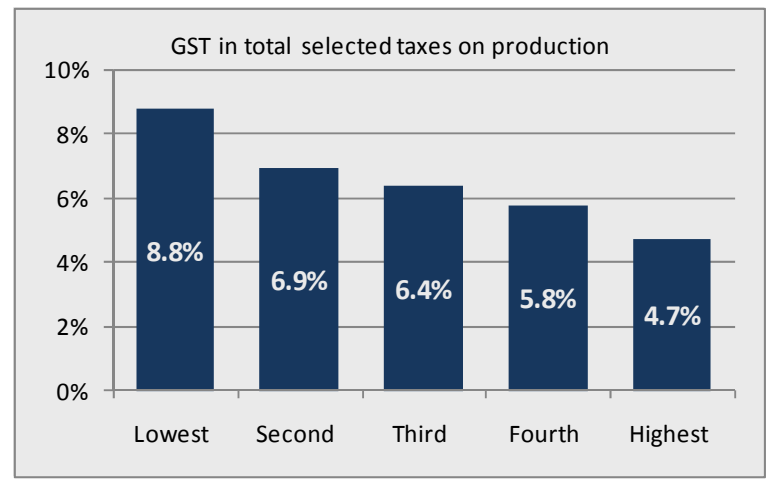

e. Canada 1988: Commodity taxes

f. Ireland: VAT 2004: Excise and VAT paid by equivalised income decile

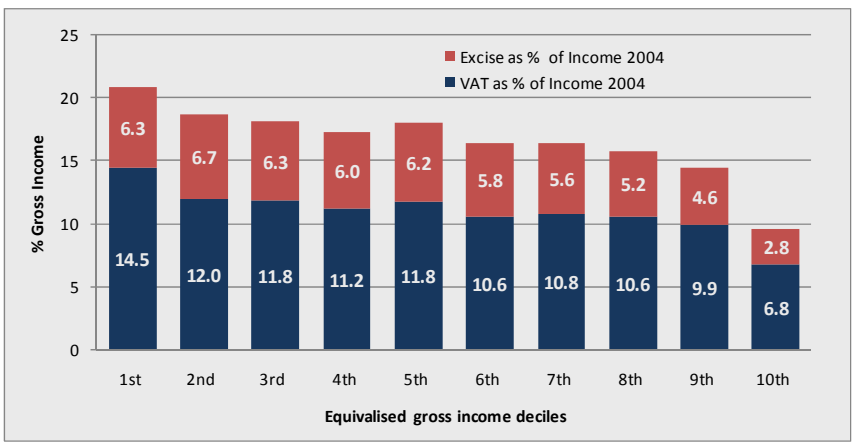

Source: Barrett and Wall (2005), Table 3.

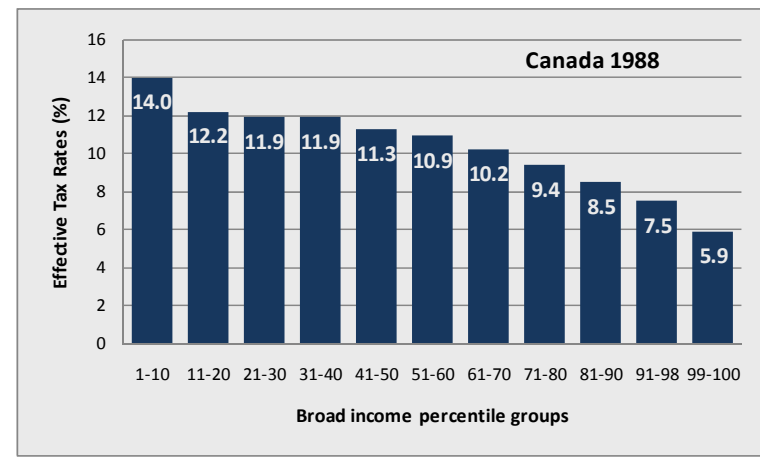

Source: Vermaeten, Gillespie and Vermaeten (1995) 
80. Table 2 details the equivalence scale ${ }^{22}$ applied in the ONS study and the impact of all taxes on various measures of income and income inequality - but does not report specific results for consumption taxes. The ONS report is static and based on an absolute incidence approach, implying that its model has limited scope to inform policy making.

Table 2. The effects of taxes and benefits on household income in the United Kingdom, 2005-06

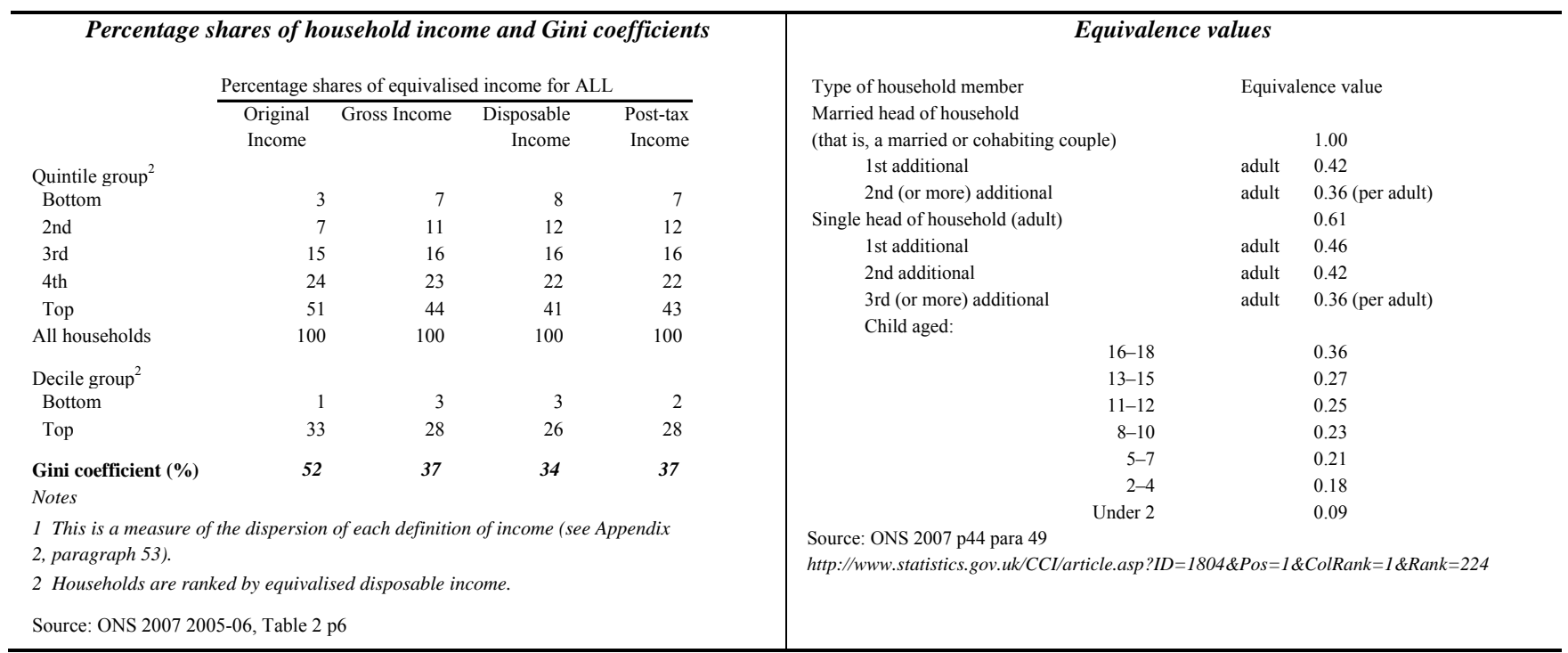

\section{Non-Government Studies}

81. One of the most developed microsimulation models used to estimate differential tax incidence is the one developed by the Institute for Fiscal Studies (IFS). In addition to the basic model TAXBEN, IFS have also developed extensions to examine VAT and excise incidence. Behavioural response of consumers to relative price changes due to consumption tax reforms ${ }^{23}$ were considered in earlier studies (Symons and Warren, 1996) but are no longer maintained.

82. Results from modelling of VAT and excise duties in association with TAXBEN are often presented in the annual IFS Green Budget analysis. For example, the 2005 volume investigated the distributional effects of all tax and benefit reforms since $1997^{24}$ while that of 2007 examined the distributional impact of reforms of environmental taxes (in the form of a 5\% increase in fuel excise duty, finding that its distributional impact is almost proportional across deciles 2 to 9 , but higher than average on the bottom and the top deciles). ${ }^{25}$ Using the same modelling framework used in the Green Budgets, Myck

22. The UK government is using the modified OECD scale to adjust incomes (see Appendix 3 of Households Below Average Income 1994/95-2004/05 or Appendix A of M. Brewer, A. Goodman, J. Shaw and L. Sibieta, Poverty and Inequality in Britain: 2006, IFS Commentary 101, 2006).

23. See $<$ http://cemmap.ifs.org.uk/events.php?event_id=197>

24. See Chapter 7 in IFS Green Budget $2005<$ http://www.ifs.org.uk/budgets/gb2005/>

25. See Source; IFS Green Budget 2007, Chapter 11, Figure 11.6, p. 206.

$<\mathrm{http}: / /$ www.ifs.org.uk/budgets/gb2007/> 
(2000) find that changes in consumption taxes introduced between 1997 and 2000 increased income inequality. ${ }^{26}$

83. The IFS now adopts the OECD modified equivalence scale, which is marginally different from that used by Myck (2000). ${ }^{27}$ However, since the IFS results relate to tax changes (or differential incidence estimates) they have limited comparability with those from ONS (absolute incidence). Also, the IFS results do not adequately model $\mathrm{A}$ and $\mathrm{C}$ in Figure 6 . As with most other studies, the IFS methodology assumes full shifting forward of consumption taxes - not allowing for behavioural responses and ignoring the effect of such taxes on intermediate inputs. The household data used in the IFS study is, as with the ONS (2007a) study, the UK Expenditure and Food Survey (EFS) ${ }^{28}$

\section{Australia}

\section{Government Studies}

84. The Australian Bureau of Statistics began preparing official estimates of the impact of government benefits and taxes on households in 1987 for the year 1984 (ABS, 2006) based on the same methodological approach as adopted by ONS in its UK study. With each release of new Household Expenditure Survey (HES), ABS has subsequently released new estimates which are available for the fiscal years 1988-89, 1993-94, 1998-99 and 2003-04. In terms of Figure 6, the ABS approach models $\mathrm{A}+\mathrm{B}+\mathrm{C} 1+\mathrm{D} 1+\mathrm{E} 1$, i.e. including only those taxes that are levied either directly on final consumption of households, or on business investment and on intermediate inputs into these final consumption expenditures. As a result, some $60 \%$ of total taxes on production (ABS, 2006, Cat 6537, Table A4.1, p. 86) are allocated to domestic household final demand. If taxes on foreign households final demand (through exports) and on government (which can be viewed as churning) are regarded as not incident on domestic households (D1 and E1), then the proportion allocated is greater.

85. Figure 9 (panel c) details the basic findings of this study in relation to consumption taxes with households ranked by household disposable income equivalised with the 'modified OECD' scale (ABS, 2006, p. 79). The study presents the results by various social-economic and demographic groupings as well as the ratio of income in various deciles to that in other deciles (e.g. Percentile 90/Percentile 10 in ABS, 2006, p. 17) but no single measure of inequality. Individual consumption taxes are not identified but the GST component of total taxes on production for the fifth quintile was 0.54 of that for the first quintile.

\section{Non-Government Studies}

86. Non-government studies have been undertaken by Harding, Lloyd and Warren (2006) using the STINMOD-STATAX microsimulation model. ${ }^{29}$ STINMOD allocates personal income taxes and social

26. Myck (2000) concludes that "changes to consumption taxes since July 1997 have had a negative impact on post-tax incomes across the whole income range, with the most pronounced effects being among the poorest households. On average the effect of reduced VAT on domestic fuel has been outweighed by increases in excise duties on tobacco and road fuel for households in all 10 deciles".

27. In terms of equivalence scales adopted by the IFS and UK government see Appendix 3 of the IFS report prepared for the Department of Work and Pensions "Households Below Average Income (HBAI) 1994/952004/05" 2006 report at <http://www.policyhub.gov.uk/news_item/poverty_ifs06.asp > and <http://www.dwp.gov.uk/asd/hbai/hbai2005/pdf_files/appendices/appendix_3_hbai06.pdf>

28. See details of the ONS Family Expenditure and Food Survey at $<\mathrm{http}$ //www.statistics.gov.uk/StatBase/Product.asp?vlnk=361\&Pos=1\&ColRank=1\&Rank=272>

29. See <http://www.canberra.edu.au/centres/natsem/research/research_areas/tax-reform-stinmod-statax $>$ and NATSEM Technical Paper - TP16. 
welfare payments to households, while STATAX uses input-output data to model the forward shifting of all consumption taxes to domestic and foreign households (i.e. $\mathrm{A}+\mathrm{B}+\mathrm{C}$ in Figure 6). Lambert and Warren (1999) detailed this model and the estimation of the consumption tax rates applied to unit record Australian Household Expenditure Data.

87. At its simplest, the first phase in STATAX is to identify the consumption tax component in the price of various goods. This is achieved by constructing an Input-Output Price Model using data prepared by the Australian Bureau of Statistics. ${ }^{30}$ In terms of Figure 6, all consumption taxes $(\mathrm{A}+\mathrm{B}+\mathrm{C} 2+\mathrm{D} 2+\mathrm{E} 1)$ are assumed to be shifted forward to domestic or foreign households. This model for allocating taxes to households has been applied in two variants. Warren $(1979,1983$, and 1998) allocated aggregate taxes to households along with aggregate income using household income and expenditure shares observed in household surveys. In contrast, Harding et al. $(2005,2006,2007)$ relied on the conversion of national accounts tax aggregates into 'effective tax inclusive tax rates' which are then applied to the household unit record data used by STINMOD.

88. These two approaches can yield different results. For example, if expenditure on alcohol is underreported in household surveys, the effective tax rate approach applies the rate to the underreported expenditure and therefore under-allocates the tax on alcohol. In contrast, the approach based on tax aggregates will allocate all the tax on alcohol regardless of the total underreporting or how this differs between groups. Each approach will therefore result in quite different distributional impact estimates for taxes on alcohol.

89. Just as underreporting of expenditure on items can lead to very different tax incidence patterns from the two approaches, underreporting of any particular income source would similarly distort results. Furthermore, in contrast to microsimulation models (based on household unit record data), the income assigned to households includes not only cash income but also imputed elements such imputed rents, imputed interest and insurance income, retained profits, company taxes (on dividends), other taxes (on dividends), and supplements to wages and salaries (Warren, 1997, Table 3, p. 672).

90. Since the Harding, Lloyd and Warren (2006) study is concerned with evaluating the distributional impact of consumption tax reforms introduced in July 2000 across households using the STINMODSTATAX microsimulation model, STATAX was used to estimate the effective consumption tax rates on a range of commodities in HES as a result of the reforms introduced in July $2000 .{ }^{31}$ This package of reforms was not revenue neutral and reduced households' overall tax liability. Figure 9 (panel b) shows the findings for GST and Excise duties across deciles of equivalised individuals ranked by gross income. The impact of these taxes on the lowest decile is nearly four times that for the highest decile: when adjusting the results to quintiles, the experience for the lowest quintile is around 2.5 times as high as that for the highest quintile.

91. Using the same equivalence scale used in the ABS study (1/0.5/0.3), Table 3 outlines findings for Gini index based inequality measures. The progressivity of the personal income tax is apparent as is the regressivity of consumption taxes. Not including consumption taxes when examining the impact of government on individuals will therefore result in a more progressive distributional impact than in fact is the case.

30. Australian National Accounts: Input Output 1993-94, ABS Cat No. 5209.0, Australian Bureau of Statistics.

31. Other microsimulation models have found application to the study of the distributional impact of consumption taxes in Australia. The Australian Federal Treasury developed PRISMOD (Henry and Wright, 1992) for the analysis of 1985 and 1998 consumption tax reforms. Scutella (1999) detailed an input-output consumption tax model which was applied by Creedy (2002) to the study of vertical and horizontal equity of the consumption tax reforms introduced in Australia in July 2000. 
Table 3. The impact of the tax system on income distribution in Australia

\begin{tabular}{|c|c|c|c|c|c|}
\hline & $\begin{array}{r}\text { Personal } \\
\text { Income Tax } \\
(\mathrm{PIT})\end{array}$ & $\begin{array}{r}\text { GST and } \\
\text { Excise Duties }\end{array}$ & Other Taxes & $\begin{array}{r}\text { All Taxes } \\
\text { excl PIT }\end{array}$ & All Taxes \\
\hline ATR & 19.5 & 9.7 & 15.9 & 25.6 & 45.1 \\
\hline $\mathrm{G}^{*}$ & 0.3029 & 0.3763 & 0.3702 & 0.3945 & 0.3274 \\
\hline $\mathrm{G}^{*}-\mathrm{G}$ & -0.0547 & 0.0187 & 0.0126 & 0.0369 & -0.0302 \\
\hline$\% \mathrm{G}$ & -22.5 & 8.6 & 5.4 & 14.0 & -8.5 \\
\hline $\mathrm{P}$ & 0.2256 & -0.1737 & -0.0667 & -0.1072 & 0.0368 \\
\hline$\% \mathrm{P}$ & 265.4 & -101.4 & -63.9 & -165.2 & 100.0 \\
\hline \multicolumn{6}{|c|}{ Ratio of Decile's ATR } \\
\hline $9 / 1$ & 29.95 & 0.33 & 0.44 & & 0.78 \\
\hline $5 / 1$ & 18.66 & 0.47 & 0.55 & & 0.76 \\
\hline $9 / 5$ & 1.60 & 0.71 & 0.80 & & 1.03 \\
\hline \multicolumn{6}{|l|}{ Notes } \\
\hline $\mathrm{G}^{*}$ & \multicolumn{5}{|c|}{ Gini index of post (selected) tax Income } \\
\hline G & \multicolumn{5}{|c|}{ Gini index of Gross Income (pre-tax) } \\
\hline G 2001-02 & \multicolumn{5}{|l|}{0.3576} \\
\hline $\mathrm{G}^{*}-\mathrm{G}$ & \multicolumn{5}{|c|}{ Gini Index of post-tax income less Gini Index of pre-tax income } \\
\hline$\% \mathrm{G}$ & \multicolumn{5}{|c|}{ Contribution to $\%$ change in post-tax Gini index } \\
\hline $\mathrm{P}$ & \multicolumn{5}{|c|}{ Progressivity index (Concentration index of taxes) } \\
\hline$\% \mathrm{P}$ & \multicolumn{5}{|c|}{ Percentage contribution to tax progressivity } \\
\hline
\end{tabular}

Source: Harding, Lloyd and Warren (2005), Table 13.

\section{Canada}

Government Studies

92. Canada's Social Policy Simulation Database and Model (SPSD/M) is a static microsimulation model that combines individual administrative data from Revenue Canada's sample of T1 personal income tax returns and employment insurance claimant histories, with data from the Survey of Consumer Finance (SCF), the Survey of Household Spending (SHS) and the Survey of Income and Labour Dynamics (SLID) on family incomes and expenditures. This model is maintained by Statistics Canada ${ }^{32}$ and made available for the modelling of tax and welfare policies - being just one of a number of microsimulation models developed by Statistics Canada. ${ }^{33}$ The SPSD/M model is sophisticated in its modelling of consumption taxes ${ }^{34}$ based on input-output data and the reallocation of consumption taxes on non-household final demand to households (i.e. $\mathrm{A}+\mathrm{B}+\mathrm{C} 1+\mathrm{D} 1+\mathrm{E} 1$ in Figure 6). However, the model omits consumption taxes levied at the provincial level.

93. Surprisingly little use has been made of SPSD/M in the evaluation of the overall incidence of consumption taxes - its use being primarily for the study of personal income tax and social welfare programs and their reform. Deussing (2003) used SPSD/M to analyse the impact on families of Federal taxes and transfers, including Federal custom import duties, excise duties, excise taxes, other energy taxes,

32. See $<$ http://www.statcan.ca/english/spsd/spsdm.htm $>$ and $<\mathrm{http}$ ://www.statcan.ca/bsolc/english/bsolc?catno=89F0002XCB $>$. This model is then made available to various users for a fee such as University students to model tax and social policy eg $<$ http://library.queensu.ca/webdoc/ssdc/cdbksnew/spsdm/spsdm.htm>

33. $\quad$ See $<$ http://www.statcan.ca/english/spsd/>

34. This is modelled in COMTAX which is a module in SPSD/M. A detailed explanation of the operation of this model is available in the documentation downloadable from the Statistics Canada website at $<$ http://www.statcan.ca/cgi-bin/Seds/form.cgi?file=spsmhelpe.exe> 
and the Federal GST, with results reported for family income groups. ${ }^{35}$ While this study omits provincial consumption taxes, it considers the GST credit designed to compensate low income groups for the adverse effects of the GST. The ability of this credit to offset the regressive impact of GST shown in Figure 9 (panel d) highlights the importance of including both the tax and expenditures in studies on the incidence of consumption taxes. For people in 2000 with incomes less than $\mathrm{C} \$ 20,000$, their Federal indirect tax burden pre-GST credit was some $64 \%$ higher than for people with incomes over C $\$ 100,000$; when including the GST credit, however, this difference is reduced to just $4 \%$. This observation highlights the importance of including all taxes, tax credits and welfare payments when examining the adverse distributional effects of a GST. This could be particularly relevant if the welfare payments and personal income tax system is designed to address the regressivity of these consumption taxes - hence the exclusion of the latter may yield a progressive distributional outcome never intended.

\section{Non-Government Studies}

94. Canada has a long history of tax incidence studies undertaken outside government. ${ }^{36}$ Two basic approaches characterized most studies. One is that adopted by Gillespie et al. which relies on allocating national account aggregates of income and taxes to families (or households) using data on the distributional patterns evident in household income, expenditure and finance surveys. The results from this approach, which is akin to that used by Warren $(1979,1997)$ for Australia, were applied to the situation in 1988 by Vermaeten, Gillespie and Vermaeten (1995) and are shown in Figure 9 (panel e). The second approach includes those based around the use of SPSD/M model which involves estimated tax rates being applied to household survey data with the potential for less than comprehensive allocation to household of all taxes collected. For Canada, as observed by Kesselman and Cheung (2004, pp. 779-780), the problem is that "almost all studies... are now quite dated, relying on data sets from the 1970s and 1980s. Few capture the major PIT reforms in Canada of 1988, the adoption of the GST in 1991, or the increasing use of payroll taxes since 1990".

\section{Ireland}

95. Barrett and Wall (2005) present results from a study undertaken for the Combat Poverty Agency to better understand the distributional impact of consumption taxes on those with low incomes. ${ }^{37}$ With a focus only on taxation, this study used gross (rather than net) income and the household as the unit of study (with an equivalence where the first adult is weighted as 1, all other adults are given a weight of 0.66 and each child is weighted as 0.33). Data on spending patterns was taken from the Ireland Central Statistics Office Household Budget Survey 1999/2000 and information on consumption taxes from the Irish Revenue Commissioners and the Department of Finance. The method for determining the incidence of VAT and excise taxes on household expenditure relied on information on the VAT and excise rates applied to each of the different goods and services identified in the survey data, and this was applied to household

35. It is also unclear if family income has been adjusted for family size (see Statistics Canada publication, Income in Canada 2005, Catalogue no. 75-202-XIE. <http://www.statcan.ca/bsolc/english/bsolc?catno=75202-X> . In other Statistics Canada publications, the equivalence scale used gives a weight of 1 to the oldest person in the family, 0.4 for the second oldest person, 0.4 for all other family members aged 16 and over and 0.3 for all other family members under age 16 .

36. At the vanguard of this Canadian research has been Irwin Gillespie who undertook such a study for the Royal Commission on Taxation in 1966 into "The Incidence of Taxes and Public Expenditures in the Canadian Economy". See Kesselman and Cheung (2004) for a comprehensive review of tax incidence studies in Canada.

37. See $<$ http://www.esri.ie/publications/search_for_a_publication/search_results/view/index.xml?id=2076> 
expenditure on a tax-inclusive basis. ${ }^{38}$ In terms of Figure 6 this involves only allocating $\mathrm{C}$ and omitting taxes on intermediate inputs and those on non-household final demand. The modelling of GST reported in Figure 9 (panel $\mathrm{f}$ ) is therefore incomplete in its coverage of the tax - although the majority of this tax is included. The conclusion of this study is that consumption taxes represent $21 \%$ of the gross income for those in the bottom decile but only around $10 \%$ for those at the top: adjusting the data to quintiles, the ratio for the lowest quintiles is only $60 \%$ higher than the top quintiles.

\section{United States}

96. The US literature on consumption tax incidence can be distinguished according to whether these studies are state or federally focused, and whether their approach is based on microsimulation model or some national accounts aggregate allocation framework.

\section{Government studies: Federal}

97. While the Congressional Budget Office (CBO) has developed microsimulation models to analyse the effect of income tax and welfare reforms on households (much like STINMOD and TAXBEN), its application to consumption tax incidence is more limited. This is because the US Federal government only applies consumption taxes in the form of excise and customs duties. CBO in turn only models the incidence of excise duties - not customs duties - assuming that they are passed through to final consumers, while those that affect intermediate goods and are paid by businesses are attributed to households in proportion to their overall consumption. ${ }^{39} \mathrm{CBO}$ assumes that each household spends the same amount on taxed goods as similar households with comparable income in the Consumer Expenditure Survey' (CBO, 2006). ${ }^{40}$ The income measure used to rank households is their comprehensive pre-tax household income adjusted for household size based on the square root of the household's size. Households are ranked by their adjusted income and grouped into quintiles which contain equal numbers of persons (CBO, 2006, p. 4). CBO estimates of the distributional impact of Federal Excise Duties indicate that households in the lowest quintile pay for Federal Excise Taxes around 2\% of their comprehensive income, four times as much as those in the top quintile; since 1980 this incidence has risen for those at the top of the income distribution and declined for those at the bottom (Figure 10).

98. Other US Federal Government agencies that have prepared estimates of the distributional impact of consumption taxes include the Office of Tax Analysis in the US Treasury, ${ }^{41}$ the Joint Committee on Taxation $^{42}$ and the Joint Economic Committee, ${ }^{43}$ but it appears that the CBO is the primary government agency currently preparing consumption tax incidence estimates.

38. If $\mathrm{t}$ is the VAT rate (or tax exclusive rate) then the tax inclusive rate to apply to nominal expenditure reported in a household survey is $t /(1+t)$.

39. Effective tax rates equal the amount of tax liability divided by income. See Congressional Budget Office, Effective Federal Tax Rates, 1979-1997 (October 2001) and Effective Federal Tax Rates, 1997 to 2000 (August 2003), as well as Web-only updates that extend the period of analysis through 2003.

40. Source page 3 of $\mathrm{CBO}(2006)<$ http://www.cbo.gov/ftpdocs/77xx/doc7718/EffectiveTaxRates.pdf $>$

41. See $<\mathrm{http}: / /$ www.treas.gov/offices/tax-policy/library/ota85.pdf $>$

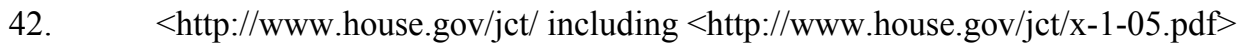

43. $\quad<\mathrm{http}: / / \mathrm{www} \cdot h o u s e . g o v / j e c / t a x a t i o n / t a x a t i o n . h t m l>$ 


\section{Government studies: State}

99. Most US States maintain their own tax impact models. As in Canada, it is also common to find state consumption taxes accompanied by some assistance to low income households such as sales tax credits. What is noteworthy about US State taxation is that a large proportion of the revenue collected by state governments is from taxes on consumption. As a consequence, any major review of the distributional impact of State taxes on households must inevitably model the incidence of consumption taxes. The methodologies adopted in some of these studies have begun to model more rigorously the distributional impact of consumption taxes, i.e. as fully set out in Figures 5 and $6 .{ }^{44}$ However, these State based studies only focus on incidence of their own taxes, while taking only limited account of the important interjurisdictional tax shifting arguments and Federal taxes. ${ }^{45}$

\section{Non-Government Studies}

100. Most studies on the incidence of all Federal and State consumption taxes in the United States are undertaken by non-Government agencies, in particular by the Tax Policy Center (a Joint Venture of the Urban Institute and Brookings Institution), ${ }^{46}$ the Institute on Taxation and Economic Policy, ${ }^{47}$ the Center on Budget and Policy Priorities ${ }^{48}$ and the Tax Foundation. ${ }^{49}$ This section focuses on recent reports by the Tax Foundation and the Institute on Taxation and Economic Policy (ITEP) as these studies follow very different methodological approaches to the estimation of consumption tax incidence.

101. A detailed description of the ITEP model is accessible from the ITEP website. ${ }^{50}$ Essentially, ITEP relies on a microsimulation model which is used to calculate the revenue yield and distributional impact of federal, state and local taxes and tax reforms. The model works with a large stratified unit record sample of tax returns (IRS Individual Public Use Tax File) which is supplemented with other data from the US Population Survey, Consumer Expenditure Survey, and U.S. Census data. This microsimulation model is conceptually similar to the CBO and OTA models but has the advantage of estimating state-by-state tax incidence. The model includes a number of modules:

- The personal income tax module is used to analyse the implications for revenue levels and incidence of reforms to federal and state personal income taxes;

44. See the Oregon Tax Incidence Model (OTIM) $<$ http://www.agribusinessmgmt.wsu.edu/Holland_model/docs/OregonTaxIncidenceModel.pdf $>$, Washington State $<$ http://dor.wa.gov/Content/AboutUs/StatisticsAndReports/WAtaxstudy/Final_Report.htm>, Maserov(2002)<http://www.cbpp.org/1-15-02sfp2.pdf>,

45. US states with multi-tax household impact models include Colorado, Maine, Minnesota, Missouri, Nebraska, Oregon, Texas, and Washington. Those states developing multi-tax economic incidence models include Alabama and New Hampshire and those states with multi-tax initial tax impact-type models include Utah. States with personal income tax microsimulation models include Arizona, Massachusetts, Ohio California, Michigan, Pennsylvania, Delaware, Mississippi, Rhode Island, Illinois, Montana, Vermont, Iowa, New Jersey, Virginia, Kansas, New Mexico, Wisconsin, Kentucky, New York, Maryland, and North Carolina. All other states lack significant tax incidence analysis capacity. See Mazerov (2002), Figure 4, p $45<$ http://www.cbpp.org/1-15-02sfp2.htm>

46. $\quad$ See $<$ http://www.taxpolicycenter.org/home/ $>$

47. $\quad$ See $<$ http://www.ctj.org/itep/>

48. $\quad$ See $<$ http://www.cbpp.org/pubs/fedtax.htm>

49. See $<$ http://www.taxfoundation.org/>

50. See $<$ http://ctj.org/itep/itepmodel.htm>, $<$ http://ctj.org/itep/modelmenu.htm $>$ and in particular $<$ http://ctj.org/itep/model.htm>, 
- The consumption tax module is based on input-output data and used to estimate the effective consumption tax rates applied to more than 250 items; ${ }^{51}$ and

- The modules for property tax and corporate incomes.

\section{Figure 10. The incidence of consumption taxes in the United States}

a. CBO: Effective Federal Excise Tax Rates for All Households, by Comprehensive Household Income Quintile

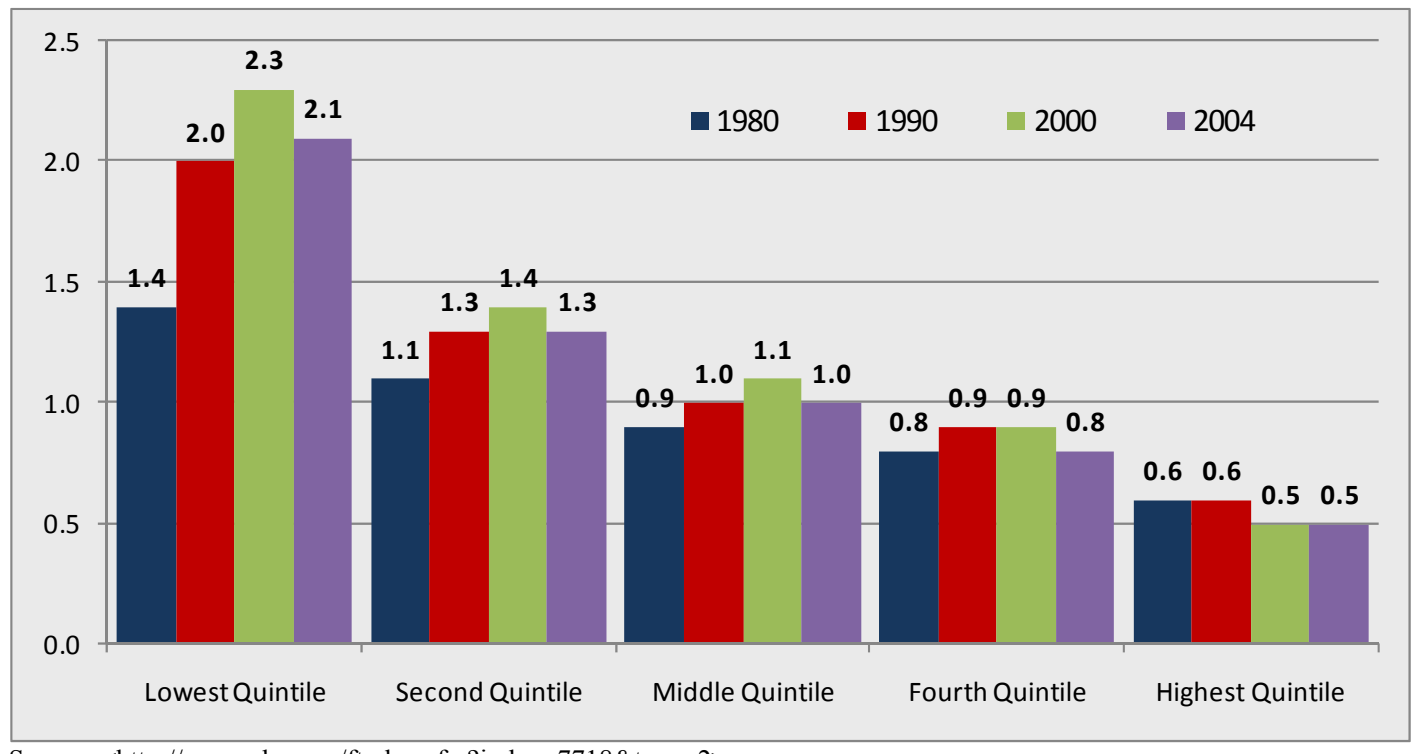

Source: $<$ http://www.cbo.gov/ftpdoc.cfm?index=7718\&type $=2>$

b. ITEP: Average Effective Tax Rates by Type of StateTax on Non-elderly taxpayers: 2002

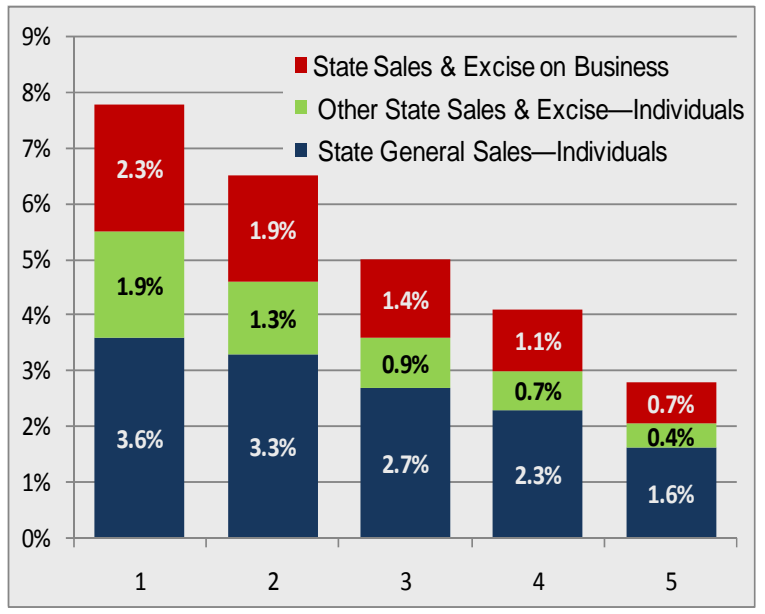

Source: McIntyre, Denk, Francis, Gardner, Gomaa, Hsu, and Sims (2003) p. $118<$ http://www.itepnet.org/whopays.htm> c. Tax Foundation: Estimates of Average Effective Tax Rates by Type of Tax, Calendar Year 2004

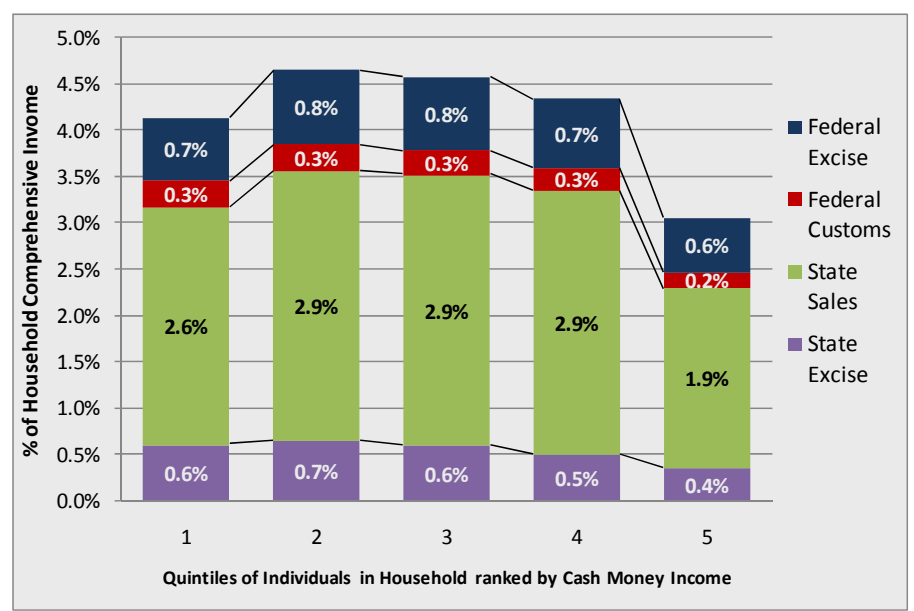

Source: Table 16 in Chamberlain and Prante(2007),

$<$ http://www.taxfoundation.org/publications/show/2282.html $>$

102. In terms of tax shifting, the ITEP model assumes that the burden of consumption taxes paid by individuals falls directly on them and that consumption taxes on visitors are borne by the visitors. In the case of sales and excise taxes on intermediate inputs, ${ }^{52}$ those on domestic items are assumed to be borne by

51. $\quad$ See $<$ http://ctj.org/itep/model.htm $>$

52. $\quad$ See $<$ http://ctj.org/itep/model.htm $>$ 
the residents of each state (except for amounts paid by visitors) according to their share of total consumption, while those on national items are assigned to national consumption with an adjustment to reflect the proportion (about 15\%) retained in each state. Based on these assumptions, state sales and excise taxes in the ITEP model are estimated to weigh for around $8 \%$ of the income of (non-elderly) taxpayers in the first quintile, as compared to around $3 \%$ for those in top quintile.

103. Estimates by the Tax Foundation rely on the use of income and expenditure data to allocate national aggregates of income and taxes. The approach, which is similar to that in Warren $(1979,1997)$, is based on household survey data as the foundation on which to distribute national accounts income and tax data. This approach is "closed", as it seeks to assign all national accounts aggregates to particular household groups. Essentially, the household unit record (survey) data on income and expenditure is used to allocate national accounts aggregates to households, rather than as the basis for modelling how taxes impact on the surveyed household. The strength of this approach is its all-inclusiveness - its weakness is that the results are only as good as the data series used to allocate the national aggregates. Any evidence of income or expenditure underreporting, population underreporting or errors in sampling, will potentially exacerbate problems with any results obtained.

104. An added problem with the Tax Foundation approach is how to interpret the results obtained. This approach assigns national aggregates to surveyed households on the basis of their share of different income and expenditure items in the survey. These surveys measure only observable variables such as cash income and actual nominal expenditure, which is a narrower measure of income and expenditure than in the national accounts (which also includes a number of substantial imputed items). Not only will the use of some broad income measures increase household income over some narrower money income measures, but any under or over reporting in the survey or allocation of imputed sources will potentially change the ranking of households by broad income vis a vis money income. An additional question is what interpretation to give to the concept of broad income - since it is not an income directly relevant to individual households. Conceptual problems also arise when allocating aggregate consumption taxes. When underreporting on a particular consumption item differs across income groups, allocating a national accounts aggregate based on the distribution of this expenditure between households could yield skewed results. This problem does not arise when using a microsimulation model, as in this case a tax rate calculated from the national accounts data (or using official tax rates) is applied directly to the household data. However, a problem which arises here is that we may not ultimately be allocating all of the tax collected from the expenditure on a particular item (Warren, 1997; Vermaeten et al., 1995).

105. In the Tax Foundation study, households are ranked by cash money income and grouped into quintiles containing "roughly equal numbers of people, and thus unequal numbers of households" (p. 16); the tax incidence estimates are based on this broader income concept because money income is "not an appropriate measure of households' total economic income" (p. 17). ${ }^{53}$ However, the income measure estimated for each household group is adjusted to account for transfers between households resulting in a

53. The approach taken and its rationale is that (p. 17): "When dividing taxes or spending by household income in order to express households' 'ability to pay,' it is important to attribute all taxes and all income to households. Because all taxes in the economy are assumed to be borne by households, it becomes important to also attribute to households all the income in the economy that is available to pay those taxes. Expressing tax burdens as a percentage of narrow income concepts like cash money income does not provide a sound measure of a household's true ability to pay taxes, and thus may overstate true effective tax rates by a large amount. For this reason, tax distribution studies have traditionally used broader definitions of income when comparing taxes to income. .. In this study, we also use a broad income concept whenever taxes or spending are expressed as a percentage of income. This income concept consists of each household's market income from productive activity plus the value of all net government transfer payments received. In the aggregate, this broad income concept is equal to the nation's Net National Product (NNP) as defined by the National Income and Product Accounts (NIPA)". 
measure of 'Household Comprehensive Income' equal to household market income plus the value of government transfers received by a household less the cost of government transfers to other households. The argument is that to do otherwise would result "in double-counting of government transfers on an economy-wide basis" (p. 17) ${ }^{54}$ This approach to defining income is driven by a focus on economy-wide (national accounts) effects and has implications when interpreting estimates. In terms of the allocation of consumption taxes, the assumptions made varied between types of taxes. For example, the Federal Excise Tax on Gasoline was assumed to fall $50 \%$ on consumers of gasoline and $50 \%$ on the same allocation as the corporate income tax. With Federal and State Excise on Diesel Fuel, 100\% was allocated on the same basis as the corporate income tax. Federal and State excise on tobacco and alcohol was assumed to fall on consumers of those products, Federal Customs Duties to fall on consumers in proportion to their total consumption expenditures, and General State Sales Taxes to fall on consumers in proportion to their expenditures on taxable goods and services. ${ }^{55}$

106. The summary results from this Tax Foundation study led to decidedly different distributional outcomes to other studies as shown in Figure 10 (panel c). Here, consumption taxes impact more on middle income groups than on either the lower or upper income groups. These results arise directly from the methodological approach adopted in this study.

\subsection{Comparative studies}

107. This section reviews studies providing a comparative perspective on the incidence of consumption taxes, using household survey data from a number of different countries. Special attention will be given to studies based on the Luxembourg Income Study and EUROMOD.

\section{LIS based multi-country studies}

108. The Luxembourg Income Study (LIS) project, which started in 1983, covers 30 countries and currently provides survey data on income, demographic, labour market and expenditure information for households, persons and children. ${ }^{56}$ The ultimate objective of LIS is to construct a harmonised database that can be used to facilitate international comparative studies.

109. Garfinkel, Rainwater and Smeeding (2006) use LIS data for 12 countries to "extend previous analyses of the distributional effects of welfare state programs in rich countries by taking into account both in-kind benefits and all the taxes required to finance these benefits". The approach taken is to distinguish the LIS definition of disposable income from a new concept called 'full income' which adds to disposable income the value of health and education benefits and subtracts the value-added taxes (VAT), sales, excise, corporate taxes, and real property taxes required to finance the cash and near-cash expenditure on selected health and education benefits. ${ }^{57}$ This approach highlights the redistributive qualities of consumption, corporate and property taxes when they are used to exactly fund government expenditure on selected health and education benefits.

110. To allocate the taxes on consumption, corporations and property, Garfinkel, Rainwater and Smeeding (2006, p. 902) assumes that the incidence of the corporate tax and of the goods and services tax

54. See Chamberlain and Prante (2007), Table 4 and footnote 17 on p17.

55. For a detailed outline of the assumptions, see Chamberlain and Prante (2007), Table 53 and 54.

56. For a full description of LIS, see $<\mathrm{http}: / /$ www.lisproject.org/introduction.htm $>$

57. For a fuller description of the approach, see Garfinkel, Rainwater and Smeeding (2006) - available at $<$ http://www.columbia.edu/cu/childpolicy/whatsnew/A $\% 20$ Reexamination $\% 20$ of $\% 20$ welfare $\% 20$ states $\% 2$ 0and\%20inequality\%20Garfinkel\%20Rainwater\%20Smeeding\%202006.pdf> 
falls on the consumer, and thus distributed these taxes according to overall consumption; and that the incidence of the property tax falls on housing consumption. Corporate, goods and services, and property taxes are assigned according to LIS-calculated ratios of overall expenditure (including housing expenditure) to income by disposable income decile. Decile-specific consumption to income ratios are taken from micro data surveys for four nations (Canada, France, the United Kingdom, and the United States) and an average of the four is applied to other nations. In these four countries, consumption exceeds income in the bottom quintile, which means that consumption and value-added taxes are regressive not just at the top, but also at the bottom of the income distribution.

111. While this approach is a rough approximation, it provides some insight into the redistributive qualities of consumption taxation. Table 4 outlines the key findings from the study. ${ }^{58}$ The distribution of full income (panel B) is dramatically different from that of disposable income (panel A), especially at the bottom of the distribution. However, the results do not allow distinguishing the impact of consumption taxes from that of other elements which comprise full income such as in-kind services. The authors also find that "a large part of what the welfare state does is to transfer resources across the life cycle, and confining the analysis to households at the beginning and households at the end of the life cycle is a crude method of abstracting from life cycle effects". (p. 906). A limitation of this approach, acknowledged by the authors, is the focus on only one measure of inequality, and the use of a crude estimate of consumption to income.

Table 4. The impact of including in-kind transfers funded by consumption taxes on the distribution of household income: evidence from LIS

Inter-decile ratios, as a percentage of median equivalent income in each panel

\begin{tabular}{|c|c|c|c|c|c|c|}
\hline & \multicolumn{3}{|c|}{ A. Disposable personal income } & \multicolumn{3}{|c|}{ B. Actual Full income } \\
\hline & $\begin{array}{r}\mathrm{P} 10 / \mathrm{P} 50 \\
\text { (Low } \\
\text { Income) }\end{array}$ & $\begin{array}{r}\text { P90/P50 } \\
\text { (High } \\
\text { Income) }\end{array}$ & $\begin{array}{r}\text { P90/P10 } \\
\text { (Decile } \\
\text { ratio) }\end{array}$ & $\begin{array}{r}\mathrm{P} 10 / \mathrm{P} 50 \\
\text { (Low } \\
\text { Income) }\end{array}$ & $\begin{array}{r}\text { P90/P50 } \\
\text { (High } \\
\text { Income) }\end{array}$ & $\begin{array}{r}\text { P90/P10 } \\
\text { (Decile } \\
\text { ratio) }\end{array}$ \\
\hline Australia 1994 & 45 & 192 & 422 & 52 & 172 & 331 \\
\hline Canada 1997 & 47 & 186 & 399 & 52 & 173 & 334 \\
\hline United Kingdom 1999 & 47 & 214 & 454 & 55 & 190 & 349 \\
\hline United States 2000 & 39 & 210 & 543 & 53 & 193 & 365 \\
\hline Belgium 1997 & 53 & 170 & 319 & 54 & 172 & 317 \\
\hline France 1994 & 56 & 190 & 339 & 57 & 172 & 300 \\
\hline Germany 2000 & 56 & 177 & 316 & 57 & 166 & 293 \\
\hline Netherlands 1999 & 55 & 169 & 307 & 57 & 161 & 280 \\
\hline Finland 2000 & 57 & 164 & 290 & 54 & 168 & 306 \\
\hline Sweden 2000 & 57 & 168 & 295 & 58 & 156 & 269 \\
\hline Average & 51 & 184 & 368 & 55 & 172 & 314 \\
\hline
\end{tabular}

Source: Garfinkel, Rainwater and Smeeding (2006, p. 908).

\section{EUROMOD studies}

112. While the LIS databases are useful for 'what is' type research, it is not that helpful for 'what could be' - i.e. to assess the impact of reform possibilities. This is where the development of EUROMOD (a multi-country Europe-wide tax-benefit model involving researchers from 15 European Union member

58. The authors also "adjust household incomes (both disposable and full incomes) to reflect differences in household size by dividing income by the square root of household size. This equivalence scale allows for economies of scale, but does not unduly bias measures toward larger units (with children) or smaller units (with elders)" (p. 903). See the paper for more discussion on this issue, particularly in regard to the allocation of in-kind benefits which do not exhibit economies of scale (p. 903). 
states) has its real contribution. ${ }^{59}$ O'Donoghue, Baldini and Mantovani (2004) extend EUROMOD to include consumption taxation. ${ }^{60}$ Because expenditure data is not available for all countries in the EUROMOD data set, a multi-step process is used to estimate the various expenditure types by the households reported in the EUROMOD databases. ${ }^{61}$

113. Table 5 details the estimated VAT and Excise revenue by the amended EUROMOD as against the official estimates of revenue collected. Some differences are evident - even when no account is taken of the impact of these taxes on intermediate inputs. ${ }^{62}$ This would imply that the modelling approach adopted is still in need of refinement both to reduce this difference and to cover a greater proportion of VAT and Excise in the respective countries.

Table 5. Total revenue from consumption taxes in 12 EU countries, 1998)

\begin{tabular}{|c|c|c|c|c|c|c|c|c|c|}
\hline & \multicolumn{3}{|c|}{ VAT } & \multicolumn{3}{|c|}{ Excise Duties } & \multicolumn{3}{|c|}{ Total } \\
\hline & EUROMOD & Official Stats & $\%$ & EUROMOD & Official Stats & $\%$ & EUROMOD & Official Stats & $\%$ \\
\hline Belgium & 307885 & 586051 & 52.5 & 106903 & 23482 & 455.30 & 414787 & 949017 & 43.7 \\
\hline Finland & 33204 & 38609 & 86.0 & 14345 & 16032 & 89.50 & 47549 & 65006 & 73.1 \\
\hline France & 636757 & 807700 & 78.8 & 139298 & 155400 & 89.60 & 776056 & 1112500 & 69.8 \\
\hline Greece & 2286248 & 2723321 & 84.0 & 1050477 & 1856100 & 56.60 & 3336725 & 5248393 & 63.6 \\
\hline Ireland & 2425 & 4270 & 56.8 & 1947 & 2822 & 69.00 & 4372 & 7092 & 61.7 \\
\hline Italy & 102661 & 131793 & 77.9 & 43458 & 50914 & 85.40 & 146119 & 257772 & 56.7 \\
\hline Luxembourg & 22270 & 31529 & 70.6 & 5020 & 23940 & 21.00 & 27291 & 61700 & 44.2 \\
\hline Netherlands & 32229 & 53710 & 60.0 & 7935 & 15795 & 50.20 & 40164 & 93512 & 43.0 \\
\hline Portugal & 872443 & 1132610 & 77.0 & 231429 & 769320 & 30.10 & 1103872 & 2137000 & 51.7 \\
\hline Spain & 3403232 & 4319425 & 78.8 & 747613 & 2376950 & 31.50 & 4150844 & 6949762 & 59.7 \\
\hline Sweden & 110744 & 162600 & 68.1 & 27063 & 82236 & 32.90 & 137806 & 244800 & 56.3 \\
\hline United Kingdom & 42368 & 51950 & 81.6 & 19133 & 36720 & 52.10 & 61502 & 92976 & 66.1 \\
\hline
\end{tabular}

Source: O'Donoghue, Baldini and Mantovani (2004), Table 4.

59. EUROMOD is microsimulation model that provides estimates of the distributional impact of current and alternative personal tax and transfer policies. The model can therefore be used to assess policies in one or a number of countries as well as the consequences of one country's policies on other countries and how these may work for or against EU wide objectives. EUROMOD has been supported through a number of European Commission-funded projects including expanding its coverage to enable EUROMOD to incorporate the $10 \mathrm{New}$ Member States of 2004. See <http://www.iser.essex.ac.uk/msu/emod/>

60. As EUROMOD does not include the expenditure data required for the simulation of consumption taxes, the solution adopted was to develop a "modelling system within the EUROMOD model to simulate expenditure by consumption type and then simulate a range of consumption taxes (VAT, excise duties and Ad Valorem Taxes). The imputation of expenditure and budget shares is done through a series of regressions on the National Household Budget Surveys" (p. 1).

61. This multi-step process involves firstly estimating the relationship between income, total expenditure and various demographic variables; and secondly, since consumption taxes are levied at different rates on a range of goods and services, estimating the relationship between total expenditure and expenditure disaggregated into sub-groups, thus enabling the estimation of household budget shares for specific types of expenditure. The functional relationships estimated are then applied to the EUROMOD income data to estimate a range of expenditure types by individual households to which official nominal VAT and Excise rates can be applied. See O’Donoghue, Baldini and Mantovani (2004) for a detailed description of the methodology adopted $<\mathrm{http}$ ://www.iser.essex.ac.uk/msu/emod/workingpapers/em701.pdf >

62. O'Donoghue, Baldini and Mantovani (2004) offer a number of possible reasons for apparent underestimation of estimated VAT relative to official total revenue including "Firstly not all indirect taxes are passed on to final consumers because for example some sectors do not pay VAT and so cannot claim VAT refunds. Also the household sector does not account for all final consumption on which VAT is incident. For example government activities and charities will pay VAT, but will not be included in the simulated VAT totals here. An incidence analysis employing an input-output table as per Scutella (1997) may help to identify the true incidence of indirect taxes. Excise duties paid on intermediate inputs will also not be modelled in this type of analysis." (p. 9). This underestimation (and over estimation in some cases) obviously qualifies the distributional impact estimates for VAT and excise in this study and as reported in Table 16. O'Donoghue et al (2004) discussed these issues as they relate to their results in pp. 11-19 of their paper. 
114. Table 6 and Figure 11 outline the distributional impact findings by the study. Consumption taxes represents a share of income of the bottom decile that is, on average, 3 times higher than that for those in the top decile - although it is much lower for Belgium, Netherlands, Luxembourg and Ireland than in the Nordic countries. Excise duties impact 4 times more heavily on the income of the lowest decile relative to the top decile.

115. Table 7 reports the Kakwani progressivity index estimated for the tax-benefit system using EUROMOD. ${ }^{63}$ On this measure, both the VAT and excise duties are regressive in all countries. Portugal has the most regressive consumption taxation, and Belgium the least regressive (for Belgium, this could however reflect the under-reporting of VAT and excises shown in Table 5). In contrast to consumption taxes, most direct taxes and social security contributions are progressive, with income taxes typically being more progressive than employer social security contributions, which in turn are more progressive than the contributions of employees in all countries except Finland, Ireland, Italy and Luxembourg.

116. However, these results need to be treated with some caution. For example, the underreporting of VAT and Excise detailed in Table 5 mean that the results reported in Table 6 underestimate the VAT and Excise burden on individuals, in some cases substantially. While such differences might not impact on the progressivity of the taxes reported in Table 7, they will in terms of the redistributive nature of these taxes.

63. Various other redistributive measures are estimated including the Reynolds-Smolensky measure and the paper should be referenced for these measures. 
DELSA/ELSA/WD/SEM(2008)1

Table 6. Average effective tax rates on VAT and excise duties based on EUROMOD

1998, selected European countries

\begin{tabular}{|c|c|c|c|c|c|c|c|c|c|c|c|c|c|}
\hline \multicolumn{14}{|c|}{ Distribution of VAT Receipts } \\
\hline Decile & Belgium & Finland & France & Greece & Ireland & Italy & $\begin{array}{l}\text { Luxem- } \\
\text { bourg }\end{array}$ & $\begin{array}{l}\text { Nether- } \\
\text { lands }\end{array}$ & Portugal & Spain & Sweden & $\begin{array}{c}\text { United } \\
\text { Kingdom }\end{array}$ & Average \\
\hline 1 & 13.5 & 26.2 & 27.2 & 26.6 & 16.9 & 22.9 & 13.6 & 17.7 & 27.7 & 22.5 & 54.3 & 22.4 & 24.3 \\
\hline 2 & 13.2 & 19.1 & 23.5 & 18.8 & 14.6 & 17.6 & 11.9 & 13.5 & 18.8 & 15.0 & 23.1 & 19.4 & 17.4 \\
\hline 3 & 12.4 & 17.5 & 21.9 & 16.1 & 14.2 & 16.4 & 10.9 & 13.3 & 16.3 & 13.5 & 21.4 & 16.8 & 15.9 \\
\hline 4 & 12.0 & 16.0 & 20.3 & 15.6 & 15.4 & 15.2 & 10.8 & 12.7 & 15.4 & 12.3 & 20.1 & 16.2 & 15.2 \\
\hline 5 & 11.6 & 15.1 & 18.8 & 14.4 & 15.2 & 14.2 & 10.0 & 12.6 & 14.2 & 11.5 & 19.0 & 14.6 & 14.3 \\
\hline 6 & 11.2 & 14.2 & 17.7 & 13.7 & 14.7 & 12.7 & 9.5 & 12.3 & 13.2 & 11.0 & 18.0 & 15.0 & 13.6 \\
\hline 7 & 11.1 & 13.1 & 17.4 & 12.8 & 13.2 & 12.4 & 9.3 & 11.5 & 11.2 & 10.2 & 17.1 & 13.8 & 12.8 \\
\hline 8 & 10.7 & 11.8 & 16.1 & 12.3 & 12.4 & 11.3 & 8.9 & 11.0 & 10.3 & 9.3 & 16.0 & 13.1 & 11.9 \\
\hline 9 & 10.5 & 10.6 & 14.6 & 11.5 & 11.7 & 10.6 & 8.3 & 10.1 & 9.1 & 8.8 & 15.0 & 12.4 & 11.1 \\
\hline 10 & 9.9 & 7.2 & 11.3 & 9.4 & 8.2 & 7.5 & 6.9 & 8.2 & 6.3 & 7.2 & 9.6 & 9.5 & 8.4 \\
\hline Total & 11.1 & 13.2 & 16.7 & 12.8 & 12.3 & 11.7 & 9.1 & 11.2 & 11.1 & 10.2 & 16.2 & 13.3 & 12.4 \\
\hline Ratio D10/D1 & 0.73 & 0.27 & 0.42 & 0.35 & 0.49 & 0.33 & 0.51 & 0.46 & 0.23 & 0.32 & 0.18 & 0.42 & 0.35 \\
\hline Q5/Q1 & 0.76 & 0.39 & 0.51 & 0.46 & 0.63 & 0.45 & 0.60 & 0.59 & 0.33 & 0.43 & 0.32 & 0.52 & 0.47 \\
\hline D1/Ave & 0.82 & 0.50 & 0.61 & 0.48 & 0.73 & 0.51 & 0.67 & 0.63 & 0.40 & 0.45 & 0.30 & 0.59 & 0.51 \\
\hline \multicolumn{14}{|c|}{ Distribution of Excise Duties } \\
\hline & Belgium & Finland & France & Greece & Ireland & Italy & $\begin{array}{l}\text { Luxem- } \\
\text { bourg }\end{array}$ & $\begin{array}{l}\text { Nether- } \\
\text { lands }\end{array}$ & Portugal & Spain & Sweden & $\begin{array}{l}\text { United } \\
\text { Kingdom }\end{array}$ & Average \\
\hline 1 & 5.7 & 10.5 & 9.1 & 11.8 & 16.4 & 11.9 & 4.0 & 4.8 & 6.0 & 6.4 & 19.1 & 14.7 & $\overline{10.0}$ \\
\hline 2 & 5.7 & 7.4 & 6.6 & 7.2 & 12.6 & 8.1 & 3.2 & 3.3 & 4.4 & 3.2 & 7.1 & 13.0 & 6.8 \\
\hline 3 & 5.1 & 7.0 & 5.7 & 5.9 & 12.4 & 7.3 & 2.9 & 3.3 & 4.4 & 3.0 & 6.4 & 10.7 & 6.2 \\
\hline 4 & 4.8 & 6.3 & 5.3 & 5.6 & 13.0 & 6.9 & 2.7 & 3.2 & 4.4 & 2.7 & 5.6 & 9.5 & 5.8 \\
\hline 5 & 4.5 & 6.2 & 4.7 & 5.0 & 12.5 & 6.4 & 2.3 & 3.0 & 4.0 & 2.7 & 5.0 & 8.0 & 5.4 \\
\hline 6 & 4.2 & 5.9 & 4.1 & 4.6 & 11.8 & 5.6 & 2.3 & 3.1 & 3.8 & 2.5 & 4.8 & 7.6 & 5.0 \\
\hline 7 & 4.0 & 5.5 & 3.8 & 4.1 & 10.5 & 5.4 & 2.1 & 2.8 & 3.2 & 2.3 & 4.3 & 6.6 & 4.6 \\
\hline 8 & 3.8 & 4.9 & 3.1 & 3.6 & 9.8 & 4.8 & 1.9 & 2.7 & 2.9 & 2.1 & 3.6 & 5.9 & 4.1 \\
\hline 9 & 3.6 & 4.4 & 2.4 & 3.1 & 9.0 & 4.4 & 1.6 & 2.4 & 2.4 & 1.8 & 3.0 & 5.1 & 3.6 \\
\hline 10 & 2.9 & 2.8 & 1.5 & 2.1 & 5.9 & 2.6 & 1.2 & 1.9 & 1.5 & 1.3 & 1.5 & 3.2 & 2.4 \\
\hline Total & 4.0 & 5.4 & 3.6 & 4.0 & 9.8 & 5.0 & 2.1 & 2.7 & 2.9 & 2.2 & 4.0 & 6.5 & 4.4 \\
\hline Ratio D10/D1 & 0.51 & 0.27 & 0.16 & 0.18 & 0.36 & 0.22 & 0.30 & 0.40 & 0.25 & 0.20 & 0.08 & 0.22 & 0.24 \\
\hline Q5/Q1 & 0.57 & 0.40 & 0.25 & 0.27 & 0.51 & 0.35 & 0.39 & 0.53 & 0.38 & 0.32 & 0.17 & 0.30 & 0.35 \\
\hline D1/Ave & 0.70 & 0.51 & 0.40 & 0.34 & 0.60 & 0.42 & 0.53 & 0.56 & 0.48 & 0.34 & 0.21 & 0.44 & 0.43 \\
\hline \multicolumn{14}{|c|}{ Distribution of both VAT and Excise Duties } \\
\hline & Belgium & Finland & France & Greece & Ireland & Italy & $\begin{array}{l}\text { Luxem- } \\
\text { bourg }\end{array}$ & $\begin{array}{l}\text { Nether- } \\
\text { lands }\end{array}$ & Portugal & Spain & Sweden & $\begin{array}{c}\text { United } \\
\text { Kingdom }\end{array}$ & Average \\
\hline 1 & 19.2 & 36.7 & 36.3 & 38.4 & 33.3 & 34.8 & 17.6 & 22.5 & 33.7 & 28.9 & 73.4 & 37.1 & $\overline{34.3}$ \\
\hline 2 & 18.9 & 26.5 & 30.1 & 26.0 & 27.2 & 25.7 & 15.1 & 16.8 & 23.2 & 18.2 & 30.2 & 32.4 & 24.2 \\
\hline 3 & 17.5 & 24.5 & 27.6 & 22.0 & 26.6 & 23.7 & 13.8 & 16.6 & 20.7 & 16.5 & 27.8 & 27.5 & 22.1 \\
\hline 4 & 16.8 & 22.3 & 25.6 & 21.2 & 28.4 & 22.1 & 13.5 & 15.9 & 19.8 & 15.0 & 25.7 & 25.7 & 21.0 \\
\hline 5 & 16.1 & 21.3 & 23.5 & 19.4 & 27.7 & 20.6 & 12.3 & 15.6 & 18.2 & 14.2 & 24.0 & 22.6 & 19.6 \\
\hline 6 & 15.4 & 20.1 & 21.8 & 18.3 & 26.5 & 18.3 & 11.8 & 15.4 & 17.0 & 13.5 & 22.8 & 22.6 & 18.6 \\
\hline 7 & 15.1 & 18.6 & 21.2 & 16.9 & 23.7 & 17.8 & 11.4 & 14.3 & 14.4 & 12.5 & 21.4 & 20.4 & 17.3 \\
\hline 8 & 14.5 & 16.7 & 19.2 & 15.9 & 22.2 & 16.1 & 10.8 & 13.7 & 13.2 & 11.4 & 19.6 & 19.0 & 16.0 \\
\hline 9 & 14.1 & 15.0 & 17.0 & 14.6 & 20.7 & 15.0 & 9.9 & 12.5 & 11.5 & 10.6 & 18.0 & 17.5 & 14.7 \\
\hline 10 & 12.8 & 10.0 & 12.8 & 11.5 & 14.1 & 10.1 & 8.1 & 10.1 & 7.8 & 8.5 & 11.1 & 12.7 & 10.8 \\
\hline Total & 15.1 & 18.6 & 20.3 & 16.8 & 22.1 & 16.7 & 11.2 & 13.9 & 14.0 & 12.4 & 20.2 & 19.8 & 16.8 \\
\hline Ratio D10/D1 & 0.67 & 0.27 & 0.35 & 0.30 & 0.42 & 0.29 & 0.46 & 0.45 & 0.23 & 0.29 & 0.15 & 0.34 & 0.31 \\
\hline Q5/Q1 & 0.71 & 0.40 & 0.45 & 0.41 & 0.58 & 0.41 & 0.55 & 0.58 & 0.34 & 0.41 & 0.28 & 0.43 & 0.44 \\
\hline D1/Ave & 0.79 & 0.51 & 0.56 & 0.44 & 0.66 & 0.48 & 0.64 & 0.62 & 0.42 & 0.43 & 0.28 & 0.53 & 0.49 \\
\hline
\end{tabular}

Notes: 1. Deciles based upon Equivalised Household Disposable Income.

2. Income used for ranking purposes has been equivalised using the equivalence scale 1/0.5/0.3, where children are aged 17 or under.

3. Tax Rates as a percentage of Expenditure or Disposable Income are unequivalised.

4. Ratio 1/10 - Ratio of VAT as percentage of disposable income in decile 1 to rate in decile 10.

5. Ratio 1/Ave - Ratio of VAT as percentage of disposable income in decile 1 to rate on average.

Source: O'Donoghue, Baldini and Mantovani (2004) Tables 6 and 7. 
Figure 11. Measures of the incidence of consumption taxes in selected European countries based on EUROMOD
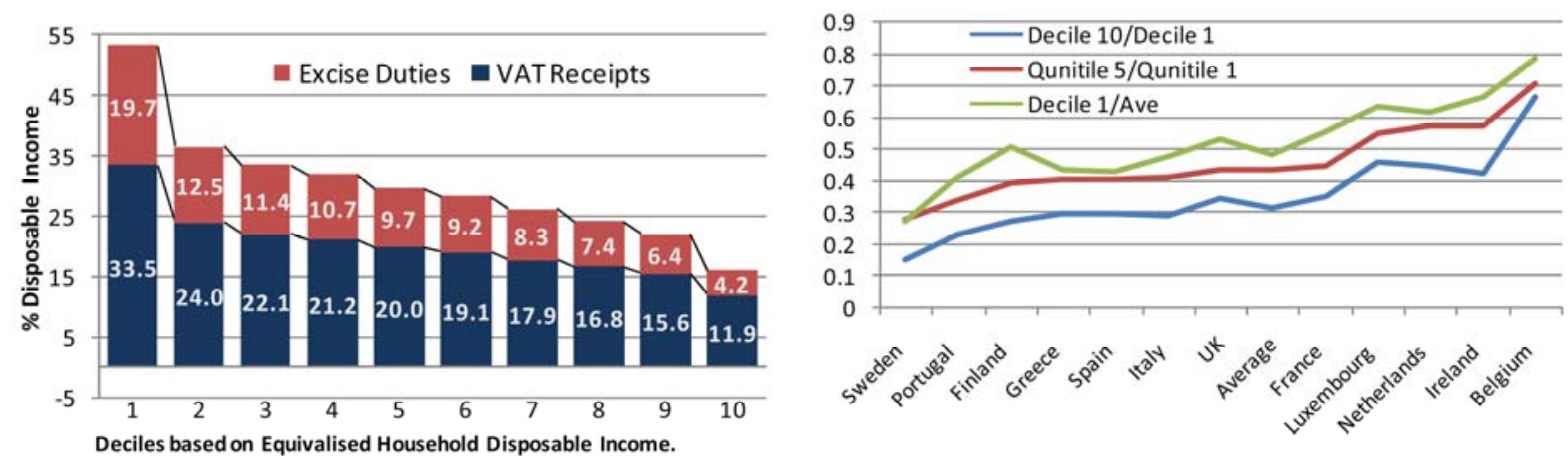

Source: O'Donoghue, Baldini and Mantovani (2004) Tables 6 and 7.

Table 7. Progressivity of indirect tax compared to other instruments based on EUROMOD

Progressivity as measured by the Kakwani Index

\begin{tabular}{|c|c|c|c|c|c|c|c|c|c|c|c|c|c|c|c|}
\hline & Austria & Belgium & Denmark & Finland & France & Germany & Greece & Ireland & Italy & $\begin{array}{c}\begin{array}{c}\text { Luxem- } \\
\text { bourg }\end{array} \\
\end{array}$ & $\begin{array}{l}\begin{array}{l}\text { Nether- } \\
\text { lands }\end{array} \\
\end{array}$ & Portugal & Spain & Sweden & $\begin{array}{c}\text { United } \\
\text { Kingdom }\end{array}$ \\
\hline VAT & & -1.9 & & -19.4 & -15.4 & & -12.5 & -13.7 & -16.1 & -9.4 & -9.8 & -23.1 & -14.5 & -9.0 & -12.0 \\
\hline Excise Duty & & -8.5 & & -21.9 & -31.5 & & -23.6 & -17.5 & -21.8 & -18.6 & -13.0 & -25.2 & -18.4 & -21.5 & -24.6 \\
\hline Indirect Taxation & & -3.1 & & -17.4 & -16.6 & & -13.6 & -12.3 & -15.9 & -10.4 & -9.5 & -21.6 & -14.2 & -10.6 & -14.0 \\
\hline ERSIC & 11.2 & 24.9 & 14.1 & 19.9 & 12.2 & 11.6 & 7.2 & 17.6 & 8.8 & 5.4 & 5.2 & 11.7 & 14.0 & 20.0 & 20.5 \\
\hline EESIC & 10.3 & 21.7 & 17.8 & 12.0 & 8.2 & 11.6 & -0.3 & 19.5 & 7.9 & 7.6 & 4.0 & 3.0 & -2.3 & 7.9 & 15.7 \\
\hline Income Tax & 27.1 & 25.4 & 12.2 & 14.0 & 30.8 & 32.8 & 27.5 & 26.3 & 7.1 & 35.5 & 30.5 & 27.1 & 29.2 & 10.1 & 23.4 \\
\hline Direct Taxes & 13.1 & 19.0 & 11.3 & 12.4 & 11.8 & 18.0 & 12.4 & 22.7 & 6.5 & 17.2 & 10.2 & 12.9 & 16.2 & 11.3 & 19.6 \\
\hline All tax & & 14.3 & & 6.9 & 5.1 & & 3.5 & 6.3 & 2.4 & 11.3 & 7.0 & 6.1 & 8.6 & 7.3 & 7.4 \\
\hline Family Benefits & -60.5 & -43.8 & -38.8 & -37.9 & -72.3 & -56.5 & -25.3 & -50.3 & -96.8 & -57.8 & -45.9 & -50.8 & -90.2 & -55.5 & -56.7 \\
\hline Housing Benefits & -58.8 & & -83.2 & -94.7 & -99.5 & -95.6 & -6.1 & -127.5 & & -109.4 & -98.4 & -87.4 & -45.8 & & -105.9 \\
\hline Other Benefits/Pensions & -129.4 & -148.7 & -121.8 & -140.7 & -150.3 & -111.7 & -126.2 & -126.9 & -110.1 & -125.9 & -112.7 & -114.4 & -123.2 & -151.7 & -95.2 \\
\hline Unemployment Benefits & -83.4 & -101.2 & -110.8 & -101.1 & -103.7 & -90.1 & -74.2 & -87.2 & -111.0 & -98.8 & -113.6 & -97.2 & -73.6 & -125.6 & -93.0 \\
\hline Social Assistance Benefits & -95.9 & -119.3 & -127.3 & -37.3 & -105.5 & -109.6 & -118.0 & -129.6 & -101.3 & -126.0 & -160.8 & -178.3 & -93.5 & -125.1 & -119.0 \\
\hline Benefits & -120.8 & -131.9 & -120.8 & -123.8 & -140.3 & -104.9 & -123.6 & -124.0 & -113.2 & -118.2 & -114.7 & -111.1 & -121.5 & -146.1 & -121.4 \\
\hline Tax-Benefit System & -289.6 & -131.4 & -124.6 & -138.7 & -97.0 & -254.5 & -171.9 & -112.0 & -108.7 & -273.6 & -66.0 & -99.0 & -346.1 & -106.4 & -102.0 \\
\hline
\end{tabular}

Source: O’Donoghue, Baldini and Mantovani (2004) Tables 10c, p. 35.

117. Further research is currently devoted to enhancing the modelling of consumption taxes within EUROMOD. To this end, Decoster et al (2007) ${ }^{64}$ are studying the incidence of consumption tax in Belgium using an enhanced model of consumption taxes relative to that used in O'Donoghue et al (2004); and their results ${ }^{65}$ point to greater regressivity compared to those provided by O'Donoghue et al (2004) for Belgium (Figure 12). This difference is not explained either by the $50 \%$ underreporting of VAT nor by the around 4-times over-attribution of excises to households in O'Donoghue et al (2004) as evident in Table 5.

64. See $<$ http://www.econ.kuleuven.be/CES/discussionpapers/Dps07/Dps0711.pdf $>$

65. The equivalence scale adopted is the square root of the number of household members. Various other inequality measures are reported in the paper but not noted in this review. 


\section{Other comparative studies}

118. Other studies have compared the performance of pairs of countries. Harding, Lloyd and Warren (2006, 2007) compare tax and transfer incidence in Australia and the United Kingdom for 2001-02 and conclude that this is surprisingly similar in the two countries (Figure 13). Estimates for both countries modelled consumption taxes using input-output data.

Table 8. A comparison of estimates of the incidence of taxes based on different models for Belgium

Estimates from EUROMOD for 1998 and ASTER/MISIM for 2001

\begin{tabular}{|c|c|c|c|c|c|c|c|c|}
\hline \multirow[b]{2}{*}{ Decile } & \multicolumn{5}{|c|}{ Taxes and contributionsas \% of disposable income } & \multicolumn{3}{|c|}{ Taxes and contributionsas $\%$ of gross income } \\
\hline & Own contributions & $\begin{array}{c}\text { Personal } \\
\text { income taxes }\end{array}$ & Indirect taxes & $\begin{array}{l}\text { Global taxes and } \\
\text { contributions }\end{array}$ & Own contributions & $\begin{array}{c}\text { Personal } \\
\text { income taxes }\end{array}$ & Indirect taxes & $\begin{array}{c}\text { Global taxes and } \\
\text { contributions }\end{array}$ \\
\hline 1 & 1.2 & -0.2 & 11.4 & 12.4 & 1.3 & -0.2 & 12.2 & 13.4 \\
\hline 2 & 5.8 & 2.8 & 10.8 & 19.5 & 5.9 & 2.8 & 10.9 & 19.6 \\
\hline 3 & 8.7 & 8.7 & 10.5 & 27.8 & 8.0 & 8.0 & 9.8 & 25.8 \\
\hline 4 & 10.8 & 15.2 & 10.5 & 36.5 & 9.4 & 13.2 & 9.1 & 31.6 \\
\hline 5 & 11.9 & 18.1 & 10.2 & 40.2 & 10.0 & 15.3 & 8.6 & 33.9 \\
\hline 6 & 13.3 & 23.5 & 10.0 & 46.9 & 10.6 & 18.7 & 8.0 & 37.4 \\
\hline 7 & 14.0 & 27.5 & 9.7 & 51.3 & 10.9 & 21.3 & 7.5 & 39.7 \\
\hline 8 & 14.4 & 31.1 & 9.5 & 55.0 & 10.8 & 23.3 & 7.2 & 41.2 \\
\hline 9 & 15.7 & 35.3 & 9.3 & 60.3 & 11.5 & 25.8 & 6.8 & 44.0 \\
\hline 10 & 15.6 & 41.9 & 8.6 & 66.1 & 11.0 & 29.6 & 6.1 & 46.7 \\
\hline All individuals & 12.8 & 25.8 & 9.7 & 48.2 & 10.1 & 20.4 & 7.7 & 38.3 \\
\hline
\end{tabular}

Source: Decoster, De Swerdt and Verbist (2007), Table 5.

Figure 12. The distributive profile of consumption taxes in Belgium based on different models and definitions of household income

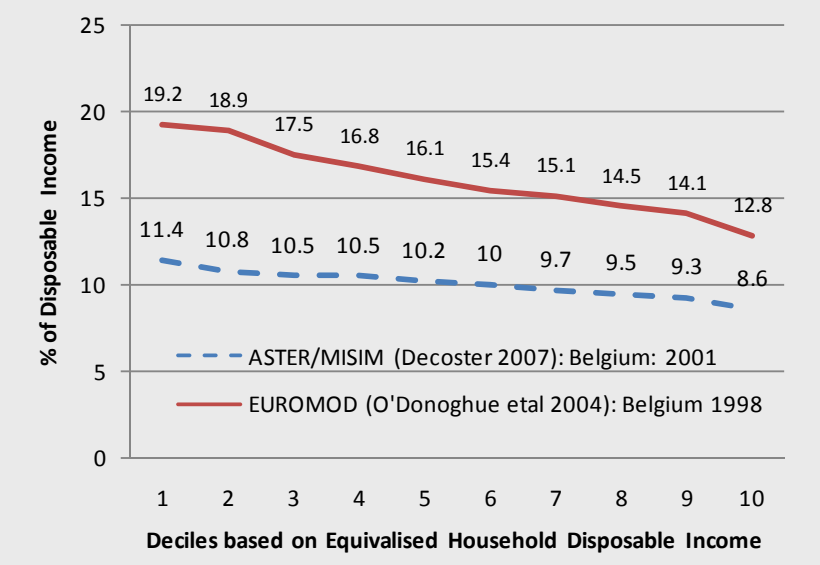

Source: Decoster, De Swerdt and Verbist (2007), Table 5.

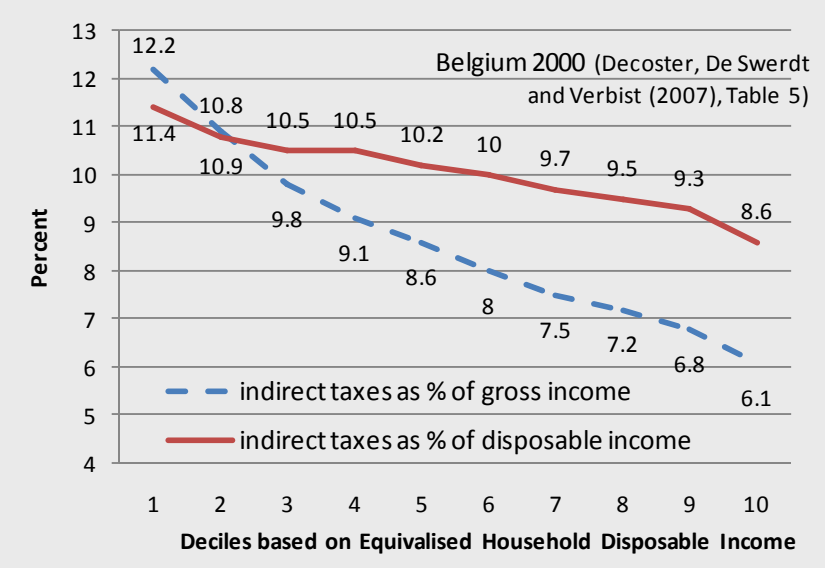


Figure 13. A comparison of the incidence of consumption taxes in Australia and the United Kingdom, 2001-02

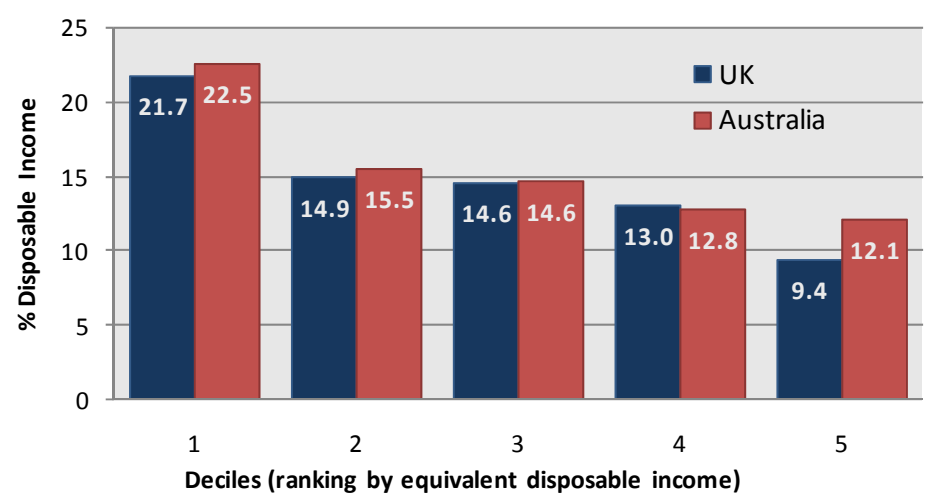

Source: Harding, Lloyd and Warren (2006, 2007), Table 1.

\section{Controlled hypothetical estimates of consumption tax incidence in OECD countries}

119. The above discussion highlights the lack of an agreed approach to modelling the distributional impact of consumption taxes on individuals. The reason for this outcome is relatively simple - the paucity of data necessary to facilitate the adoption of the preferred methodology. In particular, the lack of ready access to both input-output tables and household surveys providing information on both income and expenditure.

120. The purpose of this section is to provide a limited insight into the distributional implications of including consumption taxes in studies which had previously only included personal income taxes. The objective is to demonstrate the vital importance of moving to include some consideration of consumption taxes in such studies. The approach taken will be to build on previous OECD research which examined the distributional impact of personal income taxes, cash benefits and in-kind services from governments, on the distribution of household income across OECD countries. The approach taken is based on a number of "what if" scenarios designed to demonstrate the broad direction and magnitude of the impact of consumption taxes on income distribution. While such an approach cannot inform us about the precise impact of consumption taxes in each of the OECD countries considered, it will serve to demonstrate the importance of including consumption taxes in any comparative assessment of the effect of government tax and welfare policies on income inequality.

\subsection{Methodology}

121. The methodology adopted is relatively simple - and with this simplicity comes a number of important qualifications to the results obtained. As a first step, the data in Förster and Mira d'Ercole (2005) and Marical, Mira d'Ercole, Vaalavuo and Verbist (2006) was formed into decile groupings based on individuals' adjusted household disposable income, where the adjustment was based on the square root of the number of individuals in each household. The deciles therefore represent deciles of equivalent individuals. For each decile, data refers to the average value of household disposable income, public cash transfers, personal income taxes (including social security contribution paid by workers) and in-kind public services.

122. The second step was to develop measures of effective consumption tax rates that could be applied to these estimates of disposable income by decile groupings. The approach taken was to draw on the consumption tax incidence estimates for Australia by Harding, Lloyd and Warren (2006) and recast them 
into the same format as that by Förster and Mira d'Ercole (2005): individuals are ranked and grouped into deciles using disposable income divided by the square root of the household size; and then for each decile, the ratio of consumption tax to disposable income was estimated.

123. Since Harding, Lloyd and Warren (2006) were examining the distributional impact of reforms introduced in Australia in July 2000 (the introduction of a 10\% GST in place of a multi-rate Wholesale Sales Tax), two consumption tax regimes were modelled - that pre the reform (1994-95) and that post the reform (2001-02). It was the results from these two consumption tax regimes that were applied to the income distribution data available from Förster and Mira d'Ercole (2005).

- For Australia, as the data on household income in Förster and Mira d'Ercole (2005) refer to 1998-99 - which was before the introduction of the 10\% GST - the Australian consumption tax results for 1994-95 were 'adjusted' to 1998-99 to determine the consumption tax burden on Australian households in that year. These adjustments made to the results in Harding, Lloyd and Warren (2006) are relatively basic. The consumption tax incidence estimates for 1994-95 were adjusted to 1998-99 by first separating consumption taxes into those on Taxes on General Consumption (OECD Classification 5110) and on Taxes on Specific Goods and Services (OECD Classification 5120). Then, the Australian 1994-95 tax rates on disposable income were adjusted up to 1998-99 values based on change in the ratio of each of these tax groupings to GDP, over the period 1995 and 1999 as reported in OECD Revenue Statistics.

- For all other OECD countries, estimates of the incidence of their consumption taxes were based on 'adjusted' Australian VAT/GST and Excise estimates for 2001-02. ${ }^{66}$ The adjustment was in two steps. Firstly, the 2001-02 Australian incidence data on Taxes on General Consumption and Taxes on Specific Goods and Services were applied to people in each decile from Förster and Mira d'Ercole (2005). Secondly, for each of these two consumption tax categories, the Australian rates were adjusted by the ratio of each country's tax to GDP relative to that in Australia in $2002{ }^{67}$ This implies making a simple shift in the rates across all deciles to reflect the overall level (relative to GDP) of the taxes paid under each of the different consumption tax regimes. While this approach takes account of differences in the mix of VAT and excise in each country, it ignores cross-country differences in rates and base of either the excise or VAT/GST, as well as differences in the consumption-to-income ratios across countries. Essentially, only differences in the level of these two consumption taxes in each country are considered.

124. The third step was to apply these adjusted tax rates to the disposable income of the different decile groupings in each country as reported in Förster and Mira d'Ercole (2005). This resulted in an estimate of the nominal burden of taxes on Taxes on General Consumption and Taxes on Specific Goods and Services for those at different points in the income distribution. These data were then combined with those on disposable income, public cash transfers, personal income taxes and in-kind public services to evaluate the 'what if' scenarios outlined below.

66. Complications arise in the case of the USA which has State based sales taxes with various exemptions and refundable and non-refundable tax credit regimes. While the Australian VAT/GST - which is imposed at a rate of $10 \%$ and zero-rates basic food, health and education - does not reflect the multi-rate VAT structures in other OECD countries, the aim of this exercise is not to model consumption tax incidence for each country but rather to demonstrate the importance of including regressive consumption taxes when studying the distributive impact of government tax and benefits.

67. For example, the data for France has the year 2000 as its base year in Förster and Mira d'Ercole (2005). The approach taken estimates the 2000 distribution of France's Taxes on General Consumption (5110) across deciles as equal to the 2001-02 distribution of Australia's Taxes on General Consumption (5110) multiplied by the ratio of France's Taxes on General Consumption (5110) to GDP in 2000, relative to Australia's ratio of Taxes on General Consumption (5110) to GDP in 2002. 


\subsection{What if consumption taxes were included in a broader measure of household disposable income?}

125. Table 9 details the Gini index for household disposable income (Case 1: DY), as reported by Förster and Mira d'Ercole, 2005) and the disposable income plus in-kind public services (Case 2: DY+IK) as reported by Marical, Mira d'Ercole, Vaalavuo and Verbist (2006). As both studies exclude consumption taxes, the interesting question is: 'What implications does including consumption taxes have for estimates of the distributional impact of government on an individual's disposable income?'

126. A simple approach to answering this question is to examine the impact of incorporating consumption taxes (CT) into an adjusted disposable income measure. Case 3 is hence a variant of Case 1 where $\mathrm{DY}^{*}=\mathrm{DY}-\mathrm{CT}$, and Case 4 a variant of Case 2 where DY' $=\mathrm{DY}+\mathrm{IK}-\mathrm{CT}$

127. The findings for Case 3 are shown in Figure 14 (and Table 9) and indicate that consumption taxes (CT) are clearly regressive (the Gini coefficients for DY* are always above those for DY, with an increase for Australia of 0.014 points or some 5\%). Figure 15 shows the impact of consumption taxes on the share of income received by different deciles always using Case 3 . In general, the income share of the $1^{\text {st }}$ decile relative to that of the $5^{\text {th }}$ decile falls moderately with the inclusion of consumption taxes, while the share of the $9^{\text {th }}$ decile relative to the $5^{\text {th }}$ increases much more significantly. At its simplest, the inclusion of consumption taxes results in the "poor getting poorer, the rich getting richer and the gap between the rich and poor widening'.

128. What are the broad implications of consumption taxes for a study which includes in-kind public transfers in addition to cash transfers such as Marical et al. (2006)? Table 9 reports values of the Gini index for disposable income broadened to include in-kind public services - Case 4 - and Figure 16 maps the findings. In-kind public services generally reduce the Gini index of income inequality: including consumption taxes partly offsets the positive redistributive effects of in-kind public services. This offset is on average only some $9 \%$ of the impact of including in-kind services, but as much as $22 \%$ for Turkey and $18 \%$ for Mexico, Netherlands and Greece and only 2\% in the United States, and 3\% in Australia, Japan and Sweden.

129. If changes in the tax mix across time and between countries were similar, the exclusion of consumption taxes would lead to errors of the same size over time and across countries. However, the evidence in Section 2.2 does not support this position. What is apparent is that the impact of consumption taxes differs widely across countries and over time. This could reflect differences in the mix of these taxes (e.g. VAT vs Excise), their size (e.g. CT/GDP) and their contributions to total government taxation (e.g. CT/Total Tax). Figure 14 and Table 9 illustrate the interaction of these three factors but there is limited scope for generalisations across countries without a closer examination of the size of each factor. Moreover, the modelling approach adopted here does not consider the important differences arising from consumption patterns varying across income deciles in each country and from differences in the base and rate of the different consumption tax regimes.

130 What can be deduced from our limited results is that, being regressive - regardless of its particular design attributes - the higher the level of consumption tax, the greater its adverse impact on the post-tax income distribution. This suggests that a change in the tax mix towards consumption taxes will make the post-tax distribution of income more unequal in the absence of countervailing changes to progressive taxes or to the distribution of government expenditure. It also highlights the need to complement any analysis of the distributional impact of consumption taxes with the measures used to compensate for the adverse distributional impact of such taxes including personal income tax reductions and increases in welfare payment. 


\section{Figure 14. The impact of consumption taxes on income inequality in selected OECD countries}

Income inequality as measured by the Gini coefficient, Cases 1 and 3

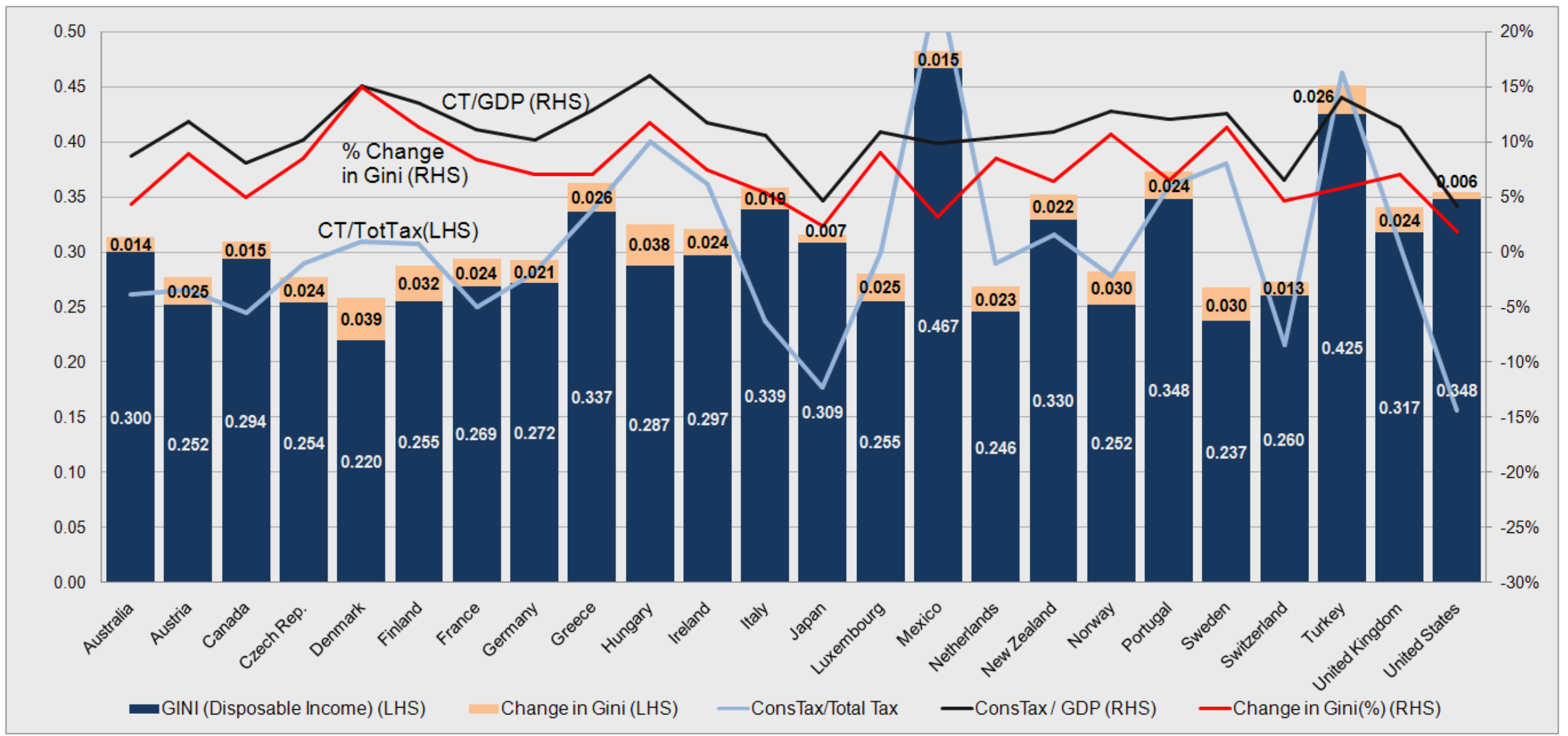

Source: Author's calculations. 
Figure 15. Changes in ratios of relative economic well-being due to consumption taxes

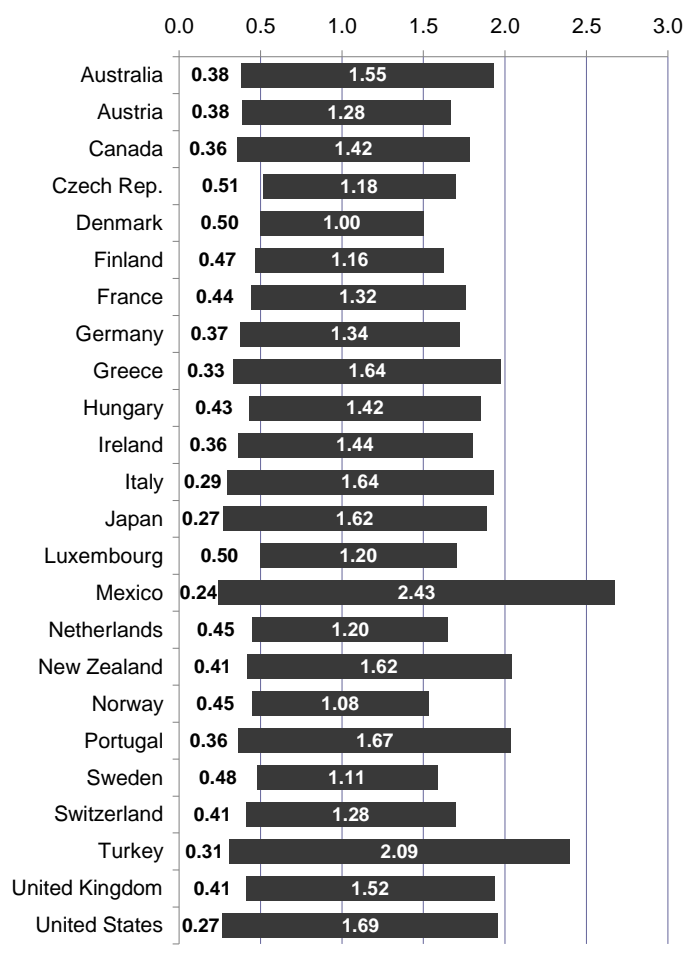

10/50 (DY) 90/50 less 10/50 (DY)

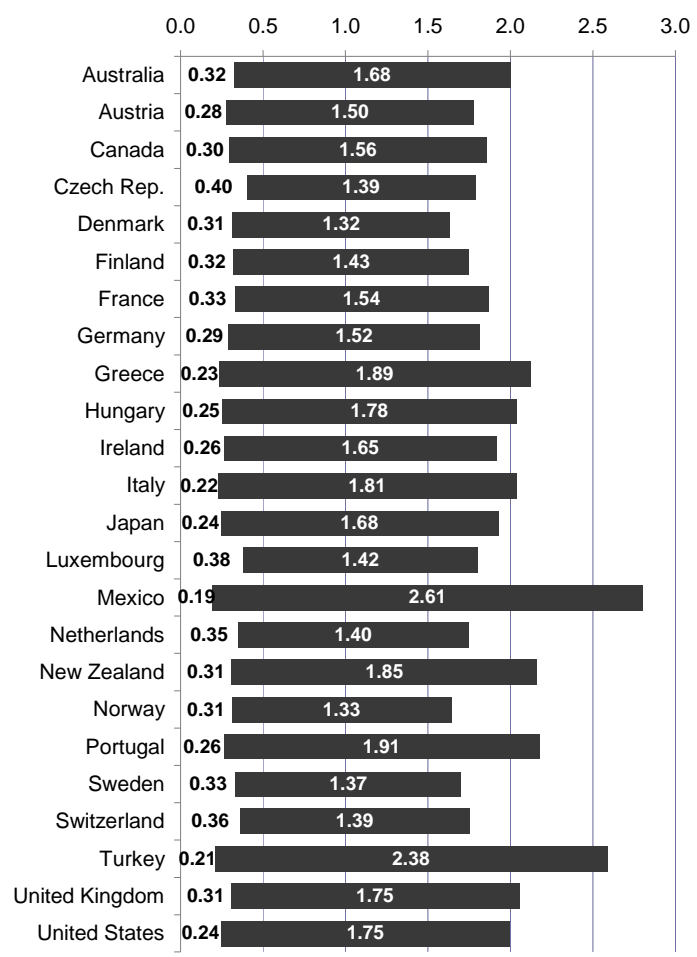

10/50 (DY-CT) = 90/50 less 10/50 (DY-CT)

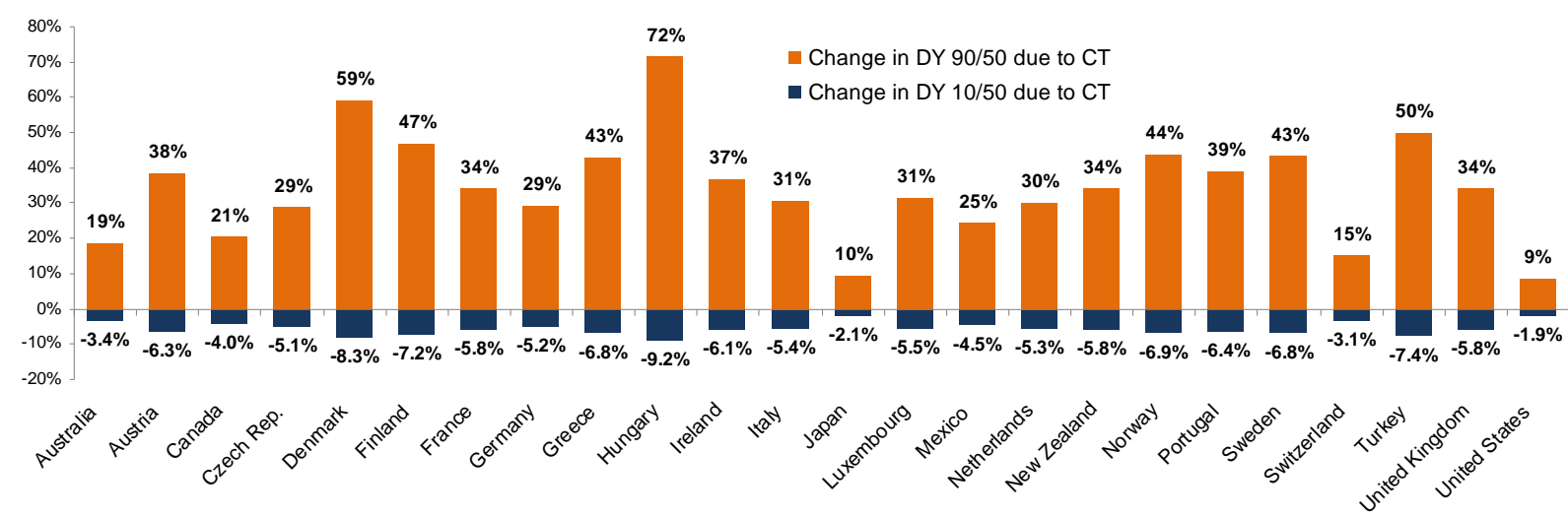

Source: Author's calculations. 
Figure 16. The impact on income inequality of consumption taxes and in-kind public services in selected OECD countries Income inequality as measured by the Gini coefficient, Cases 4 and $4 \mathrm{~A}$

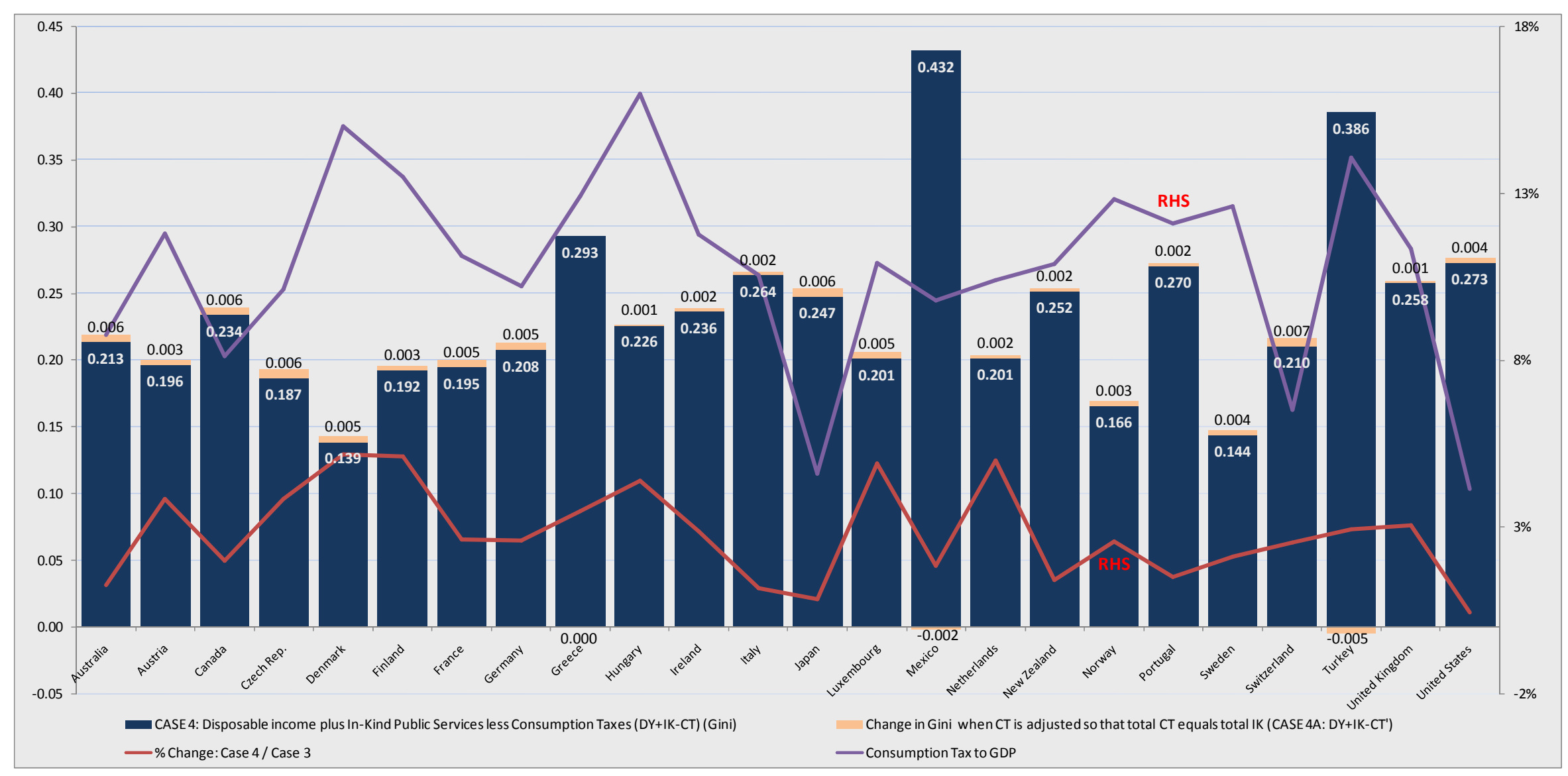

Source: Author's calculations. 
Table 9. Redistributive effects of different government policies in selected OECD countries

Redistributive effects based on Lorenz-curve inequality measures

\begin{tabular}{|c|c|c|c|c|c|c|c|c|c|c|c|c|c|c|c|c|c|c|c|c|c|c|c|c|}
\hline & Australia & Austria & Canada & $\begin{array}{l}\text { Czech } \\
\text { Rep. }\end{array}$ & Denmark & Finland & France & Sermany & Greece & Hungary & Ireland & Italy & Japan & nbourg & Mexico I & erlands & $\begin{array}{r}\text { New } \\
\text { Zealand }\end{array}$ & Norway & Portugal & Sweden & itterland & Turkey & $\begin{array}{l}\text { United } \\
\text { Kingdom }\end{array}$ & $\begin{array}{l}\text { United } \\
\text { States }\end{array}$ \\
\hline & 1998/99 & 1999 & 2000 & 2002 & 2000 & 2000 & 2000 & 2001 & 1999 & 2000 & 2000 & 2000 & 2000 & 2001 & 2002 & 2000 & 2000/01 & 2000 & 2000 & 2000 & 2001 & 2002 & 2000 & 2000 \\
\hline oncentration Curve Indices & & & & & & & & & & & & & & & & & & & & & & & & \\
\hline Private Income (PY) & 0.450 & & 0.385 & & 0.375 & 0.365 & 0.381 & 0.392 & & & 0.407 & 0.430 & 0.357 & & & 0.360 & 0.449 & 0.377 & 0.416 & 0.395 & 0.298 & & 0.453 & 0.439 \\
\hline Public cash transfers $(\mathrm{PC})$ & -0.387 & & -0.120 & & -0.292 & -0.230 & 0.030 & -0.005 & & & -0.226 & 0.148 & 0.032 & & & -0.221 & -0.307 & -0.207 & 0.151 & -0.143 & 0.006 & & -0.285 & -0.088 \\
\hline Gross Income (GY) & 0.349 & & 0.328 & & 0.264 & 0.295 & 0.284 & 0.315 & & & 0.326 & 0.369 & 0.310 & & & 0.278 & 0.368 & 0.287 & 0.372 & 0.276 & 0.252 & & 0.351 & 0.403 \\
\hline Income and payroll taxes (YT) & 0.545 & & 0.446 & & 0.348 & 0.419 & 0.449 & 0.428 & & & 0.493 & 0.474 & 0.319 & & & 0.371 & 0.505 & 0.388 & 0.508 & 0.360 & 0.228 & & 0.508 & 0.573 \\
\hline CASE 1: Disposable Income (DY) (Gini) & 0.300 & 0.252 & 0.294 & 0.254 & 0.220 & 0.255 & 0.269 & 0.272 & 0.337 & 0.287 & 0.297 & 0.339 & 0.309 & 0.255 & 0.467 & 0.246 & 0.330 & 0.252 & 0.348 & 0.237 & 0.260 & 0.425 & 0.317 & 0.348 \\
\hline In-Kind Public Senvices (IK) & -0.108 & -0.049 & -0.018 & -0.084 & -0.108 & -0.081 & -0.052 & -0.042 & 0.007 & -0.041 & -0.061 & -0.047 & -0.026 & -0.073 & 0.020 & -0.071 & -0.075 & -0.105 & -0.042 & -0.098 & -0.057 & -0.026 & -0.084 & -0.070 \\
\hline $\begin{array}{l}\text { CASE 2: Disposable Income plus In-Kind Public } \\
\text { Services (DY+IK) (Gini) }\end{array}$ & 0.211 & 0.189 & 0.229 & 0.180 & 0.132 & 0.183 & 0.190 & 0.203 & 0.283 & 0.217 & 0.230 & 0.261 & 0.245 & 0.192 & 0.424 & 0.192 & 0.248 & 0.162 & 0.266 & 0.141 & 0.205 & 0.375 & 0.250 & 0.272 \\
\hline$\%$ Change: Case $2 /$ Case 1 & $-29.7 \%$ & $-24.9 \%$ & $-22.0 \%$ & $-29.2 \%$ & $-39.9 \%$ & $-28.1 \%$ & $-29.5 \%$ & $-25.5 \%$ & $-15.9 \%$ & $-24.6 \%$ & $-22.7 \%$ & $-23.1 \%$ & $-20.5 \%$ & $-24.9 \%$ & $-9.1 \%$ & $-21.9 \%$ & $-24.8 \%$ & $-36.0 \%$ & $-23.5 \%$ & $-40.7 \%$ & $-21.2 \%$ & $-11.9 \%$ & $-21.2 \%$ & $-21.9 \%$ \\
\hline insumption Taxes (CT) & 0.181 & 0.149 & 0.189 & 0.133 & 0.101 & 0.137 & 0.158 & 0.167 & 0.234 & 0.180 & 0.193 & 0.240 & 0.211 & 0.133 & 0.366 & 0.133 & 0.227 & 0.139 & 0.244 & 0.124 & 0.150 & 0.326 & 0.206 & 0.250 \\
\hline $\begin{array}{l}\text { CASE 3: Disposable Income less Consumption } \\
\text { Taxes (DY-CT) (Gini) }\end{array}$ & 0.313 & 0.277 & 0.309 & 0.277 & 0.258 & 0.287 & 0.293 & 0.292 & 0.362 & 0.325 & 0.321 & 0.358 & 0.316 & 0.281 & 0.482 & 0.268 & 0.352 & 0.283 & 0.373 & 0.267 & 0.273 & 0.452 & 0.341 & 0.355 \\
\hline$\%$ Change: Case $3 /$ Case 1 & $4.6 \%$ & $9.8 \%$ & $5.2 \%$ & $9.3 \%$ & $17.6 \%$ & $12.7 \%$ & $9.1 \%$ & $7.6 \%$ & $7.6 \%$ & $13.2 \%$ & $8.0 \%$ & $5.7 \%$ & $2.4 \%$ & $9.9 \%$ & $3.3 \%$ & $9.3 \%$ & $6.8 \%$ & $11.9 \%$ & $7.0 \%$ & $12.7 \%$ & $4.9 \%$ & $6.1 \%$ & $7.5 \%$ & $1.9 \%$ \\
\hline $\begin{array}{l}\text { CASE 4: Disposable income plus In-Kind Public } \\
\text { Services less Consumption Taxes (DY+|K-CT) }\end{array}$ & 0.213 & 0.196 & 0.234 & 0.187 & 0.139 & 0.192 & 0.195 & 0.208 & 0.293 & 0.226 & 0.236 & 0.264 & 0.247 & 0.201 & 0.432 & 0.201 & 0.252 & 0.166 & 0.270 & 0.144 & 0.210 & 0.386 & 0.258 & 0.273 \\
\hline \% Change: Case $4 /$ Case 2 & $1.3 \%$ & $3.8 \%$ & $2.0 \%$ & $3.8 \%$ & $5.2 \%$ & $5.1 \%$ & $2.6 \%$ & $2.6 \%$ & $3.5 \%$ & $4.4 \%$ & $2.9 \%$ & $1.2 \%$ & $0.8 \%$ & $4.9 \%$ & $1.8 \%$ & $5.0 \%$ & $1.4 \%$ & $2.6 \%$ & $1.5 \%$ & $2.1 \%$ & $2.5 \%$ & $2.9 \%$ & $3.0 \%$ & $0.4 \%$ \\
\hline $\begin{array}{l}\text { Hypothetical Cases } \\
\text { CASE 1A: DY+YT-(YT'+CT') (where YT is replaced }\end{array}$ & & & & & & & & & & & & & & & & & & & & & & & 034 & \\
\hline $\begin{array}{l}\text { CASE 1A: DY+YT-(YT'+CT') (where YT is replaced } \\
\text { by an equal revenue combination of YT and CT) } \\
\% \text { Change: Case } 1 \mathrm{~A} / \text { Case } 1\end{array}$ & 0.326 & & 0.317 & & 0.261 & 0.291 & 0.287 & 0.302 & & & 0.324 & 0.363 & 0.314 & & & 0.273 & 0.360 & 0.285 & 0.372 & 0.271 & 0.267 & & 0.346 & 0.365 \\
\hline \% Change: Case $1 \mathrm{~A} /$ Case 1 & $8.9 \%$ & & $7.8 \%$ & & $18.9 \%$ & $14.4 \%$ & $6.6 \%$ & $11.0 \%$ & & & $9.1 \%$ & $7.2 \%$ & $1.8 \%$ & & & $11.0 \%$ & $9.2 \%$ & $12.8 \%$ & $6.9 \%$ & $14.4 \%$ & $2.4 \%$ & & $9.2 \%$ & $4.8 \%$ \\
\hline $\begin{array}{l}\text { CASE 4A: DY+IK-CT' (where CT is adjusted so IK } \\
\text { is funded with CT-like taxes) (Gini) }\end{array}$ & 0.219 & 0.200 & 0.240 & 0.193 & 0.143 & 0.195 & 0.200 & 0.213 & 0.293 & 0.227 & 0.238 & 0.266 & 0.253 & 0.206 & 0.430 & 0.204 & 0.253 & 0.169 & 0.272 & 0.148 & 0.217 & 0.381 & 0.259 & 0.277 \\
\hline Selected tax ratios & $2.7 \%$ & 1.6 & $2.5 \%$ & $\%$ & $3.3 \%$ & $1.6 \%$ & $2.8 \%$ & $2.3 \%$ & $-0.1 \%$ & 0 & $\%$ & $0.8 \%$ & $2.4 \%$ & $2.3 \%$ & -0.4 & $1.2 \%$ & $0.7 \%$ & $2.1 \%$ & $0.7 \%$ & $2.7 \%$ & $3.1 \%$ & $-1.3 \%$ & $0.5 \%$ & $1.4 \%$ \\
\hline CT/GDP & $8.8 \%$ & $11.8 \%$ & $8.1 \%$ & $10.1 \%$ & $15.0 \%$ & $13.5 \%$ & $11.1 \%$ & $10.2 \%$ & $12.9 \%$ & $16.0 \%$ & $11.8 \%$ & $10.6 \%$ & 4.6 & 109 & 9.8 & $10.4 \%$ & $10.9 \%$ & $128 \%$ & $121 \%$ & $126 \%$ & $6.5 \%$ & $14.1 \%$ & 113 & \\
\hline$\%$ conts & $48 \%$ & $71 \%$ & $63 \%$ & $63^{\circ}$ & $64 \%$ & $62 \%$ & $67 \%$ & $66 \%$ & $62 \%$ & $71 \%$ & 62 & $62^{\circ}$ & 53 & 57 & 38 & $66 \%$ & & 68 & $66 \%$ & 71 & $62 \%$ & $58 \%$ & $59 \%$ & $55 \%$ \\
\hline$\%$ cont & $52 \%$ & $29 \%$ & $37 \%$ & $37^{\circ}$ & $36 \%$ & $38 \%$ & $33 \%$ & $34 \%$ & $38 \%$ & $29 \%$ & $38 \%$ & $38 \%$ & 47 & 43 & $62^{\circ}$ & 34 & & 32 & 34 & 29 & & $42 \%$ & $41 \%$ & $45 \%$ \\
\hline CT/Total Taxtion & $26 \%$ & $27 \%$ & $24 \%$ & $29 \%$ & $31 \%$ & $31 \%$ & $25 \%$ & $28 \%$ & $34 \%$ & $40 \%$ & $36 \%$ & $24 \%$ & $18 \%$ & $30 \%$ & $55 \%$ & $29 \%$ & $32 \%$ & $28 \%$ & $36 \%$ & $38 \%$ & $22 \%$ & $46 \%$ & $31 \%$ & $16 \%$ \\
\hline 0 of In-Kind Publi & & & 0 & & 069 & 0.83 & 358 & 074 & & & 134 & 088 & 128 & & & 0.59 & 0.90 & 100 & 154 & 0.87 & 0.62 & & 0.94 & 69. \\
\hline Income (IKIDY) & 0.28 & 0.26 & 0.26 & 0.28 & 0.37 & 0.27 & 0.33 & 0.28 & 0.19 & 0.27 & 0.23 & 0.25 & 0.23 & 0.24 & 0.11 & 0.20 & 0.25 & 0.34 & 0.27 & 0.40 & 0.21 & 0.13 & 0.20 & 0.22 \\
\hline Ratio o & & & & & & & & & & & & & & & & & & & & & & & & \\
\hline Personal & $\begin{array}{l}0.42 \\
0.10\end{array}$ & 0.19 & $\begin{array}{l}0.44 \\
0.13\end{array}$ & 0.1 & $\begin{array}{l}0.46 \\
0.25\end{array}$ & 0.22 & 0.18 & 0.16 & & & $\begin{array}{l}1.0 \\
0.15\end{array}$ & 0.16 & 0.0 & & & $\begin{array}{l}0.49 \\
0.17\end{array}$ & 0.18 & 0.21 & 0.19 & 0.21 & $\begin{array}{l}0.31 \\
0.10\end{array}$ & & $\begin{array}{l}0.82 \\
0.18\end{array}$ & 0.19 \\
\hline $\begin{array}{r}\text { Disposable Income (CT/DY) } \\
\text { In-Kind Public Services (CT//K) }\end{array}$ & $\begin{array}{l}0.10 \\
0.37\end{array}$ & $\begin{array}{l}0.79 \\
0.74\end{array}$ & 0.49 & 0.58 & 0.67 & 0.80 & 0.55 & 0.58 & 1.03 & $\begin{array}{l}0.96 \\
0.95\end{array}$ & 0.80 & 0.64 & 0.30 & $\begin{array}{l}0.72 \\
0.72\end{array}$ & $\begin{array}{l}0.13 \\
1.25\end{array}$ & 0.83 & 0.71 & 0.62 & 0.72 & 0.52 & $\begin{array}{l}0.10 \\
0.49\end{array}$ & $\begin{array}{l}0.27 \\
1.64\end{array}$ & $\begin{array}{l}0.18 \\
0.88\end{array}$ & $\begin{array}{l}0.06 \\
0.28\end{array}$ \\
\hline Cash Trans & & & & & & & & & & & & & & & & & & & & & & & & \\
\hline Personal I & 61 & & 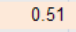 & & 40 & 40 & 3.28 & 0.70 & & & & 0. & & & & & & & 1.13 & 0.7 & 0 & & 78 & 28 \\
\hline & 14 & & 13 & & 0 & 0. & 0.38 & 00 & & & & 0.2 & & & & & & & & & 0.1 & & & 07 \\
\hline & & 0.62 & 0 & 0.8 & 0.70 & 0 & 0.92 & & & & & 1 & & & & & & & & & & 0.15 & & \\
\hline T) & 46 & 84 & 14 & 1.46 & 1.04 & 0.72 & 1.67 & 1.63 & 1.08 & 1.26 & 0.80 & 1.72 & 2.44 & 1.43 & 0.43 & 1.12 & 0.76 & 0.98 & 1.02 & 1.54 & 2.01 & 0.09 & 0.95 & 1.47 \\
\hline
\end{tabular}

Source: Author's calculations. 


\subsection{What if consumption taxes fund selected government transfers?}

129. The challenge when comparing Cases $1,2,3$ and 4 in Table 9 is that the aggregate income measure differs in all cases, varying from DY in Case 1, (DY+IK) in Case 2, (DY-CT) in Case 3 to $(\mathrm{DY}+\mathrm{IK}-\mathrm{CT})$ in Case 4. This makes comparisons difficult since each case reflects changes in both the distribution and level of income.

130. An approach to overcoming this problem is to set as constant the aggregate level of income being distributed between individuals in the cases being compared. Below we apply this approach to Cases 1 and 4 by posing the following questions.

- Case 1A: What if personal income taxes are replaced by an equal aggregate value combination of personal income taxes and consumption taxes? ${ }^{68}$ This case provides insight into the implications of including a mix of personal income and consumption taxes to fund a given level of tax revenue, rather than just personal income taxes.

- Case 4A: What if all in-kind public services were entirely funded by consumption-like taxes? ${ }^{69}$ This is a variant on Case 4, this time providing some insight into the implications of fully funding IK through consumption taxes.

131. The results from these two cases are presented in Table 9. Case1A results highlight the implications of replacing personal income taxes with an equal-revenue combination of personal income and consumption taxes but where the mix is in line with the current mix of personal income and consumption taxes in each country. In this case the Gini index of disposable income rises across the 17 countries (Table 9), suggesting a worsening in the distribution of disposable income ranging between $1.8 \%$ for Japan and $18.9 \%$ for Denmark, with an average change of $9 \%$. Clearly, the mix of taxes considered when estimating disposable income directly and significantly affects measured income inequality.

132. Case 4A models the implication of fully funding the provision of in-kind services (IK) through consumption-like taxes. The findings in Table 9 are that this erodes the distributional benefits arising from in-kind benefits (with two exceptions), by up to $3.3 \%$ in the case of Denmark.

133. While the methodology applied in this section has obvious limits, the clear conclusion is that caution needs to be taken when comparing the size of government redistribution in different countries when those differences might simply reflect the partial coverage of taxes (such as when consumption taxes are excluded) and government expenditures (where in-kind public services are excluded).

\section{The way forward}

134. The discussion in this paper has clearly indicated that consumption taxes have a regressive impact on the distribution of household annual income - even despite methodological differences across studies. This contrasts with the equalising impact of personal income taxes, which fall more heavily on the higher income groups. This contrast implies that any study of the distributional impact of government activities based on personal income taxes alone will misrepresent the overall impact of all taxation.

68. In this case: $\mathrm{DY} \mathrm{i}^{\prime}=\mathrm{DY} \mathrm{H}+\mathrm{YTi}-\left(\mathrm{YTi}^{\prime}+\mathrm{CTi}^{\prime}\right)$ where overall $\Sigma \mathrm{YTi}^{\prime}+\Sigma \mathrm{CT} \mathrm{i}^{\prime}=\Sigma \mathrm{YTi}$ and $\Sigma \mathrm{DYi}{ }^{\prime}=\Sigma \mathrm{DYi}$ where YT and $\mathrm{CT}$ are included in $-\left(\mathrm{YTi}^{\prime}+\mathrm{CTi}^{\prime}\right)$ in proportion to their respective contributions to the total of these two taxes.

69. In this case: $\mathrm{DY} \mathrm{i}^{\prime}=\mathrm{DY} \mathrm{D}+\left(\mathrm{IKi}-\mathrm{CTi}{ }^{\prime}\right)$ where overall $\Sigma \mathrm{CTi}=\Sigma \mathrm{IKi}$ and $\Sigma \mathrm{DY} \mathrm{i}^{\prime}=\Sigma \mathrm{DY} \mathrm{i}$. 
135. What this paper has demonstrated is that while there is a diversity of approaches currently used to estimate consumption tax incidence, such differences reflect more data availability than fundamental differences of opinion as to the preferred methodological approach. There is indeed increasing support for the methodological approach, based on input-output tables, adopted by government statisticians in Australia (ABS, 2006), Canada (SPSD/M) and the United Kingdom (ONS, 2007) to estimate consumption tax burdens. What has constrained the wider adoption of this approach is the complexity of the approach and its significant data demands.

136. As an alternative to complex input-output based models, a number of comparative studies have opted for a simpler approach, based on household expenditure surveys and tax rates data. The application of such an approach to LIS data and its incorporation into EUROMOD has led to variable results described in Section 4. Section 5 has outlined an alternative approach which provides some insight into the effect of consumption taxes on the distribution of income across OECD countries: such approach applied the findings on the consumption tax incidence from one country to other countries.

137. While the approach taken is far from perfect, it can be refined as information comparable to that for Australia becomes available for other countries. Of particular importance is to overcome the limitations implicit in ignoring cross-country differences in consumption tax rates and base, as well as differences in consumption patterns across income groups in the various countries. Nonetheless, this approach is conceptually similar to that applied by Garfinkel Rainwater and Smeeding (2004) to LIS data, where the findings from selected countries were applied to other countries studied. Further refinements to EUROMOD could provide one such framework for comparative analysis of consumption tax incidence.

138. Another issue complicating international comparisons of consumption tax incidence estimates (as highlighted in Table 5) is the widely varying coverage of consumption taxes in the different studies. While some studies focus just on excises and others on VAT (or sales taxes) - and then sometimes just on those directly on individuals as consumers - others are more comprehensive, including a range of taxes whose economic (or final) incidence is on consumption. One of the advantages of the methodology outlined in this paper is that it effectively covers all taxes on consumption and production, thus providing a better basis for cross-country comparisons.

139. Two areas stand out as requiring greater efforts in comparative research. The first is analysis of the distributional impact of tax compliance and administrative costs, tax exemptions (or tax expenditures) and of the distortionary impact of taxes. The second is in estimating the lifetime incidence of consumption taxes. While some studies have advocated the use of consumption as the base for assessing the final incidence of consumption taxes, the empirical application of such approach remain limited, with more studies relying on annual income of people by age to control for lifecycle issues. The increased availability of longitudinal survey data will inevitably lead to greater attention to lifetime tax incidence in the future.

140. Despite the limitations of current research, this paper has highlighted the importance of including consumption taxes in any study into the distributional impact of government on individuals. What appears to stand most in the way of progress is not agreement on methodology but access to supporting data, in particular input-output data - to provide insight into the effective tax rates on consumption - and household income and expenditure survey data - to which the tax rates can be applied. This is where government agencies have a key role in supporting further research into this important area. 


\section{BIBLIOGRAPHY}

Aaron, H. and M. McGuire (1970), "Public Goods and Income Distribution”, Econometrica, 36(6): 907920.

Adema, W. (1999), "Net Social Expenditure", Labour Market and Social Policy Occasional Papers, nr.39, OECD, Paris.

Adema, W. and M. Ladaique (2005), "Net Social Expenditure - 2005 edition", OECD Social, Employment and Migration Papers, OECD, Paris.

Adema, W., M. Einerhand, B. Eklind, J. Lotz and M. Pearson (1996), "Net Public Social Expenditure", Labour Market and Social Policy Occasional Papers, nr.19, OECD, Paris.

Adler, J. H. (1951), "The Fiscal System, the Distribution of Income, and Public Welfare," in Fiscal Policies and the American Economy, edited by K. E. Poole. 359-421, Prentice-Hall, New York.

Ahmad, E. and N. Stern (1984), "The Theory of Reform and Indian Indirect Taxes", Journal of Public Economics, 25: 259-298.

Ando, A. and F. Modigliani (1963), "The 'Life Cycle' Hypothesis of Saving: Aggregate Implications and Tests", American Economic Review, 53(1): 55-84.

Annual Statistical Report (2005), Kansas Department of Revenue, Topeka, Kansas.

Antcliff, S. (1993), “An Introduction to Dynamod: A Dynamic Microsimulation Model”, DYNAMOD Technical Paper No 1, September, NATSEM, University of Canberra, Canberra.

Aronson, J.R., P. Johnson and P.J. Lambert (1994), "Redistributive Effect and Unequal Tax Treatment", Economic Journal, 104: 262-270.

Atkinson, A.B. (1970), "On the Measurement of Inequality”, Journal of Economic Theory 2: 244-263.

Atkinson, A.B. (1994), "The Distribution of the Tax Burden" in J. M. Quigley and E. Smolensky (eds.), Modern Public Finance, Harvard University Press, Cambridge, Mass..

Atkinson A.B., L. Rainwater and T. Smeeding (1995), Income Distribution in OECD Countries. Evidence from the Luxembourg Income Study, OECD, Paris.

Atkinson, A. B. and J.E. Stiglitz (1980), Lectures on Public Economics, McGraw-Hill, New York.

Atkinson, A.B. and H. Sutherland (1988), “TAXMOD”, TIDI Paper No. 112, London School of Economics and Political Science, University of London, London.

Atkinson A.B. and H. Sutherland (1988), Tax-Benefit Models, STICERD, London School of Economics, London. 
Atkinson, A.B., J. Gomulka. and H. Sutherland (1988), "Grossing-Up FES data for Tax-Benefit Models", Taxation, Incentives and the Distribution of Income (TIDI) Paper No. 105, London School of Economics and Political Science, University of London, London.

Auerbach, A. J. and L.J. Kotlikoff (1983), "Investment versus Savings Incentives: The Size of the Bang for the Buck and the Potential for Self-Financing Business Tax Cuts", In The Economic Consequences of Government Deficits, edited by L. H. Meyer. Kluwer-Nijhoff, Boston.

Auerbach, A. J. and L.J. Kotlikoff (1987), Dynamic Fiscal Policy. Cambridge University Press, Cambridge.

Australian Bureau of Statistics (2006), Cat 6537.0 - Government Benefits, Taxes and Household Income, Australia, 2003-04<http://www.abs.gov.au/AUSSTATS/abs@.nsf/DetailsPage/6537.0200304 ?OpenDocument>

Australian Bureau of Statistics (2007), Cat 1351.0.55.012 - Research Paper: Review of Methodology for Estimating Taxes on Production in the Calculation of Household Final Income, Apr 2006 $<$ http://www.abs.gov.au/AUSSTATS/abs@.nsf/DetailsPage/1351.0.55.012Apr\%202006?OpenDocu ment>

Australian Bureau of Statistics (2007), Cat. No. 6523.0 Household Income and Income Distribution, Australia, 2005-06.

Baker, P., McKay, S. and E. Symons (1990), "The Simulation of Indirect Tax Reforms: The IFS Simulation Program for Indirect Taxes (SPIT)", IFS Working Paper Series, W90/11, Institute for Fiscal Studies.

Ballard, C. A., D. Fullerton, J.B. Shoven, and J. Whalley (1985), A General Equilibrium Model for Tax Policy Evaluation. University of Chicago Press, Chicago.

Ballentine, J. G. and I. Eris (1975), “On the General Equilibrium Analysis of Tax Incidence”, Journal of Political Economy, 83 (June 1975): 633-44.

Barna, T. (1945), Redistribution of Incomes through Public Finance. Oxford University Press, Oxford.

Barrett, A. and C. Wall (2005), The Distributional Impact of Ireland's Indirect Tax System, A Study Prepared for the Combat Poverty Agency, Economic and Social Research Institute, 4 Burlington Road, Dublin 4, July.

Barro, R. J. (1974), “Are Government Bonds Net Wealth?” Journal of Political Economy, 82(6): 10951117.

Barthold, T. (1993), "How Should We Measure Distribution?" National Tax Journal, 35 (September 1993): 291-99.

Barzel, Y. (2002), A Theory of the State: Economic Rights, Legal Rights, and the Scope of the State, Cambridge University Press, Cambridge.

Bentley. P., D.J. Collins, and N.T. Drane (1974), "The incidence of Australian taxation", Economic Record, 50:489-509. 
Berglas E. (1971), "Income Tax and the Distribution of Income: an International Comparison" in Public Finance/Finances Publiques, 26: 532-545.

Bibi S. and J. Duclos (2007), "Poverty-decreasing indirect tax reforms: Evidence from Tunisia," International Tax and Public Finance, Springer, 14(2) (April): 165-190.

Bird, R. (1980), "Income Redistribution Through the Fiscal System: The Limits of Knowledge", The American Economic Review, Papers and Proceedings of the Ninety-Second Annual Meeting of the American Economic Association, 70(2): 77-81.

Bishop, G. A. (1966), "Income Redistribution in the Framework of National Income Accounts", National Tax Journal, 19: 378-90.

Blundell, R., P. Pashardes and G. Weber (1993), "What do we learn about Consumer Demand Patterns from Micro Data?, American Economic Review 83(3): 570-97.

Boadway R. and M. Keen (2000), "Redistribution", in A.B. Atkinson and F. Bourguignon, Handbook of Income Distribution, 1: 677-789, North Holland.

Bordt, M., G.J. Cameron, S.F. Gribble, B.B. Murphy, G.T. Rowe and M.C. Wolfson (1990), "The Social Policy Simulation Database and Model: An Integrated Tool for Tax/Transfer Policy Analysis", Canadian Tax Journal, 38(1): 48-65.

Bosi, P., M. Baldini and D. Mantovani (1997), "Indirect Taxes" in Sutherland H. (Ed.) EUROMOD: A European Benefit-Tax Model and Social Integration: Preparatory Study Final Report. Cambridge: Department of Applied Economics.

Bradbury, B. (ed) (1990), "Tax-Benefit Models and Microsimulation Methods”, SPRC Reports and Proceedings No 87, Social Policy Research Centre, University of New South Wales, Sydney.

Bradford, D. F. (1978), "Factor Prices May Be Constant but Factor Returns Are Not", Economics Letters I (November 1978): 199-203.

Bramley, G. and M. Evans (2000), "Getting the Smaller Picture: Small-Area Analysis of Public Expenditure Incidence and Deprivation in Three English Cities”, Fiscal Studies 21(2): 231-267.

Break, G. F. (1974), "The Incidence and Economic Effects of Taxation”, In The Economics of Public Finance, edited by A. S. Blinder, R. M. Solow, G. F. Break, P. O. Steiner, and D. Netzer. The Brookings Institution, Washington, D.C.

Brennan, G. (1976), “The Distributional Implications of Public Goods”, Econometrica 44(2): 391-399.

Burniaux, J.-M., T.-T. Dang, D. Fore, M.F. Förster, M. Mira d'Ercole, and H. Oxley (1998), "Income Distribution and Poverty in Selected OECD Countries", Economics Department Working Paper No. 189, OECD.

Callan, T., J. Walsh, and K. Coleman (2004), "Budget 2005: Impact on Income Distribution and Relative Income Poverty", special article in the Quarterly Economic Commentary (December). ESRI, Dublin.

Canberra Group (2001), Final Report and Recommendations, The Canberra Group: Expert Group on Household Income Statistics, Ottawa. 
Cantillon B., R. Van Dam, K. Van den Bosch, and B. Van Hoorebeeck (2003), "The impact of the reference period on measures of household income from surveys", CSB-berichten, Centre for Social Policy, Antwerp.

Cartter, A. M.. (1955), The Redistribution of Income in Post War Britain. Yale University Press, New Haven.

Caspersen E. and G. Metcalf (1994), "Is a Value Added Tax Regressive? Annual versus Lifetime Incidence Measures”, National Tax Journal 47: 731-46.

Castro-Leal, F., J. Dayton, L. Demery, and K. Mehra (1999), "Public Social Spending in Africa: Do the Poor Benefit?” The World Bank Research Observer 14(1): 49-72.

Central Statistical Office (1990), "The Effects of Taxes and Benefits on Household Income, 1987”, Economic Trends 439(May): 84-118.

Central Statistics Office (2004), County Incomes and Regional GDP 2001, CSO, Dublin.

Chamberlain, A. and G. Prante (2007), "Who Pays Taxes and Who Receives Government Spending? An Analysis of Federal, State and Local Tax and Spending Distributions, 1991-2004", Tax Foundation Working Paper 1, Tax Foundation.

Citro, C. F. and E.A. Hanushek (eds), (1991), Improving Information for Social Policy Decisions: The Uses of Microsimulation Modeling. Technical Papers, Vol II, National Research Council. The National Academies Press.

Congressional Budget Office (CBO) (1988), The Effects of Tax Reform on Tax Expenditures, U.S. Government Printing Office, Washington, DC.

Congressional Budget Office (2004), Effective Federal Tax Rates under Current Law: 2001-2014.

Conrad, A. (1954), "Redistribution Through Government Budgets in the United States, 1950" in Income Redistribution and Social Policy, edited by A. T. Peacock, 178-267, Jonathan Cape, London.

Cowell, F. (1995), Measuring inequality. Prentice Hall, London.

Cowen, T. (ed.) (1988), The Theory of Market Failure: A Critical Examination. George Mason University Press, Fairfax.

Crane, S. E. (1983), "Interpreting the Distribution of Government Expenditures in Budget Incidence Studies", National Tax Journal 36(2): 243-247.

Creedy, J. (1999), Indirect tax reforms in Australia: the welfare effects on different demographic groups, Australian Economic Papers, December, pp367-392

Creedy, J. (2001), "Indirect tax reform and the role of exemptions," Fiscal Studies, 22(4) (December): 457486.

Creedy, J. (2002), "The GST and vertical, horizontal and re-ranking effects of indirect taxation in Australia", Australian Economic Review, 35(4): 380-390. 
Cronin, J.-A. (1999), “U.S. Treasury Distributional Analysis Methodology”, U.S. Treasury Office of Tax Analysis Paper 85, U.S. Department of Treasury, Washington, D.C.

Davies, J., F. St-Hilaire and J. Whalley (1984), "Some Calculations of Lifetime Tax Incidence", American Economic Review 74(September): 633-49.

Davoodi, H. R., E.R. Tiongson and S.S. Asawanuchit (2003), "How Useful Are Benefit Incidence Analyses of Public Education and Health Spending?", IMF Working Paper WP/03/226. International Monetary Fund, Washington, D.C.

Decoster, A. (1995), “A Microsimulation Model for Belgian Indirect Taxes - With a Carbon/Energy Tax Illustration”, Tijdschrift voor Economie en Management, 40(2): 133-156.

Decoster A, K. De Swerdt and G. Verbist (2007), "Indirect taxes and social policy: Distributional impact of alternative financing of social security”, Discussion Paper Series 07.11, K.U.Leuven, CES, 25 pages.

Decoster, A. and G. Van Camp (2001), "Redistributive Effects of the Shift from Personal Income Taxes to Indirect Taxes: Belgium 1988-93", Fiscal Studies, 22: 79-106.

Decoster, A., E. Schokkaert and G. Van Camp (1997), "Is redistribution through indirect taxes equitable", European Economic Review, 41(3-5): 599-608.

Deleeck H., K. Van den Bosch and L. De Lathouwer (1992), Poverty and Adequacy of Social Security in the EC. A Comparative Analysis, Avebury, Aldershot.

Demery, L. (2002), Analyzing the Incidence of Public Spending. World Bank, Washington, D.C.

Denzau, A. T. and R.J. Mackay (1976), "Benefit Shares and Majority Voting”, The American Economic Review, 66(1): 69-76.

Deussing, Marie-Anne (2003), "Federal Taxes and Transfers Across Canada: Impact on Families", Working Paper 2003-21, Department of Finance, Canada.

Devarajan, S. and S.I. Hossain (1995), "The Combined Incidence of Taxes and Public Expenditures in the Philippines”, World Bank Policy Research Working Paper WPS 1543, World Bank, Washington, D.C.

Diamond, P. A. (1970), "Incidence of an Interest Income Tax", Journal of Economic Theory 2(September): 211-24.

Dilnot, A. and A.S. Duncan (1992), "Lone mother, family credit and paid work", Fiscal Studies, 13(1):121.

Dixon, P.B. and G.A. Meagher (1990), "ORANI Simulations of the Effects of Replacing the Wholesale Tax with a Goods and Services Tax", Paper presented at a conference on Taxation Issues on the 1990s, Monash University, 25-28 June 1991.

Dodge, D.A. (1975), "Impact of Tax, Transfer, and Expenditure Policies of Government on the Distribution of Personal Income in Canada" The Review of Income and Wealth, 21(1): 1-52. 
Donaldson, D. and J.A. Weymark (1980), "A single parameter generalization of the Gini indices of inequality”. Journal of Economic Theory, 22: 67-86.

Duclos, J-Y. (1993), "Progressivity, redistribution, and equity, with application to the British tax and benefit system", Public Finance, 48(3), 350-65.

Duncan, A.S. (1990), “A Microsimulation Model of Labour Supply for UK tax reforms”, University of Konstanz Discussion Paper Series II, No 153.

DYNAMOD Technical Paper Series, Various Issues, NATSEM. University of Canberra, Canberra.

Eardley T., J. Bradshaw, J. Ditch, I. Gough and P. Whiteford (1996), Social assistance in OECD countries: Synthesis Report. HMSO, London.

Entin, S. J. (2004), “Tax Incidence, Tax Burden, and Tax Shifting: Who Really Pays the Tax?" IRET Policy Bulletin No. 88, Institute for Research on the Economics of Taxation, Washington, D.C.

EUROMOD (1997), A European Benefit-Tax Model and Social Integration: Preparatory Study Final Report, Department of Applied Economics, Cambridge.

Eurostat (1996), Comparison in real terms of the aggregates of ESA, results for 1994. Eurostat, Luxembourg.

Eurostat (1996), The European Community Household Panel (ECHP): Survey methodology and implementation, Theme 3, Series E. Eurostat, Luxembourg.

Eurostat (1997), Household Budget Surveys in the EU, Methodology and Recommendations for harmonization. Eurostat, Luxembourg.

Eurostat (2004), Structure of Taxation Systems in the European Union. Eurostat, Luxembourg.

Feenberg, D., A. Mitrusi and J. Poterba (1996), "Distributional Effects of Adopting a National Retail Sales Tax", Tax Policy and the Economy 10.

Feldstein, M. S. (1974a), "Incidence of a Capital Income Tax in a Growing Economy with Variable Savings Rates", Review of Economic Studies 41 (October 1974a): 505-13.

Feldstein, M. S. (1974b), "Tax Incidence in a Growing Economy with Variable Factor Supply", Quarterly Journal of Economics 88 (November 1974b): 551-73.

Feldstein, M. S. (1976), “On the Theory of Tax Reform”, Journal of Public Economics 6 (July-August 1976): 77-104.

Feldstein, M. S. (1999), "Tax Avoidance and the Deadweight Loss of the Income Tax", Review of Economics and Statistics 81(4): 674-680.

Feldstein, M. S. and P. Bacchetta (1989), "National Saving and International Investment”, National Bureau of Economic Research Working Paper No. 3164.

Fianna Fàil and the Progressive Democrats (2002), An Agreed Programme for Government Between Fianna Fàil and the Progressive Democrats. Available through

$<\mathrm{http} / / /$ www.taoiseach.gov.ie/index.asp?locID=512\&docID=794>. 
Fifty-State Property Tax Comparison Study (2005), Minnesota Taxpayers Association, St. Paul, Minnesota.

Fisher, R C. (2007), State and Local Public Finance, Third Edition. Thompson Southwestern, Mason, OH.

Formby, J. P., T.G. Seaks W.J. and Smith (1981), “A Comparison of Two New Measures of Tax Progressivity”, Economic Journal, 91 (December): 1015-9.

Förster, M. and M. Mira D’Ercole (2005), “Income Distribution and Poverty in OECD Countries in the Second Half of the 1990s", OECD Social, Employment and Migration Working Papers No. 22. OECD, Paris.

Friedman, M. (1957), A Theory of the Consumption Function, Princeton University Press, Princeton.

Fry, B. R. and R.F. Winters (1970), "The Politics of Redistribution”, The American Political Science Review. 64: 508-522.

Fullerton, D. and G.E. Metcalf (2002), "Tax Incidence" in Handbook of Public Economics, Volume 4, edited by A.J. Auerbach and M. Feldstein, pp1787-872, Amsterdam: Elsevier Science.

Fullerton, D. and D. Rogers (1991), "Lifetime versus Annual Perspectives on Tax Incidence" National Tax Journal 44: 277-87

Fullerton, D. and D. Rogers (1996), "Lifetime Effects of Fundamental Tax Reform," in Economic Effects of Fundamental Tax Reform, ed. H. Aaron and W. Gale (Washington: Brookings Institution).

Fullerton, D. and D.L. Rogers (1993), Who Bears the Lifetime Tax Burden? The Brookings Institution, Washington, D.C.

Gallagher, P. (1990), “Australian Microsimulation Models: An Overview” in Bradbury, B. (ed), "TaxBenefit Models and Microsimulation Methods", SPRC Reports and Proceedings No 87, Social Policy Research Centre, University of New South Wales, Sydney.

Galper, H., R. Lucke and E. Toder (1988), “A General Equilibrium Analysis of Tax Reform” in Uneasy Compromise: Problems of a Hybrid Income-Consumption Tax, edited by H. J. Aaron, H. Galper, and J. A. Pechman. The Brookings Institution, Washington, D.C.

García, J., J.M. Labeaga and A. López (1997), “Análisis microeconómico de los efectos de cambios en el sistema impositivo y de prestaciones sociales", Moneda y Crédito, 204: 67-104.

Gardiner K., J. Hills, V. Lechene and H. Sutherland (1995), "The effects of differences in housing and health care systems on international comparisons of income distribution", STICERD, WSP/110.

Garfinkel I., L. Rainwater and T. Smeeding (2004), "Welfare state expenditures and the redistribution of well-being: children, elders, and others in comparative perspective". Paper prepared for the APPAM (Association for Public Policy Analysis and Management) Conference, 29 October 2004, Atlanta.

Garfinkel I., L. Rainwater and T. Smeeding (2006), "A Re-examination of Welfare State and Inequality in Rich Nations: How In-Kind Transfers and Indirect Taxes Change the Story", Journal of Policy Analysis and Management, 25(4), 897-919. 
Gemmell, N. (1985), "The Incidence of Government Expenditure and Redistribution in the United Kingdom", Econometrica 52(207): 335-344.

Giles, C. and J. McRae (1995), "TAXBEN: the IFS microsimulation tax and benefit model”, WP95/19, Institute for Fiscal Studies, London.

Gillespie, I. (1965), "Effect of Public Expenditures on the Distribution of Income" in Essays in Fiscal Federalism, edited by R. A. Musgrave. The Brookings Institution, Washington, D.C.

Gillespie, I. (1966), The Incidence of Taxes and Public Expenditures in the Canadian Economy, Studies of the Royal Commission on Taxation no. 2: 6-11, Queen's Printer, Ottawa.

Glennerster, H. (2006), "Tibor Barna: The Redistributive Impact of Taxes and Social Policies in the U.K.: 1937-2005”, Center for Analysis of Social Exclusion (CASE) Paper 115, London School of Economics, Center for Social Exclusion, London.

Grady, P. (1990), "The Distributional Impact of the Federal Tax and Transfer Changes Introduced since 1984”, Canadian Tax Journal, 38(2): 286-297.

Gravelle, J. G. and K. Smetters (1998), "Who Bears the Burden of the Corporate Tax (and Why)? The Open Economy Case", Congressional Budget Office Technical Paper 1998-1, U.S. Congressional Budget Office, Washington, D.C.

Greene, K. V., W.G. Neenan and C.D. Scott (1976), "Fiscal Incidence in the Washington Metropolitan Area", Land Economics 52(1): 13-31.

Hamilton, B. W. (1975), “Zoning and Property Taxation in a System of Local Governments”, Urban Studies 12 (June 1975): 205-11.

Hamilton, B. W. (1976), "Capitalization of Intrajurisdictional Differences in Local Tax Prices", American Economic Review 66 (December 1976): 743-53.

Hammes, D. L. and D.T. Wills (1987), "Public Debt, Interest and Fiscal Incidence", Review of Income and Wealth 33(4): 439-442.

Hancock, R. and H. Sutherland (ed.) (1992), Microsimulation Models for Public Policy Analysis: New Fountiers, STICERD, London School of Economics, London.

Hansen, Alicia (2004), "Lotteries and State Fiscal Policy", Tax Foundation Background Paper No. 46, Tax Foundation, Washington, D.C.

Harberger, A C. (1962), "The Incidence of the Corporate Income Tax", Journal of Political Economy, 70 (June 1962): 215-40.

Harberger, A C. (1964), "Taxation, Resource Allocation, and Welfare," in The Role of Direct and Indirect Taxes in the Federal Revenue System, edited by J. F. Due, 25-70, Princeton University Press, New Jersey.

Harberger, A C. (1980), "Vignettes on the World Capital Market", American Economic Review, 70 (May 1980): 331-37. 
Harding A., R. Lloyd and N. Warren (2004), "The distribution of taxes and government benefits in Australia", Paper presented at the conference on the distributional effects of government spending and taxation, The Levy Economics Institute, October.

Harding A., R. Lloyd and N. Warren (2006), "Moving beyond traditional cash measures of economic wellbeing: including indirect benefits and indirect taxes", National Centre For Social and Economic Modelling, Discussion Paper no. 61, University of Canberra, November.

Harding, A., R. Lloyd and N. Warren (2005), "GST and the changing incidence of Australian taxes: 199495 to 2001-02", eJournal of Tax Research, 3(1): 114-145

Harding, A., Lloyd R. and N. Warren (2007), "Moving Beyond Traditional Cash Measures of Economic Well-Being: The Impact on Income Inequality of Including Non-Cash Benefits and Indirect Taxes", in The Distributional Effects of Government Spending and Taxation (ABA festschrift for Tony Atkinson) edited by J. Micklewright and T. Jenkins, 84-102, OUP, Oxford.

Heady C., T. Mitrakos and P. Tsakloglou (2001), "The distributional impact of social transfers in the EU: Evidence from the ECHP”, Fiscal Studies 22: 547-565.

Helliweg, O. (1990), "Current Status and Developments in Microsimulation Software", in SOFTSTAT'89, edited by F. Faulbaum, R. Haux, and K.-H. Jockel. Verlag, Stuttgart.

Helliweg, O. (1990), “The Overseas Experience with Microsimulation Models", in Bradbury, B. (ed), "Tax-Benefit Models and Microsimulation Methods", SPRC Reports and Proceedings No 87, 5-28, Social Policy Research Centre, University of New South Wales, Sydney.

Henry, K. R. and J.S. Wright (1992), "PRISMOD development, database and methodology", Paper presented at the Australasian Economic Modelling Conference, 2-5 September.

Hewitt, D. P. (1987), “The Benefit Incidence of Consumption Public Goods”, Public Finance Review 15(2): 138-165.

Hughes, G. (2000), "The Cost and Distribution of Tax Expenditure on Occupational Pensions in Ireland", in Economic Problems of Ireland in Europe: Thirty-first Geary Lecture. ESRI, Dublin.

Hughes, G. and D. Watson (2005), Pensioners' Incomes and Replacement Rates in 2000, ESRI, Dublin.

IFS Green Budget (2007), 2007, Institute for Fiscal Studies, London.

Immervoll H., C. O’Donoghue and H. Sutherland (1999), “An Introduction to EUROMOD”, EUROMOD Working Paper EM0/99.

Immervoll, H. and C. O’Donoghue (2001), "Towards a Multi-Purpose Framework for Tax-Benefit Microsimulation: A Discussion by Reference to EUROMOD, a European Tax-Benefit Model", EUROMOD Working Paper no. 2/01, Department of Applied Economics, University of Cambridge. Available through $<$ http://www.econ.cam.ac.uk/dae/mu/emod.htm $>$

Immervoll, H., H. Levy, C. Lietz, D. Mantovani, C. O’Donoghue, H. Sutherland and G. Verbis (2005), "Household Incomes and Redistribution in the European Union: Quantifying the Equalising Properties of Taxes and Benefits", EUROMOD Working Paper No. EM9/05, United Kingdom: University of Essex Institute for Social and Economic Research. 
Impact of State and Local Taxes: Issues and Options for States, Center on Budget and Policy Priorities, Washington, DC.

Johannes, T. A., T. Akwi and E. Anzah (2006), "The Distributive Impact of Fiscal Policy in Cameroon: Tax and Benefit Incidence", PMMA Working Paper 2006-16, Poverty and Economic Policy (PEP) Research Network, Québec, Canada.

Jones, F. (2007), “The Effects of Taxes and Benefits on Household Income, 2005-06”, Social Analysis and Reporting Division Office, Office of National Statistics (United Kingdom). Available from $<$ www.ons.gov.uk>

Kaiser H. and P.B. Spahn (1989), "On the efficiency and distributive justice of consumption taxes: a study on VAT in West Germany”, Journal of Economics, 2: 199-218.

Kakwani, N C. (1977b), "Measurement of Tax Progressivity: An International Comparison", Economic Journal, 87 (March): 71-80.

Kakwani, N. C. (1977a), “Applications of Lorenz Curves in Economic Analysis”, Econometrica 45(3): 719-727.

Kakwani, N.C. (1984), "On the Measurement of Tax Progressivity and Redistributive Effect of Taxes with Application to Horizontal and Vertical Equity", in Economic Inequality: Measurement and Policy, Advances in Econometrics, Vol. 3,, edited by R. L. Basmann and G. F. Rhodes. JAI Press, Greenwich CT.

Kakwani, N.C. and N. Podder (1976), "Efficient Estimation of the Lorenz Curve and Associated Inequality Measures from Grouped Observations", Econometrica, 44 (January): 137-48.

Kansas Fiscal Facts, Twelfth Edition (2005), Kansas Legislative Research Department, Topeka, Kansas.

Kansas Tax Facts: A Reference Booklet on State and Local Taxes, Seventh Edition (2000), Kansas Legislative Research Department, Topeka, Kansas.

Kaplanoglou, G. (2004), "Household Consumption Patterns, Indirect Tax Structures and Implications for Indirect Tax Harmonisation: A Three Country Perspective", Economic and Social Review, 35(1): 83108.

Kaplanoglou, G. and D.M. Newbery (2003), "Indirect taxation in Greece: Evaluation and possible reform", International Tax and Public Finance, 10(5) 511-533.

Katz, M. L. and S.R. Harvey (1985), “Tax Analysis in an Oligopoly Model”, Public Finance Quarterly 13 (January 1985): 3-19.

Kay, J.A., C.N. Morris and N.A. Warren (1980), “Tax, Benefits and the Incentive to Seek Work”, Fiscal Studies, 1(4): 8-25.

Kendrick, M. S. (1930), "Public Expenditure; A Neglected Consideration in Tax Incidence Theory", The American Economic Review, 20(2): 226-30.

Kesselman, J. and R. Cheung (2004), "Tax Incidence, Progressivity, and Inequality in Canada”, Canadian Tax Journal, 52(3):709-89 
Khetan, C.P. and S.N. Poddar (1976), "Measurement of Income Tax Progression in a Growing Economy: The Canadian Experience", Canadian Journal of Economics, 9 (November): 613-29.

Kiefer, D. W. (1984), “Distributional Tax Progressivity Indexes”, National Tax Journal, 37 (December): 497-513.

Kienzle, E C. (1982), "Post-Fisc Distributions of Income: Measuring Progressivity with Application to the United States", Public Finance Quarterly 10(3): 355-68.

King, A., W. Foster and I. Manning (1990), "Microsimulation at NIESIR: Development and Applications". Paper presented at the Social Policy Research Centre workshop on Tax-Benefit Models and Microsimulation Methods, University of New South Wales, 1 June.

King, M.A. (1983), "Welfare Analysis of tax reforms using household data", Journal of Public Economics, $21,183-214$.

King, M.A. (1986), “The Empirical Analysis of Tax Reforms," NBER Working Papers 1996, National Bureau of Economic Research, Inc.

Kotlikoff, L. J. and L.H. Summers (1987), “Tax Incidence”, In Handbook of Public Economics, edited by A. J. Auerbach and M. Feldstein. North- Holland, Amsterdam.

Krupp H.J. (1986), "Potential and Limitations of Microsimulation Models" in Microanalytic Simulation Models to Support Social and Financial Policy, edited by G. Orcutt, J. Merz and H. Quinke, 31-43. Elsevier Science Publishers, North-Holland.

Krzyzaniak, M. (1967), "Long-Run Burden of a General Tax on Profits in a Neoclassical World", Public Finance (1967): 472-91.

Labert, S., R. Percival, D. Schofield and S. Paul (1994), “An Introduction to STINMOD: A Static Microsimulation Model”, STINMOD Technical Paper No 1, October, NATSEM.

Lambert, P. J. (1993), The Distribution and Redistribution of Income: a Mathematical Analysis (2nd ed.). Manchester University Press, Manchester.

Lambert, S and N. Warren (1999), 'STINMOD-STATAX: a comprehensive model of the incidence of taxes and transfers in Australia', Technical Paper No. 16, National Centre for Social and Economic Modelling, University of Canberra, Canberra.

Lanjouw, P, and M. Ravallion (1998), "Benefit Incidence and the Timing of Program Capture", World Bank 1998 Poverty Assessment for India. World Bank, Washington, D.C.

Lanjouw, P., M. Pradhan, F. Saadah, H. Sayed, and R. Sparrow (2001), "Poverty, Education and Health in Indonesia: Who Benefits from Public Spending?" World Bank Policy Research Working Paper No. 2739, World Bank, Washington, D.C.

Lasswell, H. D. (1936), Politics: Who Gets What, When, How. McGraw-Hill, New York.

Layte, R., H. Russell and S. McCoy (2002), The Economics and Marketing of Tobacco: An Overview of the Existing Published Evidence. ESRI, Dublin. 
Layte, R., C.T. Whelan, B. Maitre, B. Gannon, B. Nolan, D. Watson and J. Williams ( 2003), Monitoring Poverty Trends in Ireland: Results from the 2001 Living in Ireland Survey. Policy Research Series 51, ESRI, Dublin.

Leigh, A. (2005), "Deriving Long-Run Inequality Series from Tax Data", The Economic Record,. 81(255) S58-S70.

Liberati, P. (2001), “The Distributional Effects of Indirect Tax Changes in Italy," International Tax and Public Finance, Springer, 8(1) (January): 27-51.

Lyon, A.B. and R.M. Schwab (1991), "Consumption Taxes in a Life-Cycle Framework: Are Sin Taxes Regressive?" Review of Economics and Statistics (77): 389-406.

MacDonald, D A. (2004), Western States' Tax Burdens Fiscal Year 2002-2003: Initial State and Local Tax Burdens for Selected Western States, Revised. Economic and Statistical Unit, Utah State Tax Commission, Salt Lake City, Utah.

Madden, D. (1989), “Indirect Tax Reform in Ireland”, Economic and Social Review, 21(1): 27-47.

Madden, D. (1995), “An Analysis of Indirect Tax Reform in Ireland in the 1980s”, Fiscal Studies, 16: 1837.

Madden, D. (1996), "Marginal Tax Reform and the Specification of Consumer Demand Systems", Oxford Economic Papers, 48(4): 556-67.

Mantovani, D. and H. Sutherland (2003), "Social Indicators and other Income Statistics using the EUROMOD Baseline: a Comparison with Eurostat and National Statistics", EUROMOD Working Paper EM1/03.

Marical, F., M. Mira d'Ercole, M. Vaalavuo and G. Verbist ( 2006), "Publicly-provided Services and the Distribution of Resources François Marical, Marco Mira d'Ercole, Maria Vaalavuo and Gerlinde Verbist, OECD Social, Employment and Migration Working Paper 45 (DELSA/ELSA/WD/SEM(2006)14)

Martinez-Vazquez, J. (1982), "Fiscal Incidence at the Local Level”, Econometrica 50(5): 1207-1218.

Martinez-Vazquez, J. (2004), "The Impact of Fiscal Policy on the Poor: Fiscal Incidence Analysis", International Studies Program Working Paper Series 01-10, Georgia State University, Georgia.

Mazerov, M. (2002), "Developing the Capacity to Analyze the Distributional Impact of State and Local Tax”, State Tax Notes, 23(7), 18 February 2002.

McIntyre, R. S., R. Denk, N. Francis, M. Gardner, W. Gomaa, F. Hsu and R. Sims (2003), Who Pays?: A Distributional Analysis of the Tax Systems in All 50 States, 2nd Edition. Institute on Taxation and Economic Policy, Washington, DC.

McLure, C. E. and G.R. Zodrow (1987), "Treasury I and the Tax Reform Act of 1986: The Economics and Politics of Tax Reform", Journal of Economic Perspectives, 1 (Summer 1987): 37-58.

McLure, C. E. Jr. (1970), “Taxation, Substitution, and Industrial Location”, Journal of Political Economy 78 (January- February 1970): 112-32. 
McLure, C. E. Jr. (1971), “The Theory of Tax Incidence with Imperfect Factor Mobility” Finanzarchiv 30 (1971): 27-48.

McLure, C. E. Jr. (1975), "General Equilibrium Incidence Analysis: The Harberger Model after Ten Years”, Journal of Public Economics, 4 (February 1975): 125-61.

McLure, C. E. Jr. and G.R. Zodrow (1994), "The Study and Practice of Income Tax Policy" in Modern Public Finance, edited by J. M. Quigley and E. Smolensky. Harvard University Press, Cambridge, Mass..

Meagher, G.A. (1991), “The Incidence of Sales Tax Reform”, Paper presented at a conference of Taxation Issues in the 1990s, Monash University, 25-28 June 1991.

Menchik, P L. (1991), “The Distribution of Federal Expenditures”, National Tax Journal 44: 269-76.

Metcalf, G. (1993), “The Lifetime Incidence of State and Local Taxes: Measuring Changes During the 1980s," in Tax Progressivity and Income Inequality, ed. J. Slemrod (New York: Cambridge University Press).

Metcalf, G.E. (1997), “The National Sales Tax: Who Bears the Burden?”, Cato Policy Analysis No. 289, December, Cato Institute <http://www.cato.org/pubs/pas/pa-289.html $>$

Mieszkowski, P. (1967), “On the Theory of Tax Incidence”, Journal of Political Economy 75 (June 1967): $250-62$.

Mieszkowski, P. (1969), "Tax Incidence Analysis: The Effects of Taxes on the Distribution of Income", Journal of Economic Literature (December 1969): 1103-24.

Mieszkowski, P. (1972), “The Property Tax: An Excise Tax or a Profits Tax?” Journal of Public Economics 1 (April 1972): 73-96.

Minnesota Tax Incidence Study (2005), Tax Research Division, Minnesota Department of Revenue, St. Paul, MN.

Musgrave, R A. (1953), “General Equilibrium Aspects of Incidence Theory”, American Economic Review 43 (May 1953): 504-17.

Musgrave, R A. (1959), The Theory of Public Finance: A Study in Political Economy. McGraw-Hill, New York.

Musgrave, R A. (1974), Public Finance: Theory and Practice, McGraw-Hill, US.

Musgrave, R. and T. Thin (1986), "Income Tax Progression 1929-48" in Public Finance in a Democratic Society: Collected Papers of Richard A. Musgrave, edited by R. A. Musgrave. NYU Press, New York.

Musgrave, R.A. and T. Thin (1948), "Income Tax Progression, 1929-48”, Journal of Political Economy, 56 (December): 498-514.

Myck, M. (2000), “Fiscal Reforms Since May 1997”, The Institute for Fiscal Studies, Briefing Note No. 14

Nebraska Tax Burden Study (2002), Research Division, Nebraska Department of Revenue, Lincoln, NE. 
Newbery D.M.G. (1995), "The Distributional Impact of Price Changes in Hungary and in the United Kingdom", Economic Journal, 105: 847-863.

O'Donoghue, C, M. Baldini and D. Mantovani (2004), Modeling the Redistributive Impact of Indirect taxes in Europe: An Application of EUROMOD, EUROMOD Working paper EM7/01, Department of Applied Economics, University of Cambridge

OECD (2006), Revenue Statistics, OECD, Paris.

OECD (2004), Benefits and Wages, OECD Indicators. OECD, Paris.

ONS (2007), “The effects of taxes and benefits on household income, 2005-06", Office of National Statistics.UK.

Oregon Tax Incidence Model (2001), Oregon Legislative Revenue Office, Salem, OR.

Palme, M. (1996), "Income Distribution Effects of the Swedish 1991 Tax reform: An Analysis of a Microsimulation Using Generalised Kakwani decomposition", Journal of Policy Modeling, 18(4): 419-443.

Papadimitriou, D B. (2006), "Government Effects on the Distribution of Income: An Overview", Levy Economics Institute of Bard College Working Paper No. 442, Levy Economics Institute, Annandaleon-Hudson, New York.

Peacock, A, (ed) (1954), Income Distribution and Social Policy. Jonathan Cape, London.

Pechman, J. A. (1985), Who Paid the Taxes, 1966-85? The Brookings Institution, Washington, D.C.

Pechman, J. A. (1990), “The Future of the Income Tax”, American Economic Review 80 (March 1990): 120.

Pechman, J. A. and B.A. Okner (1974), Who Bears the Tax Burden? The Brookings Institution, Washington, D.C.

Philpotts, G. (1986), “Public Good Benefit Attribution”, Public Finance Quarterly, 14: 313-328.

Piketty, T. and E. Saez (2006), "How Progressive is the U.S. Federal Tax System? A Historical and International Perspective", NBER Working Paper No. 12404, National Bureau of Economic Research, Cambridge, Mass..

Poterba, J. M. (1989), "Lifetime Incidence and the Distributional Burden of Excise Taxes", American Economic Review, 79(2): 325-30.

Poterba, J.M. (1991), “Is the Gasoline Tax Regressive?” Tax Policy and the Economy 5 (1991): 145-64.

Poterba, J.M. (1993), "Who Bears the Lifetime Tax Burden? A Book Review”, National Tax Journal 44(4): 539-42.

Prest, A. R. (1955), “Statistical Calculations of Tax Burdens”, Economica, 22(87): 234-45.

PRISMOD (1992), Press Release No 2, 11 March 1992, The Treasury, Canberra. 
Pudney, S. (1992), "Dynamic Simulation of Pensioners' Incomes: Methodological Issues and a Design for a Computer Model for Great Britain", Microsimulation Policy Modeling Unit, Paper No MPMU 9201, University of Cambridge, Cambridge.

Randolph, W C. (2006), "International Burdens of the Corporate Income Tax", Congressional Budget Office Working Paper 2006-09, U.S. Congressional Budget Office, Washington, D.C.

Redmond G, H. Sutherland and M. Wilson (1998), The Arithmetic of Tax and Social Security Reform: A User's Guide to Microsimulation Methods and Analysis. Cambridge University Press, Cambridge.

Revenue Commissioners (2005), Effective Tax Rates of Top 400 Earners: Report for the Tax Year 2001. Available through www.finance.gov.ie.

Reynolds, M. and E. Smolensky (1974), “The Post-Fisc Distribution: 1961 and 1970 Compared”, National Tax Journal, 27: 515-530.

Reynolds, M. and E. Smolensky (1977a), Public Expenditures, Taxes, and the Distribution of Income: The United States, 1950, 1961, 1970, Academic Press, New York.

Reynolds, M. and E. Smolensky (1977b), "Post Fisc Distributions of Income in 1950, 1961, 1970”, Public Finance Quarterly, 5 (October): 419-38.

Ruggeri G.C. and K. Bluck (1990), "On the Incidence of the Manufacturers' Sales Tax and the Goods and Services Tax" Canadian Public Policy, 16(4): 359-73.

Ruggeri, G.C. (1993), "On the Measurement of Sales Tax Incidence in the Presence of Transfers" Public Finance, 48(1) 132-37.

Ruggeri, G.C., D. Van Wart and R. Howard (1994), "The Redistributional Impact of Taxation in Canada" Canadian Tax Journal, 42(2): 417-51.

Ruggles, P. and M. O’Higgins (1981), “The Distribution of Public Expenditure Among Households in the United States", Review of Income and Wealth, 27(2): 137-64.

Ryan, M. (1994), "What Future for Payroll Taxes in Australia?", Paper presented to the Conference of Economists. Surfers Paradise, September.

Sah, R.J. (1983), "How much redistribution is possible through commodity taxes?" Journal of Public Economics, 20: 89-101.

Scutella, R. (1997), "Calculating the Final Incidence of Australian Indirect Taxes", Melbourne Institute of Applied Economic and Social Research Working Paper No 18/97.

Scutella, R. (1999), “The Final Incidence of Australian Indirect Taxes”, Australian Economic Review, 32(4): 349-68.

Selden, M. T, and M.J. Wasylenko (1992), “Benefit Incidence Analysis in Developing Countries”, Policy Research Public Economics Working Papers WPS 1015, World Bank, Washington, D.C.

Sen, A. (1973), On economic inequality. New York: Norton. 
Shahe E. M. and J.E. Stiglitz (2005), "On Selective Indirect Tax Reform in Developing Countries", Journal of Public Economics 89: 599-623.

Shirazi, N. S, M. Ilyas and M. Ahmad (2002), "Redistributive Effects of Public Expenditures in the Urban and Rural Areas of Pakistan", South Asia Economic Journal, 3(1): 69-76.

Shoven, J. B. (1976), "The Incidence and Efficiency Effects of Taxes on Income from Capital”, Journal of Political Economy, 84 (December 1976): 1261-83.

Slemrod, J. (1983), “A General Equilibrium Model of Taxation with Endogenous Financial Behavior" in Behavioral Simulation Methods in Tax Policy Analysis, edited by M. S. Feldstein. University of Chicago Press, Chicago.

Slemrod, J. (1988), "Effect of Taxation with International Capital Mobility" in Uneasy Compromise: Problems of a Hybrid Income-Consumption Tax, edited by H. J. Aaron, H. Galper, and J. A. Pechman. The Brookings Institution, Washington, D.C.

Smeeding T. and A. Grodner (2000), "Changing Income Inequality in OECD Countries: Updated Results from the Luxembourg Income Study (LIS)", LIS Working Paper, No 252, Luxembourg Income Study.

State Tax Study Commissions (2004), National Conference of State Legislatures, Washington, DC.

Stern, N. (1990), “Uniformity versus selectivity in indirect taxation”, Economics and Politics, 2: 83-108.

Steuerle, C. E. (1995), "Incentives, Disincentives, and Efficiency Issues," in Distributional Analysis of Tax Policy, edited by D. F. Bradford. Brookings Institution, Washington D.C..

Steuerle, C. E. (2003), “Can the Progressivity of Tax Changes be Measured in Isolation?" Tax Notes September 1, 2003: 1187-8.

STINMOD Technical Paper Series, Various Issues, NATSEM, University of Canberra, Canberra.

Suits, D. B. (1977), “Measurement of Tax Progressivity”. American Economic Review 67(4): 747-752.

Summers, L. H. (1981a), "Capital Taxation and Capital Accumulation in a Life Cycle Growth Model”, American Economic Review 71 (September): 533-44.

Summers, L H. (1981b), “Taxation and Corporate Investment: A q-Theory Approach", Brookings Papers on Economic Activity, 67-127, The Brookings Institution, Washington, D.C.

Sutherland H. (2000), "EUROMOD”, in Microsimulation in Government Policy and Forecasting, edited by A. Gupta and V. Kapur, 575-580, Elsevier.

Sutherland, H. (ed.) (2001), Final Report. EUROMOD: An integrated European benefit-tax model, EUROMOD Working Paper no. 9/01, Department of Applied Economics, University of Cambridge. Available through $<$ http://www.econ.cam.ac.uk/dae/mu/emod.htm $>$

Symons, E. and N.A. Warren (1996), "Modeling Consumer Behavioural Response to Commodity Tax Reforms in Microsimulation Models", in Microsimulation and Public Policy, edited by A. Harding, 149-176, North-Holland, Amsterdam. 
Tax Exemptions and Tax Incidence (2005), Office of the Comptroller, Austin, TX.

Tax Foundation (1957), "The Tax Burden in Relation to National Income and Product", Tax Foundation Research Aid No. 4, Tax Foundation, Washington, D.C.

Tax Foundation (1960), “Allocation of the Tax Burden by Income Class", Tax Foundation Project Note No. 45, Tax Foundation, Washington, D.C.

Tax Foundation (1981), “Allocating Tax Burdens and Government Benefits by Income Class, 1972-73 and 1977”, Tax Foundation Government Finance Brief No. 31, Tax Foundation, Washington, D.C.

Tax Foundation (1989), “Tax Burden by Income Class, 1986-1987”, Tax Foundation Special Report. Tax Foundation, Washington, D.C.

Tax Foundation (1967a), “Allocating Tax Burdens and Government Benefits by Income Class”, Tax Foundation Government Finance Brief No. 8, Tax Foundation, Washington, D.C.

Tax Foundation (1967b), "Tax Burdens and Benefits of Government Expenditures By Income Class, 1961 and 1965", Washington, D.C.

Tax Rates and Tax Burdens in the District of Columbia: A Nationwide Comparison, 2004, 2005. Government of the District of Columbia, Washington, DC.

Tsakloglou P. and T. Mitrakos (1998), "On the distributional impact of excise duties: Evidence from Greece”, Public Finance/Finances Publiques, 53: 78-101.

Tucker, R. S. (1953), "The Distribution of Government Burdens and Benefits”, American Economic Review, 43(2): 518-534.

U.S. Congressional Budget Office (2001), "Effective Federal Tax Rates, 1979-1997”, Congressional Budget Office. U.S. Government Printing Office, Washington, D.C.

Utah Household Tax Burdens (2001), Available through

$<$ http://www.tax.utah.gov/esu/burdens/hhburden_2001.html $>$.

Vandendorpe, A. L. and A.F. Friedlaender (1976), "Differential Incidence in the Presence of Initial Distorting Taxes", Journal of Public Economics, 6 (October 1976): 205-29.

Verbist G. (2004), "Redistributive Effect and Progressivity of Income Taxes: An International Comparison across the EU using EUROMOD”, EUROMOD Working Paper EM5/04.

Verbist G. (2005), "Replacement incomes and Taxes in the EU: An International Comparison using EUROMOD”, EUROMOD Working Paper No. EM2/05.

Verbist, G. (2002), An Inquiry into the Redistributive Effect of Personal Income Taxes in Belgium, UFSIA, Antwerp, May.

Vermaeten, A., I. Gillespie and F. Vermaeten (1995), "Who Paid the Taxes in Canada, 1951-1988?," Canadian Public Policy / Analyse de Politiques, 21(3) (Sep): 317-343.

Vermaeten, F. W.I. Gillespie and A. Vermaeten (1994), "Tax Incidence in Canada" Canadian Tax Journal $42(2) 348-416$, at 353-54. 
Wagstaff A. and E. van Doorslaer (2001), "What Makes the Personal Income Tax Progressive? A Comparative Analysis for Fifteen OECD Countries", in International Tax and Public Finance, 8(3): 299-316.

Warren, N. A. (1979), “Australian Tax Incidence in 1975-76:Some Preliminary Results”, Australian Economic Review, 3rd Quarter, 19-28.

Warren, N. A. (1983), Measuring Tax Incidence with Special Reference to Australia, Unpublished Ph.D. Dissertation, University of N.S.W.. Sydney, Australia.

Warren, N. A. (1985a), "Quantifying the Distributional Effects of Alternative Tax Options - A Report of Progress", EPAC Discussion Paper Series 85/3, Economic Planning Advisory Council, Canberra.

Warren, N. A. (1985b), "Simulating the First Round Effects of Changes in the Tax Mix Using the STATAX Program and the 1984 HES Unit Record Data". Paper presented at the National Tax Summit, Canberra.

Warren, N. A. (1986), "The Distributional Impact of Changing the Tax Mix in Australia: Some Preliminary Findings", in J. G. Head, Changing the Tax Mix in Australia, Australian Tax Research Foundation, Sydney, Conference Series No. 6, pp. 115-132.

Warren, N. A. (1987), Distributional Impact of Changes in the Tax Mix in Australia, ATRF Research Study No. 6, Australian Tax Research Foundation, pp x+123.

Warren, N. A. (1989a), "The Spatial Incidence of Selected N.S.W. Taxes in 1985-86", in Review of the State Tax System Volume 2: Commissioned Studies, NSW Tax Task Force, 1989, 63-159.

Warren, N. A. (1989b), "Changes in Australian Tax Incidence Between 1975-76 and 1984-85”, in Australian Tax Reform in Retrospect and Prospect, edited by J.G.Head, Australian Tax Research Foundation, Conference Series No. 8, 445-478.

Warren, N. A. (1991), The Changing Incidence of Federal Indirect Taxes: 1975-76 to 1988-89, Background Paper 13, Economic Planning Advisory Council, 77, AGPS, Canberra.

Warren, N. A. (1997), "Recent Trends in Taxation in Australia and their Impact on Australian Tax Incidence", in Taxation Towards 2000, edited by J. G. Head and R. Krever, Conference Series 19, Australian Tax Research Foundation.

Warren, N. A. (1998), Tax Facts and Tax Reform, Australian Tax Research Foundation, Research Study 31, Sydney.

Warren, N. A. (2004), Ta: Fact Fiction and Reform, Australian Tax Research Foundation, Research Study 41 , Sydney.

Whiteford, P. (1985), A family's needs: equivalence scales, poverty and social security, Research Paper No. 27, Department of Social Security, Canberra.

Wisconsin Tax Incidence Study (2004), Division of Research and Policy, Wisconsin Department of Revenue, Madison, WI.

Wolff, E. N. and A. Zacharias (2004), "An Overall Assessment of the Distributional Consequences of Government Spending and Taxation in the U.S., 1989 and 2000", Paper presented at the Levy 
Economics Institute conference The Distributional Effects of Government Spending and Taxation, October 15-16, Bard College, Annandale-on-Hudson, New York.

Wong, J. D. (2006), Kansas Tax Incidence Study: Who Pays Kansas Individual Income, Residential Property, and Retail Sales Taxes, Prepared for the Kansas Department of revenue by the Kansas Public Finance Center, Hugo Wall School of Urban and Public Affairs, Wichita State University, March.

Wong, J. D. and N.M. Snyder (1995), "Distributional Impact of Tax Policy Changes" in Report of the Governor's Tax Equity Task Force. Topeka, KS, Kansas.

Wulf, Luc De. (1975), "Fiscal Incidence Studies in Developing Countries: Survey and Critique", International Monetary Fund Staff Papers, 22: 61-131.

Yitzhaki, S. (1983), “On an extension of the Gini index", International Economic Review, 24: 614-28. 


\section{OECD SOCIAL, EMPLOYMENT AND MIGRATION WORKING PAPERS}

Most recent releases are:

No. 63 GLOBALISATION AND LABOUR MARKETS: POLICY ISUES ARISING FROM THE EMERGENCE OF CHINA AND INDIA

David T. Coe (2007)

No. 62 MIGRANT WOMEN INTO WORK - WHAT IS WORKING?

Alexandra Heron (2007) Forthcoming

No. 61 ADDRESSING LABOUR MARKET DUALITY IN KOREA

David Grubb, Jae-Kap Lee and Peter Tergeist (2007)

No. 60 LIFE-EXPECTANCY RISK AND PENSIONS: WHO BEARS THE BURDEN? Edward Whitehouse (2007)

No. 59 AUDIT DU SERVICE PUBLIC DE L'EMPLOI AU LUXEMBOURG David Grubb (2007)

No. 58 TRENDS IN INTERNATIONAL MIGRATION FLOWS AND STOCKS, 1975-2005

B. Lindsay Lowell (2007)

No.57 UNAUTHORIZED MIGRANTS IN THE UNITED STATES: ESTIMATES, METHODS, AND CHARACTERISTICS (2007)

Jeffrey Passel

No. 56 LA POLITIQUE MIGRATOIRE FRANÇAISE À UN TOURNANT (2007)

Martine Durand et Georges Lemaître

No. 55 THE UNIFICATION OF THE SOCIAL INSURANCE CONTRIBUTION COLLECTION SYSTEM IN KOREA (2007)

Sinchul Jang

No. 54 ASSESSING THE IMPACT OF LABOUR MARKET POLICIES ON PRODUCTIVITY: A DIFFERENCEIN-DIFFERENCES APPROACH (2007)

Andrea Bassanini and Danielle Venn

No. 53 PENSION REFORM IN CHINA: PROGRESS AND PROSPECTS (2007)

Felix Salditt, Peter Whiteford and Willem Adema

No. 52 INTERGENERATIONAL TRANSMISSION OF DISADVANTAGE: MOBILITY OR IMMOBILITY ACROSS GENERATIONS? A REVIEW OF THE EVIDENCE FOR OECD COUNTRIES (2007) Anna Christina d'Addio

No. 51 WHAT WORKS BEST IN REDUCING CHILD POVERTY: A BENEFIT OR WORK STRATEGY? (2007) Peter Whiteford and Willem Adema

No. 50 THE LABOUR MARKET INTEGRATION OF IMMIGRANTS IN DENMARK (2007) Thomas Liebig

No. 49 THE LABOUR MARKET INTEGRATION OF IMMIGRANTS IN AUSTRALIA (2007) Thomas Liebig

No. 48 THE INTEGRATION OF IMMIGRANTS INTO THE LABOUR MARKET: THE CASE OF SWEDEN (2007) Georges Lemaître

No. 47 THE LABOUR MARKET INTEGRATION OF IMMIGRANTS IN GERMANY (2007) Thomas Liebig

Recent available working papers can be found on the OECD website: http://www.oecd.org/els/workingpapers.

Other series of working papers available from the OECD include: OECD HEALTH WORKING PAPERS 


\section{RECENT RELATED OECD PUBLICATIONS:}

JOBS FOR YOUTH: NEW ZEALAND (2008)

JOBS FOR YOUTH: NETHERLANDS (2008)

A PROFILE OF IMMIGRANT POPULATIONS IN THE $21^{\text {ST }}$ CENTURY (2008)

MODERNISING SOCIAL POLICY FOR THE NEW LIFE COURSE (2007)

BABIES AND BOSSES - Reconciling Work and Family Life: A Synthesis of Findings for OECD Countries (2007)

BENEFITS AND WAGES - OECD Indicators (2007)

JOBS FOR IMMIGRANTS (VOL. 1): LABOUR MARKET INTEGRATION IN AUSTRALIA, DENMARK, GERMANY AND SWEDEN (2007)

FACING THE FUTURE: KOREA'S FAMILY, PENSION AND HEALTH POLICY CHALLENGES (2007)

PENSIONS AT A GLANCE: Public policies across OECD countries (2007)

JOBS FOR YOUTH: KOREA (2007)

JOBS FOR YOUTH: BELGIUM (2007)

JOBS FOR YOUTH: SPAIN (2007)

JOBS FOR YOUTH: SLOVAK REPUBLIC (2007)

OECD EMPLOYMENT OUTLOOK (2007)

INTERNATIONAL MIGRATION OUTLOOK - 2007 Edition

SICKNESS, DISABILITY AND WORK: BREAKING THE BARRIERS (VOL. 2) - AUSTRALIA, LUXEMBOURG, SPAIN AND THE UNITED KINGDOM (2007)

WOMEN AND MEN IN OECD COUNTRIES (2006)

SOCIETY AT A GLANCE: OECD Social Indicators (2006)

PENSIONS PANORAMA: RETIREMENT INCOME SYSTEMS IN 53 COUNTRIES

(joint publication with the World Bank) (2006)

SICKNESS, DISABILITY AND WORK: BREAKING THE BARRIERS (VOL. 1) - NORWAY, POLAND AND

SWITZERLAND (2006)

AGEING AND EMPLOYMENT POLICIES: LIVE LONGER, WORK LONGER (2006)

BABIES AND BOSSES: Reconciling Work and Family Life, Volume 4 Canada, Finland, Sweden and the United Kingdom (2005)

EXTENDING OPPORTUNITIES - How active social policy can benefit us all (2005)

SERIES OF AGEING AND EMPLOYMENT POLICIES

AUSTRALIA (2005), AUSTRIA (2005), CANADA (2005), DENMARK (2005), FRANCE (2005, GERMANY (2005

For a full list, consult the OECD On-Line Bookstore at www.oecd.org 